\title{
"Para seguir cortes y servir a los reyes de la tierra". Las vidas cruzadas de Aldana y Arias Montano a raíz de un nuevo documento ${ }^{1}$
}

\author{
Adalid Nievas Rojas \\ Universitat de Girona \\ adalid_nievas@hotmail.com
}

Recepción: 24/05/2021, Aceptación: 05/07/2021, Publicación: 22/12/2021

\begin{abstract}
Resumen
El estudio presenta y da noticia del hallazgo de un manuscrito inédito y desconocido hasta la fecha, describiendo y dando cuenta detallada de sus diferentes partes. Seguidamente, se contextualiza y explica el contenido y significado de uno de los elementos que lo componen: una carta desconocida de Benito Arias Montano a Francisco de Aldana. Para ello se realiza una reconstrucción precisa de las relaciones entre dos autores tan importantes en la historia política y la cultura española del siglo XVI como el sabio frexnense y el poeta hispanoflorentino, aportando, además, una gran cantidad de materiales de archivo inéditos y desconocidos.
\end{abstract}

Palabras clave

Benito Arias Montano; Francisco de Aldana; Felipe II; Monarquía Hispánica; manuscrito; cartas; documentos desconocidos.

\begin{abstract}
English Title. "Para seguir cortes y servir a los reyes de la tierra". The Interconnected Lives of Aldana and Arias Montano in the Light of a New Document.

This study presents and reports the discovery of an unpublished and previously unknown manuscript: a letter from Benito Arias Montano to Francisco de Aldana. In order to contextualize and explain it, the article offers a precise reconstruction of the relationships
\end{abstract}

1. Este trabajo se inscribe en el proyecto "Garcilaso de la Vega en Italia. Clasicismo horaciano" (2020-2023). Ministerio de Ciencia e Innovación. PID2019-107928GB-100. IP Eugenia Fosalba. 
between the wise polygraph born in Fregenal de la Sierra and the Hispano-Florentine poet, at the same time making use of a large number of other previously unknown archival material.

Keywords

Benito Arias Montano; Francisco de Aldana; Philip II; Hispanic Monarchy; Manuscript; Letters; Unknown Document.

\section{Nota previa}

Para dar al César lo que es del César y a Dios lo que es de Dios, debo explicar el origen del descubrimiento que hoy me complazco en presentar en estas páginas. El 7 de enero de 2017 recibí un inquietante correo electrónico de mi antiguo profesor de Literatura Medieval Rafael Ramos, que decía: "No tengo palabras para expresar lo que siento. Mire lo que he podido ver, pero que no puedo citar ni estudiar". El misterioso mensaje traía un archivo adjunto, una imagen, una reproducción fotográfica de lo que parecía, al menos por la miniatura visible, una carta manuscrita. Y así era. Nada más abrir el documento pude comprobar, atónito, que lo que mi corresponsal me acababa de enviar era una copia de una carta desconocida de don Fadrique de Toledo dirigida al capitán Francisco de Aldana. Gratísima era sin duda la noticia, ilusionante, prometedora, pero un dulce malum al fin y al cabo, pues enseguida comprendí el cariz amargo de las palabras de Ramos. Por lo visto, el 7 de diciembre de 2016, tan solo un mes antes de que me escribiera mi exprofesor, la casa de subastas británica Bloomsbury, a través de la gran casa Dreweats, había sacado a remate en su sala de Newbury (Donnington Priory) un manuscrito estimado entre dos mil y tres mil libras esterlinas titulado Breve raguaglio et historia dell'Almirante Don Ferdinando di Aldana (lote 80). El manuscrito no se vendió en esa ocasión, pero algunas webs ligadas al mundo de las subastas (Liveauctioneers.com o Invaluable.com, por 
ejemplo) que habían registrado la oferta del 7 de diciembre mantuvieron en sus catálogos la ficha informativa del lote, la cual incluía una sucinta descripción del documento y, lo que es más sorprendente, tres imágenes descargables probatorias del contenido: una del rótulo, perteneciente a las primeras hojas; otra de la escritura de la narración, también del inicio; y otra, la última, representativa del bloque final, la de la carta destinada a Aldana. He aquí, o allí, tan cerca y a la vez tan lejos, la certeza y la visión de un tesoro inalcanzable. Como dolorosamente comprobó Ramos cuando cayó en una de las webs mencionadas, la publicación en línea y permanente de imágenes de un manuscrito no vendido con noticias inéditas sobre Aldana suponía experimentar poco menos que los padecimientos de Tántalo. Podíamos ver, casi oler y tocar la delicia documental a través de la pantalla, mas inútilmente. De ahí que tanto Ramos, primero, como yo mismo, y mi maestra Eugenia Fosalba, después, intentáramos contactar varias veces con la casa de subastas, pero una política de alta privacidad y reserva se interponía siempre entre nosotros y el manuscrito. Nadie respondía a nuestras preguntas; nadie, siquiera, nos contestaba. "De los señores de Londres no sé nada. ¡Maldición!", me escribió Ramos, con el regusto de un triste desenlace, poco tiempo después de haber descargado sobre mis hombros la frustración derivada de un hallazgo inaccesible. Solo quedaba renunciar, o insistir esperando.

Así pues, durante tres años, por lo menos una vez al mes, he introducido en la barra de búsqueda de Google el título del manuscrito: Breve raguaglio et historia dell'Almirante Don Ferdinando di Aldana. Durante tres años, he conservado la esperanza de que el manuscrito de marras saliera de nuevo a subasta y a tiempo de comprarlo, pero los resultados nunca han variado: siempre las mismas entradas a la notificación, cada vez más pretérita, de la venta pública del 7 de diciembre de 2016, cuya caducidad hoy siguen exhibiendo algunas webs como una auténtica broma de mal gusto. Sin embargo, el pasado mes de noviembre, en uno de esos intentos ya rutinarios, automáticos y desidiosos, mi particular caza obtuvo de pronto, sin más, su anhelada captura. Entre los resultados de siempre, aparecía por fin uno nuevo, vinculado a una de las plataformas de Internet más conocidas del mundo para la venta y compra de libros: AbeBooks. Súbitamente, el manuscrito resurgía ante mis ojos y no en una subasta, sino como parte del catálogo de la librería londinense Mayfair Rare Books and Manuscripts, fundada en 2017 por el italiano Paolo Rimbaldi. Su descripción, más detallada que la que figuraba en el registro hecho por Bloomsbury en 2016, aseguraba que la sección final la conformaban cuatro cartas enviadas a Francisco de Aldana, entre ellas, una de "Benedictus Arias Montano, the famous scholar and editor of the multilingual Bible commissioned by King Philip II of Spain". Y para colmo estaba a la venta. Con el entusiasmo aún refrenado por un inevitable escepticismo, contacté directamente con la librería para averiguar si el manuscrito seguía disponible, tal y como indicaba la base de datos de AbeBooks y de su ramo español IberLibro. La respuesta, del propio Rimbaldi, llegó en pocas horas: "Dear Adalid, many thanks for your interest and the email, and yes the manuscript is available". In- 
mediatamente, di cuenta y razón de la buena nueva a Eugenia Fosalba, conocedora total de mis desvelos por encontrar el manuscrito y plenamente implicada en cada intento por recuperarlo. Y lo adquirimos. En consecuencia, puedo contar hoy aquí que desde el mes de diciembre de 2020 la Biblioteca del campus Barri Vell de la Universitat de Girona custodia un manuscrito sobre el linaje de los Aldana, cuyo valor se concentra especialmente en la recolecta final, donde se han transmitido hasta cuatro documentos (tres de ellos desconocidos) relacionados con el autor de la Carta para Arias Montano. "Si la epístola en verso no fuera para mí era digna de admiración de todos los buenos ingenios. Sea Dios bendito por sus dones y maravillas", le expresó el sabio de la Peña al Divino en agradecimiento al poema que le dedicara. Así se lee en el post scriptum de la carta de Montano conservada en el manuscrito, un impagable y precioso testimonio que hoy no estaría dando a conocer sin la confianza de Rafael Ramos y de Eugenia Fosalba. Vaya, pues, mi agradecimiento por delante.

\section{Descripción del manuscrito}

El manuscrito sobre papel del que doy noticia mide 280x195mm., y se halla encuadernado en becerro jaspeado. En el lomo consta el título en oro: HIS / ALDA / NA. Se cuentan hasta 56 folios no numerados, incluyendo la hoja de cortesía del principio, las dos del final y una portadilla con título manuscrito posterior al siglo xviII. Se aprecian algunos bordes picoteados, ligeras manchas marginales de agua en las primeras hojas y algo de pardeamiento leve debido a la tinta, que es siempre marrón. La escritura del manuscrito es a línea tirada de hasta treinta renglones, en letra humanística cursiva, con nombres ocasionalmente en mayúscula, toda ejecutada por una sola mano excepto en dos de las cuatro adendas finales. Las fechas de elaboración del manuscrito (pudiera haber más de un periodo de redacción) se sitúan hacia mediados del siglo xvir. La lengua de los textos es las más de las veces italiana, en ocasiones traducción de pasajes españoles, aunque se pueden encontrar fragmentos y cartas en latín y en castellano. La composición material del documento debió de realizarse en Italia, posiblemente en Milán, pues, según el librero Paolo Rimbaldi, él mismo adquirió el códice en la librería milanesa Il Polifilo, en el ańo 2008. Nótese que el dato es sustancioso, ya que nos permite acercarnos a las raíces del manuscrito, sacándolo satisfactoriamente de la órbita inglesa. De la información contenida en el manuscrito muy poco se puede obtener sobre el autor, salvo que se trata de alguien que ha pasado cincuenta siete ańos de su vida en el ejercicio de las armas y que ha alcanzado, en la vejez, la calma necesaria para emplearse en el estudio de las letras. ${ }^{2}$

2. "[...] ben che per insino adesso habbia cinquanta sette anni di continuo essercitio militare, nel qual tempo mi sono a molti incontri trovato, ben che hora io viva più con Pallade e con Mi- 
Tres secciones claramente diferenciadas conforman el manuscrito, como se colige del título moderno: Breve ragguaglio ed historia di Don Ferdinando d'Aldana, primo dei Maldonadi, istorie ricavate dei vari libri, e documenti che trattano della famiglia Perez d'Aldana Maldonado. La primera parte refiere la historia, recogida en multitud de crónicas, nobiliarios y composiciones, tanto antiguas como contemporáneas, del fundador del apellido Maldonado, Hernán (o Nuño) Pérez de Aldana, almirante del rey don Alonso III el Magno, y su desafío con el duque de Normandía, Guillermo, sobrino del rey don Felipe de Francia. ${ }^{3}$ El duelo, estipulado para reparar un agravio ocurrido durante la fiesta de la $\mathrm{Na}$ tividad de Nuestra Señora en la iglesia de Montserrat, se resolvió sobre campo francés con la victoria de Pérez de Aldana, que reclamó por recompensa y premio aquello que sería blasón y divisa de sus descendientes: cinco de las ocho flores de lis que el rey don Felipe ostentaba en su escudo de armas. "Je te les donne, mais maldonnées", le respondió el monarca con disgusto, es decir, contra su voluntad. A partir de entonces, Hernán Pérez de Aldana mudó este último apellido por el de Maldonado, tomándolo de la frase del rey de Francia, y comenzó a lucir por armas cinco lirios de plata en campo de gules. Según se indica en el propio manuscrito, el compilador sigue una versión de Pedro de Gracia Dei, rey de armas y cronista de los Reyes Católicos entre los años 1493 y 1500, aproximadamente: "Arme cavate per Gratia Dei, coronista maggiore delle Spagne". ${ }^{4}$

nerva che con Marte...", en Biblioteca del campus Barri Vell de la Universitat de Girona, Ms. Aldana, s. f. Véase más adelante la cita completa, en la referencia número 12 del comentario a la segunda sección del manuscrito.

3. Baste con citar aquí los textos, con sus inequívocos tintes de leyenda (y sus consecuentes variaciones) de Zapata (1566: 139v), Molina (c. 1620: 48v), Flórez de Ocariz (1676: 4), Piferrer (1857: 48-51) y Rivas (1874).

4. Justo en el folio anterior — una hoja preliminar casi en blanco- se apunta únicamente esta advertencia: "Questo si trova scritto nel libro intitolato Il coronista maggiore delle Spagne" (la cursiva es mía). Biagio Aldimari señala lo mismo al tratar sobre la familia Aldana Maldonado, tanto en su Memorie historiche di diverse famiglie nobili como en su Historia genealogica della famiglia Carafa: "Ernan Perez de Aldana, che fù Ammirante Maggiore del Mare, e pigliò anco il cognome di Maldonato, per certo accidente, che si narra dal Cronista maggiore della Spagna" (Aldimari 1691a: 193; 1691b: 369). Lo cierto es que no se conoce ninguna obra de Gracia Dei con ese título, que es, por otra parte, un título imposible (acaso se corresponda con "La corónica de España", conservada en la Boston Public Library, fondo Ticknor, D. 10, aunque por no haber tenido acceso al documento me ha sido imposible desmentir o corroborar este supuesto), así que es muy probable que la afirmación del compilador de nuestro manuscrito y de Aldimari se base en la rúbrica de alguna de las muchas obras manuscritas atribuidas a Gracia Dei que proliferaron durante los siglos XVI, XVII y XVIII, donde se le designa a veces como "Chronista", "Choronista de los señores Reyes Católicos" o "Coronista del emperador Carlos V" (véase, a modo de ejemplo, Biblioteca Nacional de España, ms. 628, ms. 3231 y ms. 18053). Podría pensarse también que la denominación concreta de "cronista mayor de España" resulta extemporánea para Gracia Dei, ya que solo se aplica a la figura de José Pellicer Ossau y Tovar en la portada de su Bibliotheca formada de los libros i obras publicas (Valencia, por Gerónimo Vilagrasa, 1671) y en la Noticia de la gran casa de los Marqueses de Villafranca de fray Jerónimo de Sosa (1676: 322 y 358), título oficialmente otorgado por Felipe IV al linajista e historiador aragonés el 20 de agosto de 1640 (Pellicer Ossau y 
La segunda parte, titulada "Luoghi di Historie di varij libri che trattano Aldana e Maldonado, che è tutta una", constituye una especie de antología de pasajes extraídos de distintas fuentes impresas en los que se recogen las menciones y hazañas de los más afamados personajes de ambas casas. Se trata, pues, de una recopilación de fragmentos, espigados de acá y allá, acumulados sin un orden manifiesto, en ocasiones separados por un trazo y en otras por un espacio en blanco. En la mayoría de los casos, el compilador del manuscrito cita la procedencia exacta de los textos mediante referencias específicas, como el título o el autor de la obra, el año o el lugar de impresión, o el capítulo, parte o número de folio en que se encuentra el pasaje copiado. Por ello es relativamente fácil advertir que no todos los textos son un traslado ad litteram de la fuente original. A veces, el copista extracta algunas de las narraciones que sigue; interpone en el curso del relato comentarios de su bagaje y opiniones; o adiciona datos, nombres y apellidos del linaje del que se ocupa cuando las crónicas que maneja los descuidan o ignoran.

Trece son en total las obras de las que echa mano el compilador del manuscrito en la segunda sección, sin contar un trabajo del historiador Pedro Barrantes Maldonado al que se alude en un apunte suelto intercalado entre dos citas. ${ }^{5}$

Tovar, 1671: 24r-25v). Esta consideración permite conjeturar que el compilador del manuscrito reunió los materiales heráldicos e históricos sobre las casas de Aldana y Maldonado hacia mediados del siglo XviI. En cualquier caso, conviene aclarar que la única narración conocida de Pedro de Gracia Dei sobre el origen del linaje de los Maldonado (transmitida en un documento del siglo xv en poder, al menos hasta 1953, de don José Maldonado y Fernández del Torco) no coincide con la versión que trae nuestro manuscrito (al protagonista de los hechos se le llama Suero de Aldana en vez de Hernán Pérez de Aldana; y su incidente con el duque de Normandía no tiene lugar en el santuario de Montserrat, sino en Santiago de Compostela ante las cenizas del apóstol); véase, a este respecto, García Carrafa (1921: 28-29), Maldonado y Cocat (1953: 469-470) y Mogrobejo (1998: 402-403 y 406-407). No hay que pasar por alto que la obra de Gracia Dei se ha transmitido de forma muy variopinta en el conjunto de la tradición textual, incluso con varios títulos. Precisamente, sus obras heráldicas están muy deturpadas, es decir, son las que han sufrido mayores versiones, reelaboraciones y refundiciones, sobre todo por copiarse en siglos posteriores a la actividad del autor. Generalmente, suelen mezclarse las coplas de Pedro de Gracia Dei con fragmentos de obras de otros genealogistas, bien en prosa o en verso, lo que ha dado lugar a numerosas confusiones y falsas atribuciones. De ahí que la referencia a Gracia Dei como posible fuente de la primera parte de nuestro manuscrito resulte, cuando menos, problemática. Coplas ahijadas al tratadista gallego acerca del origen del apellido Maldonado se localizan en las diferentes tradiciones manuscritas de sus Blasones de las armas e insignias de los mejores y más principales linajes de Castilla (sin ánimo de agotar aquí la totalidad de los testimonios, remito solo a algunos casos representativos en la Biblioteca Nacional de Espańa: ms. 3231, f. 78r; ms. 3449, f. 12v; ms. 3564, f. 79v; ms. 3769, f. 43r-v; ms. 5911, f. 15r; ms. 6175, f. 265r; ms. 7864, f. 18v; ms. 18045, f. 44r). Para una aproximación a la biografía y la obra de Pedro de Gracia Dei véanse las recientes y fecundas investigaciones de Natalia Anaís Mangas Navarro (2020a; 2020b; 2020c), a quien agradezco su amabilidad y precisión a la hora de atender a mis preguntas.

5. La información de la nota es interesantíma, ya que permite establecer el terminus ad quo de la composición del manuscrito: “[B]arrantes Maldonado d'Aldana scrisse molto copiosamente delle famiglie di Spagna, e particularmente della casa e familia del Duca di Medina Sidonia, e questo nel anno 1636, e di questo authore ne fanno ne fanno [sic] gran stima e conto, et he citato 
Paso a continuación a enumerarlas, según el orden en que aparecen: ${ }^{6}$

1) Primera y segunda parte de las Grandezas y cosas notables de España, de Pedro de Medina y Diego Pérez de Mesa (Alcalá de Henares, en casa de Juan Gracián, 1595), ff. 277v-278r. Se copia la descripción de la villa de San Sebastián. El compilador ańade al final una referencia a Francisco de Aldana que no se halla en el impreso.

2) Delle historie del mondo, de Cesare Campana (Venecia, appresso Giorgio Angelieri, 1591). Aunque no lo indique, el compilador sigue siempre la edición de Pavía (appresso Andrea Viani, 1602). Se copian de manera discontinua fragmentos de las pp. 172, 632, 646, 647, 651 657, 660 y 666, relativos a la participación de Francisco de Aldana en la segunda campaña de Levante (1572) y en la jornada de África (1578). Antes de citar a Campana, el autor del manuscrito recuerda la crónica del capitán Luis de Ojeda como ejemplo de relato verídico. ${ }^{7}$

3) Historia del descubrimiento y conquista del Perú, de Agustín de Zárate (Amberes, en casa de Martín Nucio, 1555). El compilador no apunta ningún dato sobre esta fuente. El pasaje recogido es una traducción al italiano distinta de la que hizo Alfonso de Ulloa (Le historie del sig. Agostino di Zarate, Venecia, appresso Gabriel Giolito de' Ferrari, 1563). El texto parece basarse en la edición de Sevilla (en casa de Alonso Escribano, 1577), y pertenece a los capítulos XVI y XVII del libro VI, donde se narran acciones de Diego Maldonado y Lorenzo de Aldana en el contexto de la gran rebelión de los encomenderos del Perú (1544-1548) contra el emperador Carlos V.

4) La Historia d'Italia, de Francesco Guicciardini (Florencia, appresso Lorenzo Torrentino, 1561). No se indican datos de edición, pero los fragmentos están extraídos de la de Venecia (appresso Domenico Farri, 1587), concretamente de los ff. 373r y 374v, en los que se refiere la actuación del coronel Maldonado en el epílogo de la Guerra de la Liga de Cambrai (1516-1517).

5) Illustrivm scriptorvm religionis societatis lesv catalogvs, de Pedro de Ribadeneira (Amberes, apud Ioannem Moretum, 1608). El compilador usa la edición de Lyon (apud Ioannem Pillehotte, 1609) para copiar de las pp. 124-126 la nota biobibliográfica del teólogo sevillano Juan Maldonado, autor de unos Commentarii in quatuor evangelia (Mussiponti [i.e.: Pont a Mousson], apud Stephanum Mercatorem, 1596).

6) Supplemento e quinto volume dell'Historie del mondo [...], qval segve la terza parte da lui aggiunta alla notabile Historia di M. Giovanni Tarchagnotta, de Mambri-

dal Villegas nel Flos sanctorum". Para la obra de Barrantes sobre las familias Aldana y Maldonado véase la edición del ms. 17996 de la Biblioteca Nacional de España llevada a cabo por Martín Nieto y Miranda Díaz (2010).

6. La utilización material de las fuentes es irregular, esto es, pueden hallarse, copiados o traducidos, varios fragmentos de una misma obra en distintas partes de la segunda sección del manuscrito. Por tanto, el orden de la relación de las obras que entran en juego atiende solo a su primera aparición, y no a las sucesivas de algunos casos.

7. "Comentario que trata de la infeliz jornada que el rey Don Sebastián hizo en la Berbería el año de 1578 , donde se quenta mui en particular todo lo que allí sucedió con la muerte del rey y otras cosas dignas de admiración y de ser savidas, el qual comentario hizo el capitán Luis de Ojeda, que allí se halló presente a quasi todo", en Biblioteca Nacional de España, ms. 12866, ff. 1r-87v. 
no Roseo da Fabriano (Venecia, per gli heredi di Francesco [et] Michele Tramezzini, c. 1583). El fragmento copiado se encuentra en el f. 299r, donde se relata la defensa y pérdida de La Goleta en 1574, en la que participó el capitán Diego Maldonado. El compilador ańade la noticia de su muerte, que queda sin referir en el impreso.

7) "Entrando in consiglio [en blanco] et lo Aldana, concluserò che per prendere Manfredonia era necesario mettere sopra il monte l'artiglierie, altramente non si potea sperar buon successo di quella impresa, e ciò fatto Manfredonia si rese, che senza questa impresa era dificile prosseguir l'acquisto del Regno di Napoli". No he logrado identificar la procedencia de este pasaje, pero es indudable que trata sobre la actuación del coronel Gonzalo de Aldana en la campaña de 1509 del segundo virrey español de Nápoles, Juan de Aragón, conde Ribagorza, para la toma de Manfredonia y otras plazas adriáticas en poder de Venecia. ${ }^{8}$

8) Chrónica de las tres Órdenes y Cauallerías de Sanctiago, Calatraua y Alcántara, de Francisco Rades de Andrada (Toledo, en casa de Iuan de Ayala, 1572). Los fragmentos que provienen de esta obra son traslación al italiano, a veces con añadidos del compilador, de varios lugares de la "Chrónica de Alcántara" (y no de la "Chrónica de Calatraua", como se afirma por error en la segunda referencia extraída), localizables entre los capítulos 3 y 35. Los pasajes traducidos son aquellos en los que aparecen menciones a miembros de las casas de Aldana y Maldonado, entre los que se encuentran también comendadores de la Orden. Cuantitativamente hablando, la crónica de Rades es la mayor fuente de información del conjunto del manuscrito, hasta el punto de constituir prácticamente un bloque aparte, con título propio: "Alcune brevi annotazioni tolte dalle Croniche delle Croci d'Alcantara et Calatrava, ove si trata di Casa Aldana, il cui libro è in stampa appresso di me". ${ }^{9}$

9) La vita dell'invittissimo Imperator Carlo Qvinto, de Alfonso de Ulloa (Venecia, appresso Vincenzo Valgrisi, 1560). No se indica edición. El compilador recoge las menciones a un "Francesco Maldonado" (al que le ańade "d'Aldana"), al conquistador del Incario Lorenzo de Aldana y a Diego Maldonado, rector del Cuzco. Más adelante el copista lee, erróneamente, "Francesco d'Aldana", en vez de "Francés d'Alava”, como puede verse en la p. 679 de la primera edición.

8. Ver Aldimari (1691a: 194; 1691b: 370). También se puede localizar a Gonzalo de Aldana en la defensa de Manfredonia en la guerra hispano-francesa de 1528; ver Real Academia de la Historia, Colección Salazar y Castro, ms. A-42, ff. 300r-302v (Nápoles, 30 de abril-1 de mayo de 1528: carta de Juan Pérez a Carlos V con noticias sobre el bloqueo y sitio de Nápoles); y Serricchio (1988: 228-229).

9. Mi lectura de este comentario es que el traductor y antólogo poseyó un volumen del impreso en castellano de la Chrónica de Rades de Andrada. No se conoce traducción ni reimpresión de la trilogía de las Órdenes Militares convenida entre Francisco Rades y Juan de Ayala, así que, a mi juicio, una hipótesis que baraje la posibilidad de que el compilador del manuscrito fue también impresor de esta obra debe descartarse sin paliativos. Por otra parte, no parece muy lógico pensar que el impresor toledano Juan de Ayala Cano (sobrino homónimo del también impresor Juan de Ayala), activo entre 1560 y 1578 , sea la misma persona que reunió los materiales de este manuscrito de mediados del siglo Xvir. Para la difusión de la trilogía de Rades, "un clásico de presencia casi obligada entre los anaqueles de la elite privilegiada de la Modernidad", véase Gómez Vozmediano (2016: 226-235). 
10) Segunda parte de la Historia Pontifical y Cathólica, de Gonzalo de Illescas (Salamanca, en casa de Vincente Portonarijs, 1573). El compilador acude a los ff. 116, 127, 149, 401, 402, 452 y 471 para copiar las noticias sobre Diego Arias Maldonado y Rodrigo Maldonado e incluir las de Bernardo de Aldana y Francisco de Aldana. Por lo que respecta a este último, el copista ańade de su cosecha —equivocándose — la referencia al poeta soldado (nótese la correcta falta del dato en el f. 471r-v de la edición salmantina), que no participó en la campańa contra el Turco de 1571, sino en la de 1572, aunque se muestra conocedor de su experiencia en Flandes y en los frentes de guerra italianos.

11) Dell'vnione del Regno di Portogallo alla Corona di Castiglia, de Girolamo Franchi di Conestaggio (Génova, appresso Girolamo Bartoli, 1585). Los pasajes se extraen de la edición de Milán (appresso Giovanni Battista Bidelli, 1616), aunque no haya especificaciones por parte del compilador y se afirme, por descuido, que la fuente es el historiador Cesare Campana. Se copian fragmentos de las pp. 29, 55 y 73 de dicha edición, donde se refiere la participación de Francisco de Aldana en la jornada de África junto al rey don Sebastián.

12) Istoria de' suoi tempi, de Giovanni Battista Adriani (Florencia, nella stamperia de i Giunti, 1583). El texto copiado proviene de la p. 344, donde se recuerda la actuación -deshonrosa, según el cronista florentino- de Bernardo de Aldana en la defensa de Lipova durante la guerra de Hungría (1552). La postura crítica de Giovanni Battista Adriani suscita en el compilador una "breve consideratione" que acaba convirtiéndose en el único intersticio del manuscrito por donde se filtra su personalidad: "Queste e molte altre cose si potrebbono soggiungere, ma rimettendomi sempre a ogni miglior più sano giuditio che non he il mio, ben che per insino adesso ben che per insino adesso [sic] habbia cinquanta sette anni di continuo essercitio militare, nel qual tempo mi sono a molti incontri trovato, ben che hora io viva più con Pallade e con Minerva che con Marte godendo più tosto per l'impossibilità delle forze trattar dolcemente con le nove sorelle per insino che l'innesorabil Parcha recida questo labilissimo filo, e tenue stame men sofferente che'l fil d'aragne per poi volarmene tutto searco al sem del eterna verità, la ve tutte le cose sono aperte, e chiare, per essere ivi totalmente squarciato il vel delle nostre fosche ignoranze".

13) Libro llamado Silua de varia leción, de Pedro Mejía (Sevilla, por Dominico de Robertis, 1540). El compilador maneja la edición veneciana de la quinta parte, ampliada y revisada por Francesco Sansovino: Della Selva di varia lettione di Pietro Messia (presso Girolamo Polo, 1574). Se siguen los ff. 422r y 425r, donde se rememoran algunas actuaciones de Lorenzo de Aldana en las Indias en 1539.

La tercera y última parte de la colección manuscrita la componen cuatro fuentes primarias de información relacionadas directamente con Francisco de Aldana o con su familia; cuatro documentos que se anexan al final como pruebas del alto reconocimiento de que gozaron los Aldana y de sus indiscutibles lazos políticos e intelectuales. El primero de ellos es el único que nos era conocido: una copia del diploma de la concesión en 1571 a Hernando y Cosme de Aldana por parte de Francisco I de Médici, príncipe de Florencia, de una pensión anual y vitalicia de trescientos escudos de oro con motivo de la muerte de su padre, 
Antonio de Aldana. ${ }^{10}$ La letra del testimonio es claramente distinta a la del compilador del manuscrito.

El segundo documento es una copia, esta sí debida a la misma mano que trabaja en el resto del manuscrito, de una carta de don Fadrique de Toledo dirigida a Francisco de Aldana, con fecha de 20 de febrero de 1577, escrita durante el confinamiento del futuro IV duque de Alba en Tordesillas.

El tercer texto es una traslación al italiano de una carta, redactada originalmente en portugués, del rey don Sebastián a su embajador en España Cristóbal de Moura, fechada a 10 de diciembre de 1577, sobre los méritos y merecimientos del capitán Aldana. ${ }^{11}$ La letra coincide con la del compilador del manuscrito.

El cuarto documento es, a todas luces, el más valioso y sorprendente del conjunto manuscrito: una carta autógrafa y desconocida de Benito Arias Montano a Francisco de Aldana, firmada en Madrid el 30 de enero de 1578.

El carácter privado y receptor de estos cuatro documentos finales para Hernando, Cosme y, sobre todo, Francisco de Aldana induce a pensar que su cadena de transmisión tuvo que originarse por fuerza en alguna persona próxima al hispanoflorentino, destinatario de las cartas del rey de Portugal, don Fadrique de Toledo y Benito Arias Montano. Resulta tentador, por arriesgado que parezca, ver a Cosme de Aldana, en su afanosa búsqueda de información y textos de su hermano "por varias partes", ${ }^{12}$ como recuperador y merecido adquiriente de esas misivas que el poeta debió dejar a buen recaudo en Madrid antes de partir hacia África a principios de julio de $1578 .{ }^{13} \mathrm{Al}$ fin y al cabo, no puede obviarse que la última ciudad en la que residió Cosme de Aldana y donde tuvo lugar la mayor parte de su actividad literaria y editorial fue Milán, la misma ciudad en la que, como se ha

10. La cédula, expedida en latín, tiene fecha de 4 de febrero de 1570 , pero se basa en el calendario florentino (cuyo año nuevo empezaba el 25 de marzo, día de la Encarnación), así que debe sumarse una unidad para reducir dicha fecha a la era cristiana (1571). Existe otra copia en Archivio di Stato di Firenze, Deputazione sopra la nobilità e la cittadinanza, XII, 5. Véase, además, Nievas Rojas (2020: 202-203).

11. Se conserva una copia de una carta de don Sebastián a Cristóbal de Moura, posterior a esta (del 21 de enero de 1578), en la que el rey transmite su deseo de que Aldana participe en la inminente expedición africana; véase Archivo General de Simancas, Estado, leg. 395, f. 54. Para Elias L. Rivers (1953: 556), el documento del archivo simanquino representa "la primera de muchas peticiones hechas por don Sebastián", pero la carta de nuestro manuscrito demuestra que las maniobras para asegurar los servicios de Aldana habían comenzado un mes antes. Cabe añadir que la misiva, aunque fuera despachada a Cristóbal de Moura, indicaba expresamente que se mostrase al hispanoflorentino: "Questa lettera la mostrerete al capitano Aldana". Todo apunta a que el poeta se quedó con la carta original, lo que explicaría que en ni en el legajo 394 ni en el 395 del fondo Estado del Archivo General de Simancas (Negociación de Portugal) se conserve copia alguna.

12. Véase la dedicatoria de Cosme a Felipe II, en Aldana (1593: f. A3v).

13. "[...] os vernéis a Madrid, para que desde allí os encaminéis donde el rey [don Sebastián] estuviere, que lo uno y lo otro holgaré sea con la brevedad posible", carta de Felipe II a Aldana, 30 de junio de 1578, en Archivo General de Simancas, Estado, leg. 395, f. 74 (cit. en Rivers 1953: 557-558). 
dicho antes, pudiera haberse elaborado el manuscrito. ${ }^{14}$ Es tarea ardua, cuando no imposible, descifrar el modo en que llegaron esos documentos a las manos del compilador, aunque podría aventurarse la posibilidad de que este tuviera algún tipo de parentesco con Cosme y que se tratara, por tanto, de un Aldana, justo heredero de una riquísima documentación que no dudaría en incorporar a su trabajo de recopilación de noticias sobre la ilustre casa de la que descendería.

\section{Apreciaciones en torno al epistolario de Arias Montano, con motivo del hallazgo de la carta a Francisco de Aldana}

Los trabajos y proyectos de recuperación, catalogación, edición y estudio de la correspondencia de Arias Montano realizados en los últimos años han sido de notable envergadura, cuantiosos y totalmente decisivos para una comprensión cada vez más cabal de la figura del sabio frexnense y de su impronta en la cultura, la política y la religión europeas de su tiempo. ${ }^{15}$ Según la última actualización del inventario epistolar montaniano publicado en Early Modern Letters Online (EMLO), ${ }^{16}$ la correspondencia de Montano suma un total de seiscientas veintiuna cartas (doscientas setenta y cuatro enviadas y trescientas setenta y siete recibidas) que evidencian las amplísimas redes de contactos que el erudito extremeño, "con una destacable habilidad social, supo tejer allá por donde le llevaron sus peregrinaciones: Sevilla, primero, y después Alcalá, Amberes, Roma y Madrid”. Sin embargo, aun contando hoy con esa ingente cantidad de testimonios de la intensa actividad epistolar de Montano, sigue imponiéndose, como bien notó el profesor Antonio Dávila Pérez, "una fuerte impresión de que el trabajo de búsqueda no está agotado. De hecho, las más de quinientas cartas conservadas puede que sean tan sólo la punta del iceberg de la correspondencia de un polifacético humanista, curioso bibliófilo, experto en arte, influyente cortesano y eminente biblista". ${ }^{17} \mathrm{Y}$ así es, en efecto; pero conviene subrayar también la dificultad de la empresa y la

14. Para la estancia de Cosme en Milán, véase Cerrón Puga (1987-1988), Pintacuda (2009) y Montero Delgado, González Sánchez, Rueda Ramírez y Alonso Moral (2014: 345-365). Puede verse también el documento de concesión para el hermano de Francisco de Aldana de una merced de "veynte escudos de entreteni(en)to cada mes" en el Estado de Milán, en Archivo General de Simancas, Estado, leg. 1259, f. 205.

15. Cito solo las contribuciones más recientes y fundamentales en relación con el epistolario de Arias Montano: Macías Rosendo (1998, 2004 y 2008); Morocho Gayo (1998: 195-202); Dávila Pérez (2002a, 2002b, 2006, 2009, 2010, 2011, 2015a y 2015b); Morales Lara (2002 y 2004); Torrencio (2007); Lerner (2009); Arias Montano (Correspondencia).

16. Ver <http://emlo-portal.bodleian.ox.ac.uk/collections/?catalogue=benito-arias-montano>, catálogo digital, revisado y ampliado periódicamente por Antonio Dávila Pérez (Universidad de Cádiz). 17. Ambas citas en Dávila Pérez (2006: 67-68). En otro lugar, admite el mismo estudioso: "lo que ha quedado de la correspondencia privada del humanista espańol son solo las ruinas de lo que pudo llegar a ser" (Dávila Pérez 2015a: 128). 
escasa probabilidad de conservación del grueso de ese epistolario, ya que, por un lado, a diferencia de otros humanistas de su siglo, Arias Montano "no concedió nunca especial importancia a la difusión y publicación impresa de su correspondencia, al menos a la escrita en lengua castellana, ${ }^{18}$ como tampoco procuró quedarse con copias de las cartas que remitía. Por otro lado, hay que tener muy presente que la conservación de buena parte de las misivas enviadas por Montano ha obedecido, como pasa siempre, a la propia naturaleza, voluntad y relieve de los destinarios: gobernantes, hombres de Estado, insignes cortesanos, prelados, representantes de la élite intelectual europea, grandes personalidades, en definitiva, para quienes la carta, como transmisora de información privilegiada, era ya objeto de poder en sí mismo, un elemento material depositario de noticias, deseos, favores, reflexión o el más sentido afecto que podía ser utilizado de manera estratégica o personal en el amplio arco que va de los intereses públicos a los privados, de los obligados negotia de la corte al anhelado otium de la amistad y los saberes compartidos, y cuyo valor, ya fuera simbólico, político o cultural exigía su cuidada preservación. No es de extrañar, pues, que más de la mitad de las cartas conocidas de Montano discurran por los cauces habituales del patronazgo y del clientelismo, y que estén destinadas a nombres tan influyentes en sus respectivos campos de actividad como Felipe II, su secretario personal Mateo Vázquez, el secretario de Estado Gabriel de Zayas, el presidente de Indias Juan de Ovando, el Inquisidor General Gaspar de Quiroga, el Gran duque de Alba, su secretario Juan de Albornoz, el jurista y miembro del Consejo de Tumultos Juan de Vargas, el embajador en Roma Juan de Zúńiga, el arzobispo de Granada Pedro de Castro y Quiñones, el arzobispo de Milán San Carlos Borromeo, el cardenal Gugliemo Sirleto, el reputado humanista Fulvio Orsini, el geógrafo real Abraham Ortelio, el filólogo flamenco Justo Lipsio o el célebre naturalista Carolus Clusius. Las ocho cartas conocidas de Montano a Cristóbal Plantino y las once dirigidas a Juan Moreto merecen una consideración especial, pues se conservan en el Museo Plantin-Moretus de Amberes gracias al admirable mantenimiento del archivo familiar de la mítica imprenta antuerpiense. ${ }^{19}$ De igual modo, mención aparte requiere el único grupo de cartas de Montano que se ha conservado gracias a su propia intervención (exceptuando, naturalmente, las que él mismo insertó en diferentes obras impresas), esto es, las cartas enviadas en el marco de preparación y aceptación de la Biblia Regia a Andreas Masius, Johannes Sambucus, Gilbert d'Oignies, Cornelius Jansenius, Maximilien de Berghes, Viglius Zuichemus, Maximilien Morillon, Augustinus Hunnaaeus, Cornelius Reyneri o Wilhelmus Lindanus, reunidas por el propio escriturista en la colección documental del ms. A902 de la Biblioteca Real de Estocolmo. ${ }^{20}$

18. Domínguez Domínguez (2017: 9).

19. Dávila Pérez (2002a).

20. Macías Rosendo (1998). Por decisión de Montano, o acaso por el celo conservador de sus pupilos escurialenses, en el mismo manuscrito se puede hallar también una minuta autógrafa de 
Muy poco o nada queda de la correspondencia familiar que debió de mantener Arias Montano con parientes y con amigos de mucha menos alcurnia y autoridad que las de los distinguidos nombres mencionados arriba, pero también sobresalientes por sus letras y virtud, como es el caso del capitán Francisco de Aldana. La conservación del documento que enseño y que motiva las páginas de este estudio no solo resulta excepcional por el perfil discreto y peregrino del destinatario (si a la exigua posición social sumamos el trasiego de una vida aventurada, las posibilidades de que subsista algún rastro documental del individuo histórico siempre disminuyen), sino también por su condición de carta confidencial, escrita al paso y rápidamente, y encomendada (es decir, no remitida a través del correo ordinario) a las manos de un amigo común de extrema confianza. He aquí la carta, sin más dilación, que nos recuerda la amistad de aquellos dos seres extraordinarios: ${ }^{21}$

Ill[ustr]e s[eño]r mío:

Grandísima fue la soledad, tristeza y estrańeza q[ue] sentí qua[n]do, venido a esta corte, no hallé a v[uestra] $\mathrm{m}$ [erced], a quie[n] venía a buscar, para despacio co[m] municarle aq[ue]llo q[ue] más e[n]tie[n]do me podría dar co[n]tento e[n] esta vida. Allegóse a la ausentia de v[uestra] m[erced] el saber q[ue] estava aý occupado por muchos días, y pre[n]dado ya de provisiones y títulos para seguir cortes y servir a los reyes de la tierra y trattar en materias de guerra y otras cosas agenas de lo q[ue] algún día se co[n]fería. Todo lo e[n]derece N[uest]ro S[eño]r para su servi[ci]o.

Vine aquí de $S$ [ant] Lore[n] ço los postreros días de navidad co[n] lic[enci]a q[ue] Su Mag[esta]d me havía promettido para yr a ver mi choçuela e[n] la Peńa, y co[n] ocupaciones de corte y dilaciones de mi amo he perdido todo este mes, e[n] fin del qual me ha dado lic[enci]a co[n] encom[m]ienda q[ue] torne presto, de q[ue] doy a v[uestra] $\mathrm{m}$ [erced] aviso, y le supp[li]co pida a Dios e[n]derece mi camino para servi[ci]o suyo y me ma[n] de si e[n] alguna cosa le puedo dar gusto e[n] este viage o donde estuviere.

Aquel amigo y servidor de v[uestra] $\mathrm{m}$ [erced] $\mathrm{q}[\mathrm{ue}]$ los días pasados le co[m] municó sus buenos de<seos> tiene propósito de effettuarlos abrié[n]dole Dios puerta para ellos, y ha me dado ca<rgo $>$ de q[ue] dé esto a e[n]tender a v[uestra] $\mathrm{m}$ [erced] y le affirme $\mathrm{q}[\mathrm{ue}]$ en ninguna pers[on] a d'este $\mathrm{mu}[\mathrm{n}] \mathrm{do}$ tien $<\mathrm{e}$ con>fiança

una carta de 1588 que el frexnense envió a Levino Torrencio, segundo obispo de Amberes, y que no guarda ninguna relación con los trabajos de la Políglota; véase la carta en Charlo Brea (2004). Sí está vinculada a la polémica recepción de la Biblia Políglota de Amberes la única carta conocida de Montano al orientalista francés Gilbert Génébrard, cuya conservación en forma de borrador en el ms. 149 de la Biblioteca Nacional de España parece deberse igualmente a la voluntad y a los intereses de nuestro biblista; véase Dávila Pérez (2015b).

21. La transcripción de la carta es paleográfica literal con desarrollo de las abreviaturas. Solo se han modernizado, de acuerdo con las exigencias filológicas actuales, la puntuación, el uso de mayúsculas y la acentuación. Las aclaraciones del editor van en cursiva y entre corchetes; así, por ejemplo, [Firmado]. Los signos diacríticos utilizados en el texto son los siguientes: [ ] indica letras restauradas en el desarrollo de las abreviaturas; < > indica la adición de una letra omitida o de palabras suplidas por ilegibles en el original; ${ }^{* * *}$ indica laguna. 
q[ue] le sabrá procurar y adereçar su co[m] modidad sino es a v[uestra] m[erced], y $\mathrm{q}[\mathrm{ue}] \mathrm{co}[\mathrm{n}] \mathrm{g}<\mathrm{ran}>$ certeza parte muy assigurado a buscar aq[ue]l thesoro y co[n] cluir su casamiento $c o<$ n per $>$ sona $\mathrm{q}[\mathrm{ue}]$ tanto ama y deve amar, y rogóme q[ue] enco $[\mathrm{m}] \mathrm{me}<\mathrm{n}>$ dasse a $\mathrm{v}$ [uestra] $\mathrm{m}$ [erced] el secreto, por recelo de los adversarios y co[m]petidores, y ansí lo e[n] comie[n]do de su parte y de la mía. Ha me dexado una carta para v[uestra] $\mathrm{m}$ [erced], la qual yo no he querido fiar de los ca $<$ minos $>$ y tiempos, y queda aquí e[n]co[m]me[n]dada a un amigo fiel q[ue] sin saber cosa d'esto la ten<drá> guardada hasta q[ue] v[uestra] m[erced] venga y se la dará e[n] mano propria, remittié[n]dose e[n] la ex*** a lo q[ue] por tie[m]po succediere y al buen juicio e industria de v[uestra] $\mathrm{m}$ [erced], cuya ill[ustr]e pers[on] $<$ Nuestro Señor> en su servi[ci]o prospere. En Madrid, 30 de enero 1578.

$\mathrm{B}$ [esa] 1 [as] $\mathrm{m}$ [anos] de v[uestra] $\mathrm{m}$ [erced] su servidor ama[n]tísimo.

\section{[Firmado:] Arias Mo[n]tano}

[Post Scriptum:] Si la epístola e[n] verso no fuera para mí era digna de admiració $[n]$ de todos los buenos ingenios. Sea Dios be $[n]<$ dito por $>$ sus dones y maravillas.

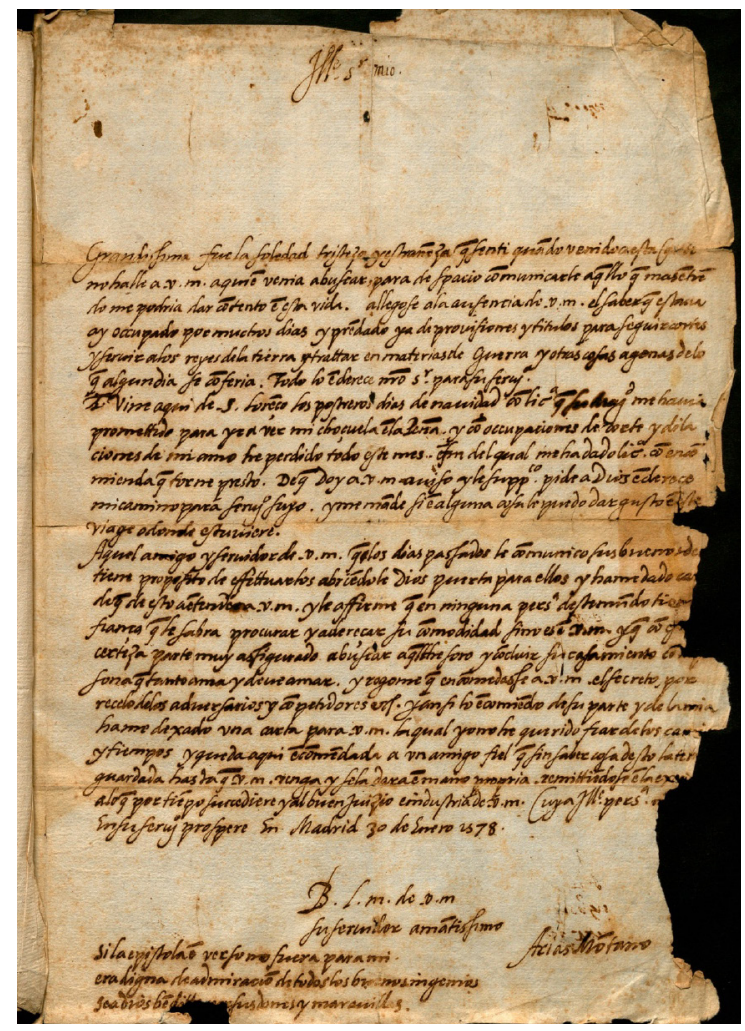

Carta de Benito Arias Montano a Francisco de Aldana, Madrid, 30 de enero de 1578 (Biblioteca del campus Barri Vell de la Universitat de Girona, Ms. Aldana, s. f.) 


\section{“Con quien hice común acá mi suerte". Aldana y Montano: dos vidas en correspondencia al servicio de la Monarquía Hispánica}

Antes de comentar y valorar el nuevo documento, quisiera exponer en forma de relato biográfico entrelazado hasta qué punto habían corrido en paralelo las experiencias, posturas, ilusiones, desencantos y anhelos respectivos de Aldana y Montano desde el inicio de sus relaciones en los Países Bajos. Aunque no se pueda demostrar documentalmente, es muy posible que el primer contacto entre ambos tuviera lugar a finales de mayo de 1568, cuando el escriturista, recién llegado a Flandes, se desplazó a Bruselas desde Amberes para presentarse ante el duque de Alba y entregarle la carta que para él llevaba de Felipe II. ${ }^{22}$ Por esas mismas fechas, Aldana se hallaba en la corte del Gobernador, al servicio particular de su persona, ${ }^{23}$ por lo que debió de ser testigo directo del buen recibimiento que dispensó Alba a aquel docto y benemérito criado del monarca, así como conocedor excepcional del negocio que llevaba en comisión, esto es, la supervisión de los trabajos filológicos de aquella magna obra enderezada "a gloria de Dios nuestro señor, aumento de su Santa Ley y beneficio de la Iglesia universal", ${ }^{24}$ la Biblia Políglota que Plantino imprimiría en Amberes..$^{25}$ Desde sus diferentes ámbitos de actuación, tanto el joven militar como el reputado teólogo iban a mostrar su adhesión total al Gobernador y a su política en defensa de la fe católica. Y por supuesto, ambos disfrutaron muy pronto de la estima del Gran Duque. De esta manera lo reconocía el poeta en su Respuesta a Cosme: "Aquí me estoy con mi señor y amigo / (puédolo así llamar, pues tal se muestra) / gozando de mirar cómo me mira / con ojos de verdad, de amor y gracia" ${ }^{26}$ Montano, por su parte, no podía menos que sentir el calor con que lo abrigaba el Duque, cuya admiración y respeto por el sabio lo inducían a buscar y a apreciar su exquisita conversación, y a tener en cuenta sus opiniones acerca del gobierno y de la política religiosa de los Países Bajos: "El duque huelga extremadamente con él, y tratan de mil materias excelentes". ${ }^{27}$ Bien conocida y más nítida es en este sentido la declaración que le hizo Montano a su amigo Juan de Ovando:

22. Puede verse la carta del rey al duque de Alba sobre el cometido encargado a Arias Montano en González Carvajal (1832: 144), doc. núm. 20.

23. Nievas Rojas (2020: 148-150 y 172-176).

24. Carta de Felipe II a Juan de Zúñiga, 19 de junio de 1572, en González Carvajal (1832: 164), doc. núm. 44.

25. "Luego me parti para Brusselas, donde fui bien recibido del duque d'Alua, que, por lo que ha entendido desta obra, no menos la ensalça que los que mas noticia della tienen", carta de Arias Montano a Felipe II, 6 de julio de 1568, en Arias Montano (Correspondencia, p. 77).

26. Respuesta a Cosme de Aldana, vv. 106-109, epístola con fecha de 10 de marzo de 1568, en Aldana (Poesías castellanas completas, p. 280).

27. Carta de Juan de Albornoz a Gabriel de Zayas, 29 de junio de 1569, en González Carvajal (1832: 132), doc. núm. 2. También citada en Rekers (1973: 25), Macías Rosendo (2008: 105) y Dávila Pérez (2011: 237). 
El duque d'Alva me haze mucha mer[erce]d, honor y favor en su casa y en toda esta tierra, porque me da el grado y lugar no que yo merezco, sino el que v[uestra] $s$ [eñoría] podría dessear que él me diesse, tanto que yo me hallo confuso. Entre otras cosas y mercedes me haze una que es algo a costa de mi tiempo, mas por entender que gusta d'ella la recibo yo por grande, y es que estando aquí me occupa quasi todas las tardes en que estemos parlando a solas; y quando estoy en Brusselas, las mañanas, y a la mesa, y después de mesa dos horas, y a la noche dos y tres y quatro. Tiene una discreción, memoria, juizio y distinctión de cosas que me tiene admirado, y juntamente una disposición en el trattarlas que parece estar exercitadíssimo en todas las materias. ${ }^{28}$

No es gratuito imaginar que la amistad entre Aldana y Montano tuvo su origen cerca y bajo el influjo imponente del duque de Alba. Su providencial misión de contener el avance del protestantismo y de apaciguar la revuelta flamenca encontró en Aldana y Montano a dos de sus más fervientes servidores, ${ }^{29}$ los cuales no tardarían en descubrir su primer vínculo afectivo en el reconocimiento y elogio sinceros de los logros del Gobernador en su lucha contra la sublevación y la herejía. Las octavas laudatorias que Aldana dirigió al duque de Alba tras su victoria sobre los rebeldes en Frisia y la estatua del Gran Duque ideada por Montano son pruebas incuestionables de esa admiración compartida. ${ }^{30}$ Además, tanto el poeta como el humanista contribuyeron activa y muy positivamente al éxito cosechado por la intervención de Alba hasta 1571, lo que les valdría la gran consideración que de ellos tuvieron siempre sus principales señores. Aldana, como ambicioso soldado y gentilhombre del rey "cerca la persona de sus generales", despuntó por su heroísmo en la batalla de Jemmingen y consiguió ganarse la plena confianza del Duque y del maestre de campo general Chiappino Vitelli, hasta el punto de que ambos dirigentes habían contado con

28. Carta de Arias Montano a Juan de Ovando, 6 de octubre de 1571. Cito por la edición de Macías Rosendo (2008: 238), pero puede verse también en Jiménez de la Espada (1891: 33) y Rekers (1973: 27). Para la íntima relación de Alba y Montano en Flandes desde un enfoque cultural, véase el trabajo de Gómez Canseco (2008).

29. Desde el mismo momento en que llegaron a los Países Bajos, Aldana y Montano manifestaron abiertamente su compromiso con los intereses de la Monarquía, mostrándose ansiosos por participar en la erradicación del problema flamenco. Para el caso de Aldana, que determinó, no se olvide, hallarse por propia iniciativa "en esta jornada q[ue] se ordena contra luteranos" (carta de Antonio de Aldana a Cosme I de Médici, 12 de marzo de 1567, citada en Nievas Rojas 2020: 154), contamos con la valiosa información de que el hispanoflorentino solicitó, cuando aún no llevaba ni tres meses en Flandes, unirse a la caballería de socorro que Alba envió al rey de Francia ante la amenaza hugonota (ibidem, 174-175); para el caso de Montano, disponemos de sus primeros textos dirigidos a la corte de Madrid, en los que se ofrece, "llevado por el entusiasmo del recién llegado al cargo y el afán de servir a su gran patrono", a "colaborar con todos los medios a su alcance en el análisis y solución de la rebelión de Flandes" (Dávila Pérez 2010: 15-17).

30. Véanse las octavas en Aldana (Poesias castellanas completas, pp. 291-295) y un correcto análisis de las mismas en García (2010: 385-391). Sobre Arias Montano y su papel en el proyecto de la controvertida estatua, véase Hänsel (1999: 68-84), Gómez Canseco (2008: 586-588) y Manegold (2013). 
su audacia para la embajada diplomática a la corte de Inglaterra de finales de 1569. ${ }^{31}$ De hecho, fue por esos años cuando el hispanoflorentino recibió su primera ventaja: una merced de veinte ducados al mes de entretenimiento. ${ }^{32}$ Durante ese mismo periodo, al margen de las tareas de dirección de la Políglota, Montano colaboró estrechamente con el duque de Alba en todo el aparato de censura y control ideológico de la Monarquía en los Países Bajos, lo que dio como resultado la publicación de los índices de libros prohibidos de 1569 y 1570, y del Index expurgatorius librorum qui hoc saeculo prodierunt, de $1571 .^{33}$ Añádase a esta actividad oficial de Montano su labor secreta como consejero y agente político del duque de Alba y de Felipe II. ${ }^{34}$ Como ha señalado Dávila Pérez, "la excelente reputación de teólogo y acreditado intelectual de la que Montano gozaba en la corte de Felipe II [...] sería motivo suficiente para que el rey hubiese planeado contar con Montano, desde el principio de su estancia en Flandes, para formar parte de la extensa red de informadores secretos que se extendía por todo el imperio". ${ }^{35}$ Así, pues, en vista de los indispensables servicios que el doctor Arias Montano era capaz de ofrecer a la Iglesia Católica y a la Monarquía, no ha de sorprender que el rey pidiera al duque de Alba "que os aprovechéis dél y le empleéis en cosas semejantes del servicio de Dios y mío, porque tengo por cierto que, según su buen zelo y entendimiento, las acertará cumplir a vuestro contento, y ansí os ruego tengáis cuenta con él para le honrar y favorecer en lo que se ofreciere". ${ }^{36}$

Parece evidente que la primera afinidad que sirvió como base de aquella incipiente amistad entre Aldana y Montano se conformó al arrimo de la sombra protectora del duque de Alba y en el convencimiento de que su gestión, militar y política, de la que ambos eran dignos partícipes, había allanado el camino a la pacificación de los Países Bajos. Obviamente, también el cultivo de la erudición y las letras debió atraer muy pronto los espíritus afines del poeta y el escriturista. Ocasiones, al menos, no faltaron para que poeta y biblista coincidieran en Amberes entre 1569 y 1571 (esto es, durante los años más tranquilos del conflicto),

31. Nievas Rojas (2020: 158-159 y 187-188).

32. "Francisco de Aldana dize q[ue] V[uestra] M[ajestad], ynformado de sus servicios por cartas del duque de Alva y particulares relationes del prior don Antonio y Chapín Vitelo, le hizo m[erce]d de veynte ducados de entretenim[ient]o en Flandes...”, memorial inédito y autógrafo de Francisco de Aldana dirigido a Felipe II, sin fecha, pero redactado con total seguridad en Madrid a finales de 1571; véase Archivo General de Simancas, Guerra y Marina, leg. 172, f. 174.

33. Sobre Arias Montano y su función en la censura de libros, ver Dávila Pérez (1998: 303-310) y Macías Rosendo (2008: 93-104).

34. La participación de Montano en el curso de los acontecimientos políticos de los Países Bajos es conocida desde el clásico estudio de Morales Oliver (1927), y ha sido bien atendida por Rekers (1973: 21-60) y Macías Rosendo (2008: 104-121). Las últimas aportaciones al tema, con importantes matices y novedades, se encuentran en Dávila Pérez (2010 y 2011).

35. Dávila Pérez (2010: 15).

36. Carta de Felipe II al duque de Alba, 22 de marzo de 1570, citada en Rekers (1973: 26). 
seguramente en alguno de los círculos intelectuales reunidos en torno a aquel centro de la cultura europea que representó la imprenta de Plantino. ${ }^{37}$

El 23 de mayo de 1571, Aldana recibió el permiso del duque de Alba para abandonar los Países Bajos y trasladarse a la corte española, lo cual haría llevando una magnífica carta de recomendación del Duque dirigida al Presidente del

37. Que Aldana y Montano empezaron a relacionarse en Amberes se da por sentado desde el estudio de Elias L. Rivers (1953: 537) y también por esta afirmación de Ángel Alcalá (1973: 249): "No se puede dudar de que ambos se conocieron en Amberes". Y lo mismo conjeturan, aun yendo un poco más lejos, Luis Gómez Canseco y Valentín Núñez Rivera (2001: 18-19), a raíz de una lectura crítica intertextual: "Cuando en 1568 Montano embarcó hacia Amberes para dirigir las tareas de impresión de la Biblia políglota, debía de llevar consigo copia de su Paráfrasis y, una vez allí, hubo de dársela a conocer a uno de sus nuevos y más devotos discípulos, el poeta Francisco de Aldana”. Todo apunta a que fue así, en efecto, pero el contacto solo pudo producirse a partir de 1569 , terminada ya la primera campaña contra las fuerzas orangistas. A propósito de las páginas de Alcalá (1973: 250), cabe decir que su propuesta de que "no es imposible que Aldana cayera en Flandes bajo incipiente iniciación familista" por medio de Montano carece completamente de indicios documentales y de análisis histórico (véase también Alcalá 1998: 99). Es más: ni siquiera la supuesta adscripción de Montano a la secta holandesa de la Familia charitatis está libre de sospecha, como ya puso de manifiesto Morocho (1998: 205-207) y como ha insistido en varias ocasiones Dávila Pérez (2011: 258), extendiéndola a Plantino: "We need not propose adherence to any sect whatsoever in order to explain the irenic ideology that brought Montano to maintain contacts with Catholics and Protestants, or the preference he expressed for an internal religiosity over the formalism of ceremonies: these ideas simply show the heritage of the Erasmian philosophia Christi that he, and other Spanish humanists, learned at Seville and Alcalá. As for Plantin, attention should be drawn to the strong evidence presented by Paul Valkema Blouw that the printer's first contacts with the sect had a mainly commercial aim”. Véase también Dávila Pérez (2003: 304-306). Más sugestiva y prometedora en términos de estudio resulta la documentada pertenencia de Aldana a la Accademia dei Confusi de Amberes (Ramos 2018), integrada en su mayoría por mercaderes genoveses y fundada por Stefano Ambrosio Schiappalaria, cuya traducción del cuarto libro de la Eneide (1568) salió de las prensas de la Officina Plantiniana. Estos datos permiten esbozar algunas de las redes de relaciones intelectuales, comerciales e incluso clientelares que conectaron a Aldana y Montano en la escena antuerpiense, por las que también corren nombres de servidores mediceos, como el del comerciante y escritor florentino Lodovico Guicciardini (cuyo epitafio para su sepulcro en la catedral de Amberes compuso, entre otros, Justo Lipsio [Battistini 1949: 46], conocido amigo de Montano, y a quien Schiappalaria dedicó un soneto para los preliminares de su Descrittione di tutti i Paesi Bassi, de 1567, reeditada por Plantino en 1581 y 1583) o el del condottiero tifernate Chiappino Vitelli, amigo y protector de Aldana y uno de los máximos responsables por aquellos días de la construcción de la ciudadela de Amberes. La mención a estos dos criados de los Médici, próximos al poeta hispanoflorentino, no es baladí, teniendo en cuenta que Montano intercedió alguna vez en favor de sus intereses ante la corte española. Por ejemplo, en carta de Montano a Zayas firmada en Amberes a 11 de febrero de 1569, se lee: "El marques Chapin Vitello y el Guicciardino besan las manos de v. m. y tienen grande sperança de que por su mano se ha de proueer la abbadia [de las Dunas] a aquel buen hombre de quien ellos y todos dizen tanto bien" (Arias Montano, Correspondencia, p. 173). La relación de Arias Montano y Lodovico Guicciardini debió ser estrecha, a juzgar por una carta de Daniel Barbaro a Montano, del 16 de abril de 1569, por la que sabemos que este confió al florentino unas muestras de la Políglota para que se las hiciese llegar al humanista veneciano (Arias Montano, Correspondencia, p. 219). Las relaciones de Chiappino Vitelli con Montano y Plantino tuvieron que ser igualmente cercanas, como se infiere del aviso del impresor al biblista de la muerte de Vitelli a principios de noviembre de 1575 (Dávila Pérez 2002a: 277). Para las figuras de Vitelli y Guicciardini y sus vínculos con los circuitos intelectuales y artísticos de Amberes véase Mavilla (2016 y 2018). 
Consejo de Castilla, don Diego de Espinosa. En dicha carta, Alba suplicaba al omnipotente cardenal tan encarecidamente como podía que tuviese a Aldana "por muy encomendado, y en lo que se le ofreçiere hazerle toda la $\mathrm{m}[\mathrm{e}] \mathrm{r}[\mathrm{ce}] \mathrm{d}$ y favor que hubiere lugar y la que merece[n] sus servicios [...], que toda la que V[uestra] S[eñoría] I[llustríssima] le hiziere la estimaré yo y terné en el mismo lugar que si fuesse por mí propio" ${ }^{38}$ Gracias a esta intercesión, y a las particulares relaciones que de Aldana debió de hacer Chiappino Vitelli en sus audiencias con Espinosa y Felipe II en julio y agosto de $1571,{ }^{39}$ el poeta obtuvo antes del 24 de enero de 1572 una conducta de capitán, sin duda el mayor reconocimiento de su carrera hasta la fecha. ${ }^{40}$ En el mes de marzo, Aldana ya habría levantado casi trescientos infantes en las ciudades de Alcalá de Henares y Guadalajara. Antes de junio, estaría embarcado con su compañía en Cartagena para ir "donde se hallare el Señor don Juan de Austria" y combatir al Turco. ${ }^{41}$

Por su parte, Arias Montano continuaría aún en los Países Bajos por espacio de un año, ultimando los trabajos preparatorios para la impresión de la Políglota. A decir verdad, la salida de Montano de los estados flamencos no se contemplaba en España de ninguna manera. Sus valiosos advertimientos del 5 de febrero de 1571 a la corte de Madrid acerca de las cosas públicas de Flandes y su carta a Zayas del 28 de agosto sobre la errada política fiscal de Alba coadyuvaron a que Felipe II viera en la persona de Montano una inestimable fuente de información y de asesoramiento político. ${ }^{42}$ De ahí que, hacia finales de 1571, concluido ya el grueso del proyecto de la Biblia Regia y, por tanto, también el cometido oficial y principal de Montano en los Países Bajos, Felipe II se dirigiera a su capellán real para comunicarle su deseo de que permaneciera en Flandes sirviendo y aconsejando al duque de Medinaceli, el malogrado y fallido sucesor del duque de Alba:

38. British Library, Western Manuscripts, Add. Ms. 28385, f. 202 (carta citada en Rivers 1953: 507). 39. Véanse las cartas que Vitelli envió desde Madrid a Francisco I de Médici y al secretario Bartolomeo Concini, del 11 de agosto de 1571, en Archivio di Stato di Firenze, Mediceo del Principato, 650, ff. 339-340 y 357, así como las cartas que los embajadores toscanos enviaron a Florencia ese mismo verano, en Ibidem, 4903, s. f.

40. Véase el memorial inédito y desconocido citado en la nota 32, en el que, al ofrecerse "ocasión de nombrarse capitanes para que hagan jente", Aldana "suplica a V[uestra] M[ajestad] sea servido q[ue] él ocupe una plaça de los deste número, porque tras veynte años de servicio piensa tenlla merecida, como ofreciéndose lo mostrará en obras", en Archivo General de Simancas, Guerra y Marina, leg. 172, f. 174. Además, véase la carta, también inédita y desconocida, que Aldana dirigió a Francisco I de Médici el 24 de enero de 1572 desde Alcalá de Henares para informar al príncipe de Florencia sobre la obtención de la capitanía, en Archivio di Stato di Firenze, Mediceo del Principato, 570, f. 183r.

41. Véanse las órdenes, inéditas, de Felipe II a Francisco de Aldana (5 de febrero) y a Pedro de Chaide (17 de marzo), en Archivo General Militar de Madrid, Libros de Registro, lib. 3, f. 67r-v y lib. 4, f. 201r, respectivamente.

42. Véanse los dos informes en la Colección de documentos inéditos para la historia de España (en adelante CODOIN), tomo XLI (1862: 200-235 y 253-254). 
Y porque, según esto, tengo por cierto que vuestra assistencia y advertimientos serán muy útiles al Duque de Medinaceli, que va a residir en essos estados por mi Governador y Capitán General, he acordado que os detengáys y quedéys en ellos por algunos días. Os encargo y mando que lo hagáis assí, y todo lo que de mi parte y por mi serviçio os dixere y pidiere el Duque, como de Vos se confía, avisándole (además d'esto) de las cosas que os paresciere deve ser advertido, a fin que las d'essa provincia se pongan en el estado que conviene al serviçio de Dios y mío. ${ }^{43}$

Sin embargo, el 4 de febrero de 1572, el embajador en Roma Juan de Zúñiga se vería obligado a redactar una carta para Felipe II que marcaría la suerte y el destino inmediato del sabio frexnense. Ante las objeciones que el Papa había presentado a la concesión de la aprobación y el privilegio de la Políglota, Zúñiga instó al rey para que, "si el Doctor Arias Montano ha acabado lo que tiene que hacer en Flandes [...], le mandase venir aquí con la misma Biblia, y satisfaciendo él a estas cosas que ahora oponen a esta obra, y mostrando algunas partes della, y con la relación que él haría de todo, podría ser que [...] se entendiese de cuánto fruto será que salga a luz y que S. S. la aprobase". ${ }^{44}$ Así, el 23 de abril de 1572, por mandado de Felipe II, Montano dejaba los Países Bajos y ponía rumbo hacia la Ciudad Eterna ${ }^{45}$ No defraudó su comisión en Roma, pues tan solo cuatro meses más tarde, exactamente el 23 de agosto, otorgaba el nuevo pontífice (Gregorio XIII, por defunción de Pío V) su aprobación a la Políglota, refrendada el 1 de septiembre por un motu proprio, aunque ya el día antes había escrito Juan de Zúniga a Felipe II acerca del éxito de Montano en los siguientes términos: "en cuanto a este negocio Arias Montano queda despachado, y S. S. le ha honrado y favorecido como merecen sus letras y virtud; las cuales se han estimado en esta Corte tanto como en todas las otras partes donde él ha dado muestras dellas y tiene muy merecido toda la merced que V. M. le hace". ${ }^{46}$

Una de las razones que se aducen para explicar el triunfo del frexnense ante la curia romana, aparte de las que estriban en sus habilidades diplomáticas, se asienta en la idea de que Gregorio XIII quiso iniciar una política de acercamiento a la Monarquía Hispánica, sobre todo después de la victoria que la armada española acababa de obtener contra los turcos en Lepanto. ${ }^{47}$ De hecho, justo por aquellos

43. Carta de Felipe II a Arias Montano, 9 de noviembre de 1571; cito por la edición de Macías Rosendo (1998: 262-263).

44. Carta de Juan de Zúńiga a Felipe II, 4 de febrero de 1572, en González Carvajal (1832: 160), doc. núm. 37.

45. Y lo hacía patrocinado, como Aldana el año anterior, por una carta credencial del duque de Alba, remitida esta al Sumo Pontífice a 20 de abril de 1572, en la que le suplicaba, "como quan encaresçidamente puedo, me haga a mí merced de mandalle hazer, en lo que se le offreçiere, la que huviere lugar, favoreçiéndole tan de veras quanto lo meresçe persona que tanto serviçio ha hecho a esa Sancta Sede", en Macías Rosendo (1998: 280).

46. Carta de Juan de Zúñiga a Felipe II, 31 de agosto de 1572, en González Carvajal (1832: 165), doc. núm. 47.

47. Rekers (1973: 77). 
días en que se negociaban en Roma los asuntos relativos a la Biblia Regia, en las aguas de Levante tenía lugar el desarrollo de la segunda campaña de la Santa Liga contra las fuerzas otomanas, expedición mucho más perseguida por los intereses vitales de Venecia y de los Estados Pontificios que por los del Rey Católico. ${ }^{48}$ Las noticias que llegarían de esta jornada, repleta de dificultades políticas y materiales, contratiempos, órdenes, contraordenes, retrasos y, sobre todo, confusión, debieron preocupar en el Vaticano y condicionar de algún modo la posición del Papa con respecto a sus relaciones con España. ${ }^{49}$ Dar el visto bueno a la Políglota significaba, pues, fortalecer la alianza entre la Santa Sede y la Corona española, cuya expresión máxima se estaba efectuando y poniendo a prueba, en aras de la Cristiandad toda, en la gran guerra del Mediterráneo Oriental.

Allí, precisamente, al tiempo que Montano defendía su obra en Roma y lograba granjearse la confianza del Sumo Pontífice, Aldana alcanzaba el rango más alto que ostentaría en vida, el de sargento mayor de los mil españoles que don Juan de Austria, ante la determinación de las fuerzas papales de salir al encuentro de la flota turca, concedió al almirante de las galeras romanas Marco Antonio Colonna para que pudiera adelantarse, el 7 de julio, primero a Otranto, y de ahí a Corfú y a Citera, mientras la mayor parte de la flota cristiana permanecía en Messina junto a don Juan, a la espera del beneplácito de Felipe II. ${ }^{50}$ No obstante, apenas tuvo Aldana la oportunidad de aprovechar su nuevo y elevado cargo. Si la campaña de 1571 había concluido con la gran victoria de Lepanto, esta vez los resultados fueron, como mínimo, decepcionantes: las expediciones de Morea no implicaron más que un par de encuentros sin estragos entre las flotas rivales a principios de agosto, alrededor de Citera, un asedio absolutamente infructuoso al puerto de Navarino por parte de la escuadra de don Juan a mediados de septiembre y un desembarco no menos frustrante de la infantería española en las costas de esa misma isla a principios de octubre. La armada turca, refugiada en Modón, se había limitado a fortificar la plaza y a esperar a que el mal tiempo y los problemas logísticos de los coaligados obligaran a don Juan a abandonar la empresa. El 8 octubre, un día después del primer aniversario de Lepanto, la flota cristiana se replegaba sobre Zante y, desconcertada, emprendía el camino de regreso a Messina. ${ }^{51}$ Ese mismo 8 de octubre, curiosamente, Montano abandonaba Roma y

48. Braudel (2018: 619-625) y Rivero Rodríguez (1996: 603-609).

49. El 25 de julio llegó a Roma la noticia sobre la orden definitiva de Felipe II de proseguir con la campaña de Levante. Como explica Luciano Serrano (1918: 282), "tan visible satisfacción produjo esta noticia en la Corte romana, que pareció la de una gran victoria y fue considerada como presagio del buen éxito de la Liga".

50. El mando de Aldana en esta campaña se refiere en los testimonios del historiador florentino Giovanni Battista Adriani (1583: 913), del cronista espańol Antonio de Herrera (1601: 507) y del erudito napolitano Biagio Aldimari (1691a: 194). Y Aldana mismo lo consigna en su memorial a Felipe II de septiembre de 1577.

51. Serrano (1918: 143). 
emprendía su viaje de vuelta a los Países Bajos. Llegaría a Venecia el 22 de octubre y a Milán a primeros de noviembre, receloso de un invierno "que se me entraba a mas andar" ${ }^{2}$ y que le haría presagiar la dureza del trayecto y, posiblemente, también, la violencia desatada que hallaría en su destino. ${ }^{53}$

No iban a ser muy diferentes la experiencia y el itinerario de Aldana. El invierno que se anticipó y sobrevino a finales de 1572 determinó la singladura de una infantería destinada a combatir en el Mediterráneo y que acabaría, para su sorpresa, alojada en el Estado de Milán, y, finalmente, siendo ordenada a servir contra su voluntad en los Países Bajos. El 28 de octubre, por mandato de don Juan, el almirante Juan Andrea Doria zarpó de Messina con dirección a Génova, llevando en sus galeras trece compañías del Tercio de don Lope de Figueroa que debían invernar en Lombardía. Una de ellas, indudablemente, era la de Aldana. ${ }^{54}$ La travesía resultó complicadísima, aunque peor suerte correrían las galeras y los hombres en ellas embarcados. Varias tormentas obligaron a las embarcaciones a refugiarse primero en Gaeta y después en la Isla de Elba, llegando finalmente a Génova, a la deshilada, a partir del 28 de noviembre. ${ }^{55}$ La Señoría prohibió desembarcar a la tropa, e incluso que la flotilla anclase dentro del mandrache, por lo que debieron quedar al muelle de la dársena exterior. La noche del 30 de noviembre "se levantó una tormenta de las mayores que he visto, la qual duró hasta ayer de mañana", sufriendo mucho las galeras, tripulaciones y soldados, ya que "se ahogava la gente dentro de las propias galeras". Doria hubo de meter las galeras en la dársena interior para repararlas y desembarcar a la gente, que encaminó al Estado de Milán, viéndose en la tesitura de tener que desobedecer las nuevas órdenes del rey, que por medio de Luis de Requesens, gobernador de aquel Estado, y de Sancho de Padilla, su embajador en Génova, le ordenaban llevarla por mar a Civitavecchia o Porto Ercole. Doria justificó la desobediencia no solo por la imposibilidad de navegar con sus galeras, sino porque el mal estado de la tropa, "de puro escarmentada y maltratada de la tormenta, demás de estar desnuda”, desacon-

52. Carta de Arias Montano a Felipe II, 18 de diciembre de 1572, en CODOIN, tomo XLI (1862: 279).

53. Sobre las dificultades del viaje de regreso a Flandes y el impacto del invierno en la salud del biblista: "Io sono arrivato a questi paesi Bassi salvo e libero de li pericoli del viaggio, la Dio merce, ma con un puoco d'indispositione a causa de la invernata crudissima e de la varia intemperie de regioni donde ho passato", carta de Montano a San Carlos Borromeo, 24 de enero de 1573, en Tellechea Idígoras (1998: 71).

54. El dato se revela en dos cartas desconocidas de Aldana a Cosme I de Médici y a Francisco I de Médici, del 23 de marzo de 1573, en Archivio di Stato di Firenze, Mediceo del Principato, 586, ff. 356r y 413r.

55. Aldana no llegó a Génova hasta finales de diciembre o principios de enero, pues cuando las galeras de Doria fueron a parar a la Isla de Elba debido al temporal, el poeta pidió licencia para recalar en algún puerto de Toscana e ir a Pisa y a Florencia, ciudades en las que se detuvo algunos días para besar las manos de Cosme I de Médici y las de su hijo el príncipe Francisco; véanse las carta citadas en la nota anterior. 
sejaba que pudiera proseguir después su viaje, dirigiéndose hacia el Reino de Nápoles o al de Sicilia, tal y como había ordenado el rey en su último despacho. ${ }^{56}$ En consecuencia, esas trece compañías del Tercio de don Lope quedarían repartidas en los alojamientos del Milanesado por el resto del invierno, y, pese a las muchas quejas y demandas de don Juan de Austria, y pese a no perder estos soldados hasta el último momento "la esperança de volver a la Armada", ya no se incorporarían a la nueva campaña contra el Turco, puesto que serían enviadas a Flandes por orden de Felipe II ante el recrudecimiento de la segunda rebelión de los Países Bajos y la insistencia de refuerzos por parte del duque de Alba. ${ }^{57}$

He considerado pertinente y necesario dar cuenta, aun incurriendo en excurso, de estos azarosos acontecimientos porque solo su explicación permite comprender que en modo alguno era esperable que Aldana regresara a territorio flamenco, como tampoco lo era, bien mirado, que lo hiciese Arias Montano. En una carta escrita la víspera de su viaje a Roma, el frexnense ya se lamentaba de que "mis peregrinaciones no se acaban aún ni entiendo qué suerte sea la mía, que tan al revés se me ordena de lo que desseo, que es recogerme en la Peña o en otro lugar más escondido"..$^{58}$ Por esta razón, cuesta muy poco suponer el escaso entusiasmo con que Montano debió de recibir la orden de Felipe II por la que partió de nuevo a Flandes una vez finalizada "tan honradamente" su extenuante misión en Roma. Juan de Zúñiga se lo comunicaba al rey con estas palabras, en una carta escrita a los pocos días de la partida del sabio:

Afflígese mucho de que V. M. le mande ocupar en negocios que son fuera de su profesión y paréscele que si $\mathrm{V}$. M. fuese servido de darle licencia para que se recogiese que podría hacer mucho servicio a la Iglesia y a V. M. en escribir, y los que

56. Todos estos pormenores provienen de la minuciosa carta que Juan Andrea Doria envió a Felipe II, a 5 de diciembre de 1572, en Archivo General de Simancas, Estado, leg. 1402, f. 116. Puede verse también una aproximación a estos mismos hechos en Pacini (2013: 299-304).

57. La última cita textual proviene de una crítica, un tanto injusta, que Requesens hizo llegar a Felipe II acerca de la actitud de los soldados del Tercio de don Lope, que, según el Gobernador, "vinieron persuadidos que los embiavan a Lombardía a gozar de las delicias del mundo (como ellos dizen) y a comer a discreción [...]. Y ha me dicho el de Figueroa que una de las cosas que amotina la gente demás de las que he dicho es haver en cada compañía destas ocho o diez soldados de los que han estado en Flandes [...]; y estos predican mil males de Flandes y que no ternán jamás libertad de salir. Y crea V[uesra] M[ajesta]d que han andado y andan de manera que he tenido harto temor que se desvergonçasen a amotinarse [...]. Y convendría que V[uestra] M[ajesta]d embiase a mandar al $S[$ eñ] or Don Juan que qualquiera destos que llegasen a la Armada no solo no se recojan, pero que se hechen al remo y aun se haorque alguno, pues no es justo que siendo vassallos de V[uestra] M[ajesta] $\mathrm{d}$ y tan bien pagados no vayan a servir donde se les manda", carta de Requesens al rey, 15 de abril de 1573, en Archivo General de Simancas, Estado, leg. 1236, f. 77. Para el alojamiento del Tercio de don Lope en Lombardía y la resolución de enviarlo, contra el parecer de don Juan, a los Países Bajos, véase, en el legajo citado, los ff. 5, 10 y 24; y también Biblioteca Nacional de España, Ms. 783, ff. 283r-285v, 291r-292r y 306r-309v; y CODOIN, tomo CII (1892: 56-59 y 61).

58. Carta de Arias Montano a Juan de Ovando, 2 de abril de 1572; cito por la edición de Macías Rosendo (2008: 269). 
han visto sus obras y entienden de cuánto provecho son, le cargan la conciencia de que prosiga en la escriptura. ${ }^{59}$

Aunque Felipe II respondiera a esta carta asegurando que "lo que me advertís cerca de mandar desocupar a Montano para que gaste el tiempo en escribir [...] me ha parecido de consideración, y assí lo terné en mirar en ello", ${ }^{60}$ y por muy grandes que fueran las "speranças que me dan de que v[uestra] m[erced] será por acá presto", ${ }^{61}$ como escribió desde Espańa Juan de Ovando a su amigo Montano, ${ }^{62}$ este haría su entrada en los Países Bajos el primero de diciembre de 1572 para, apenas tres meses más tarde, recibir la siguiente orden de Felipe II: "por el servicio que con vuestro buen celo y doctrina podéis hacer a Nuestro Señor y a su Iglesia en esos Estados, he acordado que por agora os quedéis y residáis en ellos". ${ }^{63}$ Ciertamente, esta resolución no debió desconcertar a Montano, pues ya para entonces había podido comprobar el estado lamentable en que se hallaban las cosas de Flandes, "que están miserabilísimas", ${ }^{64}$ y deducir fácilmente que su presencia allí sería requerida por más tiempo. "Es una grande ruina la que aquí he hallado y me rompe el coraçón ver tanta mudança”, le había escrito el frexnense a Juan de Ovando en enero, consciente de que sus afanes de retiro no iban a cumplirse por el momento: "no me hallo affecionado a otra parte que a la Peña, aunque no sé quándo se me cumplirá este desseo, y voy trabajando por hazer lo que v[uestra] s[eñorí]a en una suya me aconsejó, que hiziesse la Peña en mi pecho". ${ }^{65}$

59. Carta de Juan de Zúñiga a Felipe II, 13 de octubre de 1572, en González Carvajal (1832: 166), doc. núm. 48; también citada en Dávila Pérez (2011: 248). A Montano se le encargó la supervisión de libros litúrgicos y de los privilegios para la conclusión de la Biblia Políglota, "entre tanto que se me da nueva materia de servicio" (Montano al rey, 18 de diciembre de 1572, CO$D O I N$, tomo XLI [1862: 280]), que no sería otra que la de informar a la corte espańola de los problemas de Flandes y asesorar al próximo gobernador de los Países Bajos, Luis de Requesens.

60. Carta de Felipe II a Juan de Zúñiga, 14 de noviembre de 1572, en González Carvajal (1832: 167), doc. núm. 51.

61. Carta de Juan de Ovando a Arias Montano, 23 de noviembre de 1572, en Macías Rosendo (2008: 274).

62. En carta a Montano de 8 de abril de 1572, Ovando accede a interceder en favor del biblista para solicitar su regreso a Espańa; y, según parece, lo hace por petición del propio Montano: "Yo tengo salud y cada día me hallo mejor en esta tierra, aunque fuera con mucho más contentamiento si tuviera a v[uestra] $\mathrm{m}$ [erced] en ella. Y así lo solicitaré, por hazer lo que v[uestra] $\mathrm{m}$ [erced] manda y por el ynterés que me va en ello”, en Macías Rosendo (2008: 264).

63. Carta de Felipe II a Arias Montano, 24 de febrero de 1573, en González Carvajal (1832: 167), doc. núm. 52.

64. Carta de Arias Montano a Gabriel de Zayas, 15 de febrero de 1573, en CODOIN, tomo XLI (1862: 284).

65. Carta de Arias Montano a Juan de Ovando, 20 de enero de 1573, en Macías Rosendo (2008: 278). Es necesario señalar, como brillantemente ha expuesto Dávila Pérez, que, a partir de este momento, Montano va a "iniciar una ofensiva desde diversos frentes para tratar de obtener el licenciamiento de sus obligaciones como capellán real", con el fin de "retirarse de la vida pública para dedi- 
La situación en Flandes era, en efecto, desastrosa. En el momento de la llegada de Arias Montano, ciudades como Malinas, Mechelen, Zutphen o Naarden, que se habían declarado a favor del príncipe de Orange, acababan de ser víctimas de la política de brutalidad e inclemencia del duque de Alba. Convencido "de que sus adversarios eran infrahumanos, quizá inspirados por el diablo", y de que su insubordinación representaba el permiso de Dios para castigarlos de manera ejemplar, el Gran Duque resolvió guiarse por las leyes de la guerra "como cuestión de orgullo de clase y como expresión de su lealtad al orden superior por el cual combatía" ${ }^{66}$ Toda ciudad rebelde que ofreciera resistencia o un simple pretexto para hacer caer sobre ella el veredicto de un Dios justo merecía, pues, ser aniquilada, sin que quedase "ánima nascida que no se pase por el cuchillo". ${ }^{67}$ Los asesinatos masivos y los pillajes sistemáticos perpetrados por un ejército mal pagado que consideraba legítimo su botín definieron una estrategia basada en el terror que empañaría aún más la reputación del duque de Alba y que no solo "haría pedazos la tenue esperanza aún viva de reconciliación entre el rey y sus súbditos", ${ }^{68}$ sino que también desbarataría el poco apoyo con el que todavía contaba el Duque en las cortes de Bruselas y Madrid para insistir en su intransigencia y en sus despiadados métodos. Así las cosas, aun a sabiendas (o precisamente por ello) de que su crueldad era el centro de todas las miradas, Alba, desde su cuartel general de Nijmegen y por medio de su hijo Fadrique, dirigió a principios de diciembre su personal expedición punitiva y disuasoria hacia las puertas de Haarlem. El 12 de diciembre, apenas dos semanas después del regreso de Montano, se puso cerco a una ciudad cuya decidida, prolongada y heroica oposición iba a costar miles de vidas a uno y a otro bando, a socavar y a la vez enfurecer los ánimos de los españoles y, sobre todo, a herir mortalmente

carse a lo que consideraba su misión, el comentario de la Biblia para el servicio de la Iglesia Católica" (Dávila Pérez 2015a: 122 y 135). Así es: justo al día siguiente de escribir a Ovando, Montano redactó una carta para el erudito Juan Rethio en la que manifestaba su aflicción por no poderse dedicar al estudio de las Sagradas Escrituras debido a "los negocios ajenos que nos vimos obligados a acometer y gestionar por mandato de nuestro rey completamente en contra de mi voluntad e incluso con mi resistencia”. Por ello, Montano solicitó al destacado jesuita que reuniese y le enviara el mayor número posible de cartas "escritas a mí por señores sabios y consagrados a la utilidad de la pública religión [...]. Pues pienso enviar al rey y a los ministros reales [...] una copia de las cartas que tengo de este argumento llegadas desde Italia, Francia, Espańa junto con las alemanas, y considero que esta idea va a tener entre ellos [...] muchísima fuerza para que todos al unísono desistan de ese interés de ocuparme en asuntos públicos y ajenos a mi proyecto con la idea y expectativa de una tarea mejor y más útil; y me concedan el descanso del que ahora tanto necesito para recuperar la propia salud", carta latina de Arias Montano a Juan Rethio, 21 de enero de 1573; sigo la traducción al español de Dávila Pérez (2015a: 149 y 151). Nótese cómo el biblista intenta sacar rédito de esta hábil maniobra en su carta a Zayas del 27 de febrero (CODOIN, tomo XLI, 1862: 288).

66. Maltby (2007: 378-379).

67. Carta del duque de Alba a Felipe II, 31 de agosto de 1573, en Alba (Epistolario del III Duque de Alba, p. 502).

68. Maltby (2007: 377). 
el régimen del duque de Alba. Haarlem no se rendiría hasta pasados siete meses desde el inicio del sitio, es decir, el 12 de julio de 1573, solo cuando la llegada de las tropas de socorro procedentes de Milán a finales de junio hizo realmente inútiles los esfuerzos de los defensores de la villa. ${ }^{69}$ Contra toda predicción, al frente de una de esas compañías que llegaron de Italia en tan penosa coyuntura estaba el capitán Aldana. ${ }^{70}$ No tardaría en comprobar el hispanoflorentino, como su amigo Montano, la desgraciada deriva de la rebelión flamenca.

En esta ocasión, pese a ordenar la ejecución a sangre fría de 2.300 soldados (entre franceses, valones, ingleses y alemanes bajos) que habían servido a Orange tras los muros de Haarlem, el duque de Alba usó del castigo, según sus propias palabras, "con misericordia", ${ }^{71}$ pues dispuso excusar el saqueo de la ciudad a cambio de que sus habitantes pagaran una indemnización de 240.000 florines. Seguidamente, Alba publicó unas admoniciones y un perdón dirigidos a las villas rebeldes de Flandes, con el fin de reducirlas a la obediencia por "el camino de la blandura". ${ }^{72}$ Aunque no se haya comentado en ningún estudio, es prácticamente seguro que la tajante y más que controvertible clemencia del Gran Duque (considerada, como no podía ser de otra manera, atrocidad por los holandeses) resultara de la influencia de Arias Montano, cuyo punto de vista sobre la rebelión y los procedimientos de Alba para sofocarla había cambiado respecto a su opinión inicial ante el conflicto, virando hacia posiciones absolutamente conciliadoras. Salvo en lo tocante a la "libertad de conciencias, que es un mote que de poco acá ha inventado el Diablo y mettido en los pueblos por boca de los rebolvedores dellos", Montano se mostraba partidario de transigir con las tierras rebeladas y de someterlas por la vía de la bondad siempre que fuera posible, como había escrito en marzo en una carta para Juan de Albornoz enviada al campamento militar del duque de Alba, en Nijmegen:

Todavía tengo por bueno siempre encommendarlos a Dios y procurar de vencerlos por bien y amontonar con esto carbones sobre sus cabeças. Y quando fuese neces-

69. Sobre la urgencia y esperanza "que de esa gente tengo", como escribía Alba a don Lope de Acuña el 15 de junio refiriéndose a los refuerzos que venían de Italia (Alba, Epistolario del III Duque de Alba, pp. 438-439), puede verse la opinión de Chiappino Vitelli, para quien, gracias a "l'arrivo" de "le genti che vengano d'Italia [...], si può credere che presto si darà fine a questa guerra", carta de Vitelli a Francesco I de Médici, 5 de junio de 1573, en Archivio di Stato di Firenze, Mediceo del Principato, 651, f. 195r.

70. Véase la relación inédita del "número de los soldados de los tercios de Lombardía y don Lope de Figueroa que van a Flandes”, en la que el nombre de Francisco de Aldana figura al mando de una compañía de ciento ochenta y tres soldados perteneciente al Tercio de don Lope (el cual pasó a llamarse inmediatamente Tercio de la Liga, y luego Tercio de Santiago), en Archivo General de Simancas, Estado, leg. 1236, f. 98.

71. Carta del duque de Alba a Felipe II, 28 de julio de 1573, en Alba (Epistolario del III Duque de Alba, p. 472).

72. Carta del duque de Alba a Felipe II, 31 de agosto de 1573, en Alba (Epistolario del III Duque de Alba, p. 502). 
sario usar de la fuerça, usarla valientemente a fin siempre de reduzirlos a su bien del qual huyen. Y ansí espero en Dios que los perdones y gracias que se hazen a los vezinos serán de frutto para este propósito. ${ }^{73}$

Luego, en el mes de abril, el frexnense se desplazó hasta Nijmegen para visitar al duque de Alba, donde debió de transmitirle las mismas ideas que vertería semanas más tarde en un discurso que envió a Gabriel de Zayas sobre la necesidad de adoptar medidas benignas y de acercamiento:

[...] Es necesario administrarse estas guerras de manera que se excusen semejantes inconvenientes y peligros [...], y hacer cuenta que el príncipe es en tal caso un padre de familia que halla a sus familiares todos, o todos los más, enfermos de locura, que su studio es apretarlos, y encarcelarlos y castigarlos, a fin de que se curen y sanen, y con tal intento y orden y no a fin de matarlos [...]. Con el ejemplo de la misericordia usada en los rendidos y de la liberalidad y honra acerca de los fieles y constantes, los buenos tomarán alientos y cobrarán ánimo para perseverar, y muchos de los otros se rendirán, confesando haber sido engańados y seducidos como aun al presente muchos lo dicen y publican, y desta manera tengo por cierto se recobrarán muchos corazones perdidos y otros obedecerán por temor y respeto, y poco a poco se irán recobrando. Yo afirmo que se ganará diez doblado más por esta vía que por fuerza o miedo [...]; bien habemos visto lo que se ha ganado con el ejemplo de Narden y Zutfen que para mí tengo este haber sido el clavo que ha fijo los corazones de Harlen y de Holanda, que primero estaban malos, empero dudosos.

[...] A mi poco entender yo ternía por acertado consejo en continente, que un pueblo fuese o ganado por fuerza o vuelto y rendido de su voluntad, publicarles un perdón en cuanto toca a la rebelión, diciendo que se les admite la excusa de haber sido inducidos con malos reportes y con engaños y mentiras, y apercibiéndoles que de ahí adelante vivan en la religión y obediencia de su rey, el cual siendo ellos tales les será padre.

[...] En ninguna manera me parece se debe proceder sin clemencia, junta aun con la fuerza de la guerra cuando esto fuese necesario. ${ }^{74}$

Sin llegar a renunciar nunca a su espíritu de cruzada, es indudable que el duque de Alba, "después de muy bien mirado y platicado con las personas que aquí se hallan conmigo" ${ }^{75}$ tuvo en cuenta los consejos de Montano cuando redactó la circular que haría divulgar el 16 de julio por las ciudades sublevadas:

73. Ambas citas provienen de la carta de Arias Montano a Juan de Albornoz, 28 de marzo de 1573, en Archivo de los duques de Alba, C.28/181. Sigo la transcripción que me ha facilitado muy generosamente el profesor Antonio Dávila Pérez, a quien agradezco su precioso gesto. Por lo que atañe a "los perdones y gracias que se hazen a los vezinos", Montano debe de referirse a las ciudades que, tras el saco de Zutphen, enviaron su declaración de lealtad y suplicaron que se les perdonaran sus pasadas culpas, como Kampen, Zwolle, Hasselt, Steenwijk, Harderwijk o Amersfoort (Mendoza 1592: 172r).

74. Informe de Arias Montano, probablemente dirigido a Gabriel de Zayas, entre el 11 de abril y el 17 de junio de 1573, en CODOIN, tomo XXXVII (1860: 89-90 y 92).

75. Carta del duque de Alba a Felipe II, 28 de julio de 1573, en Alba (Epistolario del III Duque de Alba, p. 472). 
¡No dubdamos, en alguna manera, que estaréis bien informados de las admoniciones y persuasiones que estos días pasados os han sido hechas de la parte de S. M., la cual, conforme a la costumbre de sus predecesores, vuestros príncipes y soberanos señores, y como un buen padre que admite y recibe su hijo por muy perdido que esté cuando viene a conoscimiento, ha procurado reduciros so la obediencia que le es debida, de la cual os habéis enajenado y caído en rebelión, dándoos seguridad que la ofensa que en esto podríades haber cometido [...] sería puesta en olvido y perdonada por S. M., la cual [...] es a saber: de la clemencia que cada uno sabe es tanto más inclinado a ella por conoscer que vuestra falta ha procedido más por inducimiento de malignos que de vuestro proprio y natural motivo, no se pudiendo en manera alguna persuadir que hayáis tanto decaído de vuestro ser que si no fuera por esto hubiéredes continuado en la fidelidad, lealtad y promptitud que vosotros y todos vuestros antecesores habéis siempre mostrado [...]. Todavía S. M., sin tener respecto a esto ni buscar ni pretender otra cosa sino tornaros a juntar y [...] poneros debajo de sus alas, protección y salvaguardia, nos ha encargado, por otra vez y la última, que os amonestemos que, teniendo más respecto a vuestro deber que por lo pasado y al bien y salud de todos vosotros, os vengáis a reconoscer y voluntaria y prontamente a poner en sus manos [...]. Mas si vosotros os descuidáis y pasáis estas amonestaciones a la sorda y con obstinación, como hasta agora, nos os queremos juntamente prevenir que no hay rigor, por áspero que sea, que no debáis esperar. ${ }^{76}$

De nada sirvió que voces como la de Montano imbuyesen su voluntad reconciliadora en la exigencia escrita del duque de Alba. Tras las represalias contra Haarlem, ninguna ciudad se rindió ya a los españoles sin previa resistencia. ${ }^{77}$ Alkmaar, Enkhuizen y el resto del norte holandés permanecieron leales a la causa orangista, la cual se hallaba entonces tanto o más operativa que en 1567 . La de Alba, en cambio, con su particular odio hacia herejes y traidores, estaba perdida. Bien lo sabía Montano desde hacía varios meses, siendo, como era, "testigo de miserias que no puedo en parte alguna remediar si no llorarlas y encomendarlas a Dios, que es el que solo puede remediarlas y convertirlas del camino de perdición a la qual van muy a furia tiradas" ${ }^{78}$ Pero, aunque Montano discrepara de la línea de severidad trazada por el Duque, jamás le retiraría su amistad ni su apoyo. Llevado siempre tanto por el verdadero aprecio que le tenía como por la indispensable deferencia del sometimiento cortesano, el sabio frexnense humanizó y defendió la figura de Alba incluso en los momentos en que la reputación del Duque se vio más minada y su gobierno cada vez más al borde del precipicio. En febrero, escribía Montano a Zayas: "El duque d’Alba está más afligido que v. m., ni persona otra alguna podrá creer, y no es posible menos

76. Carta del duque de Alba a las villas rebeldes de Flandes, 16 de julio de 1573, en Alba (Epistolario del III Duque de Alba, pp. 462-463).

77. Parker (1989: 158).

78. Carta de Arias Montano a Juan de Zúñiga, 30 de mayo de 1573, en The Morgan Library \& Museum, RS, p. 1522, núm. 455. Sigo la transcripción que me ha facilitado con gran amabilidad Antonio Dávila Pérez, a quien quedo nuevamente agradecido. 
añadiéndose tantos cuidados y trabajos a tanta edad y enfermedad". ${ }^{79} \mathrm{Y}$ a finales de mayo, con Haarlem humeante y sin rendirse aún, le comunicaba a Zúñiga:

El Duque haze lo que puede, y es más que persona alguna podría jamás creer de su edad y soledad si no lo viesse, porque con tanta falta de salud estoy maravilladíssimo cómo puede durar en la imaginación, provisión y assistencia de tantas cosas tan pesadas e importantes. Verdad es que él de noche y de día otra cosa no haze ni entiende sino trattar de lo que conviene al remedio destos estados, sin respetto de su salud ni de otra incommodidad propria, y encomendarse a Dios reconociendo venirle de su mano qualquiera buen successo. ${ }^{80}$

Ni siquiera la noticia de la sustitución de Alba por Luis de Requesens en el gobierno de los Países Bajos suscitó en Montano la más mínima revisión de sus juicios sobre el Duque. ${ }^{81}$ Es más: en cuanto se le informó de la nueva y de la firme posibilidad de la vuelta de Alba a España, Montano no vaciló en declararse fiel servidor de su persona, llegando, además, a manifestar abiertamente su deseo de acompañarlo: "Si el Duq[ue] huviere de estar mucho tiempo en estos estados serme ha muy fácil de llevar qualquiera carga con su favor y calor. Si, como V[uestra] M[erced] significa, se huviere de yr a Espańa, quedaré con esperança que luego me sacará de aquí para que le sirva allá”. ${ }^{82}$ Claro está que a esta

79. Carta de Arias Montano a Gabriel de Zayas, 15 de febrero de 1573, en CODOIN, tomo XLI (1862: 284-285).

80. Carta de Arias Montano a Juan de Zúñiga, 30 de mayo de 1573, en The Morgan Library \& Museum, RS, p. 1522, núm. 455.

81. Aunque en sus informes de 1573 Montano manifieste su oposición a la política de Alba, siempre encontrará el modo de excusar al Gran Duque. Así se aprecia, por ejemplo, en unos advertimientos inéditos y desconocidos redactados por Montano (probablemente el 5 de septiembre de 1573, en respuesta a la petición de Zayas del 17 de julio sobre el "verdadero remedio que se podría poner" a las cosas de Flandes [CODOIN, tomo XLI, 1862: 292]). Escribe el frexnense: "Y nunca fuero[n] oýdos los $\mathrm{q}[\mathrm{ue}]$ llevavan las informaciones y remostraciones desto en particular y en general, no $\mathrm{p}$ [or] falta del gobernador principal, sino $\mathrm{p}$ [or] q[ue] avía grandes recados y obstáculos pa[ra] q[ue] estas cosas no viniesen a sus oýdos, y no se remediando, el mal cresçía”, en Bibliothèque Publique et Universitaire de Genève, Collection Edouard Favre, vol. LX, ff. 274r-278r (cita en ff. 274v-275r). Esta aclaración en descarga del duque de Alba Montano la reiterará en sus apuntamientos de finales noviembre: "ay muchas cosas que por no avérsele declarado con verdad a él mismo, y con la senzillesa devida, y no averlas él sabido sino por relaciones aviesas le son muy persuadidas, y conforme a tal persuasión an sido tratadas", copia de relación de Arias Montano enviada al rey, 29 de noviembre de 1573, en Macías Rosendo (2008: 293). Incluso cuando lleguen a Bruselas los rumores de la caída en desgracia de los Toledo tras su regreso a España, Montano emitirá sin titubeos una defensa acérrima del duque de Alba y de su hijo Fadrique: "Acá se han derramado en estos días algunas cosas contra la estimación del duque d'Alba y de su hijo, y del licenciado Vargas y de los demás sus ministros, las cuales he tenido y tengo por falsas, y ansí las contradigo abiertamente. Han venido de allá las simientes dello, y no lo puedo creer, porque entiendo el duque llevó de aquí su conciencia saneada, y sé que hizo cuanto pudo por curar esta república, la cual se enfureció como frenética, aborreciendo al médico, y no dejándose curar dél", carta de Arias Montano a Gabriel de Zayas, 18 de abril de 1574, en CODOIN, tomo XLI (1862: 306).

82. Carta de Arias Montano a Juan de Albornoz, 28 de marzo de 1573, en Archivo de los duques de Alba, C.28/181. 
demostración de sumisión, tan habilidosa y modélica desde la óptica de las relaciones clientelares, subyacía el ansia por la consecución de un único anhelo: el retiro en la Peńa de Aracena. "En lo que toca a mi particular afirmo a v. m. delante de Dios que yo soy muy ajeno de ambición, de dignidades ni otros estados, y que el mayor que siempre he deseado ha sido hasta agora tornarme a mi Peña" ${ }^{83}$ Así se lo había expresado Montano a Zayas en el mes de febrero; en mayo, le expuso lo mismo al influyente embajador de Felipe II en Roma, pero esa vez, el imparable deterioro de la realidad flamenca empujaba al biblista a transmitirlo en forma de lamentación y ruego:

No podrá V[uestra] S[eńorí]a Ill[ustríssim] a ymaginar la miserable faz de las cosas acá. A mí me pone tanta lástima y cuydado que no he tenido día entero de salud después que a mi casa torné. Todo el mes passado de abril estuve con trabajo de una fiebre continua de la qual aún estoy en convalescencia. Y ansí he hecho muy poco de cosa que sea de provecho en mis studios ni ministerios. Harto más creo huviera empleado bien el tiempo si desde Roma fuera a parar a la Peña.

[...] Haviendo yo acabado lo que al presente hago con el favor de Dios y estando libre de deudas, V[uestra] S[eñorí]a Ill[ustríssim] a me ha de favorecer en pedir a Su Mag[es]t[ad] una merced, para mí grandíssima y espero será util para n[uest]ros próximos, y de ninguna costa para Su Mag[es]t[ad], que es lic[enci]a para me recoger en alguna soledad y gastar allí el resto de la vida en lo que toca a la salvación mía y de otros. ${ }^{84}$

Viendo sacudida la región de Flandes "por una rebeldía criminal / y feas enfermedades y un vicio interno, / y precipitada, a través de incontables desastres, / a su perdición", el frexnense no podía sino añorar los días de "felicidad en la gruta / de la recóndita y eminente Peña”, como reconocería el propio Montano en la oda dedicatoria a Pedro Vélez de Guevera compuesta por esos meses. ${ }^{85}$ Aunque el humanista gozara como nunca de la confianza de Felipe II, y aun del amparo y estima del duque de Alba, un profundo sentimiento de desilusión se instaló en el ánimo de Montano a causa de tanta corrupción de la vida pública y del "interior de los pechos mortales". ${ }^{86}$ Todo, absolutamente todo lo encontraba el biblista invadido por "la antorcha encendida de la violencia" y por "las

83. Carta de Arias Montano a Gabriel de Zayas, 27 de febrero de 1573, en CODOIN, tomo XLI (1862: 287).

84. Carta de Arias Montano a Juan de Zúñiga, 30 de mayo de 1573, en The Morgan Library \& Museum, RS, p. 1522, núm. 455.

85. La composición, que contiene numerosas revelaciones autobiográficas, aparece al final del volumen en el que Montano versionó en metros líricos latinos los ciento cincuenta salmos del Salterio, titulado Dauidis regis ac prophetae aliorumque sacrorum uatum Psalmi, ex hebraica ueritate in Latinum carmen a Benedicto Aria Montano obseruantissime conuersi ("Antverpiae, Ex officina Christophori Plantini, Architypographi Regij, M. D. LXXIII”). Los versos citados (88-91 y 3233, respectivamente) provienen de la traducción espańola de Pozuelo Calero (2011).

86. De Benito Arias Montano a don Pedro Vélez de Guevara, v. 109, en Pozuelo Calero (2011). 
agresiones", y por "una codicia vergonzante y hambrienta / que no conoce límites" ${ }^{87}$ De ahí que, a finales de junio, Montano insistiera, de nuevo en carta a Zúñiga, en que la tierra estaba "miserablísima, destruyda de los enemigos y de los que son por nosotros", y que implorase, con amarga resignación, "que Dios lo remedie y me saque de tan triste spettáculo". 88

A mediados de 1573 Flandes era, en efecto, un triste espectáculo, en el que también hubo de actuar, muy a su pesar, el capitán Aldana. Por más que el poeta creyera, como el duque de Alba, en la teoría de que la causa de la revuelta era de carácter puramente religioso ${ }^{89}$ y que, por tanto, participara del "argumento agustiniano que determina la guerra contra los herejes como guerra de Dios"90 (es decir, justa y, sobre todo, santa), Aldana comprendió pronto el correlato terrenal y humillante de esa sacralización del conflicto: la fatiga y la frustración desencadenadas por la duración de la guerra y por la creciente sospecha de su inutilidad. El primer signo de pesadumbre que descubrió Aldana cuando regresó a los Países Bajos fue, sin duda, la inexorable decadencia del mandato de Alba reflejada en el descontento de sus tropas. Como es sabido, la victoria pírrica del ejército realista sobre Haarlem se vio empañada por la alteración de los veteranos españoles, quienes se amotinaron el 29 de julio en reclamo de sus más de veinte mensualidades atrasadas. Aunque Alba consiguió resolver el motín el 16 de agosto por mediación del maestre de campo general Chiappino Vitelli, ${ }^{91}$ el desorden anunciaba un fenómeno terrible en el que Aldana también debería mediar más adelante y que, a la postre, comportaría el desastre financiero y militar sobre la Monarquía Hispánica. Con todo, el hispanoflorentino todavía pudo sentir cierta satisfacción personal, pese a las malas condiciones del campo, cuando, al marchar por fin el ejército hacia el Norte, vio de algún modo reforzado su codiciado prestigio con su designación como teniente de la artillería, lo cual le confirmaba que seguía manteniendo el favor del duque de Alba, de su hijo Fadrique y, por supuesto, de Vitelli. ${ }^{92}$

87. Ibidem, vv. 101-104, en Pozuelo Calero (2011).

88. Carta de Arias Montano a Juan de Zúñiga, 28 de junio de 1573, en The Morgan Library \& Museum, RS, p. 1522, núm. 454. Sigo la transcripción de Antonio Dávila Pérez.

89. Aldana mantuvo esta creencia prácticamente hasta el final de su vida: "Ya, contra tus decretos, se defiende / la flamenca región, que tanto cuesta; / ya de hereje furor toda se enciende, / alza de rebelión la fiera cresta, / muéstrase toda armada la campaña / que la Schelda y la Mosa riega y baña", Octavas dirigidas al rey don Felipe, nuestro señor, vv. 395-400, en Aldana (Poesías castellanas completas, p. 411).

90. Lara Garrido (1985: 82).

91. Véase la crónica de Mendoza (1592: 212r y 215r) y la carta de Vitelli a Francesco I de Médici, del 16 de agosto de 1573, en Archivio di Stato di Firenze, Mediceo del Principato, 651, ff. 227r-229v.

92. Cabe matizar que su elección como teniente de la artillería, aunque denotara un gesto de confianza por parte de sus principales autoridades, no significó para Aldana un ascenso en sentido estricto, como creía Rivers (1953: 511). Explico por qué. En la segunda jornada de Levante Aldana sí ascendió, aunque solo temporalmente, al cargo de sargento mayor, pero una vez finalizada la campaña quedó de nuevo al mando de una compañía de infantería, ostentando el rango de capi- 
No obstante, el destino flamenco ya no proporcionaría a Aldana ningún aliciente para engrandecer su carrera, y sí, desde luego, abundantes desgracias. La primera de ellas, de hecho, le aconteció a finales de aquel mismo verano (o sea, a las puertas del invierno en Holanda) ante los muros de la ciudad de Alkmaar. Allí, siendo "el tiempo el más terrible que se ha visto jamás, que en todo el mes pasado y parte de este no ha hecho otra cosa que llover, de manera que ya en todo el campo no se podía andar sino el agua hasta la rodilla, entretanto los soldados a hacer la guardia descalzos y el artillería casi anegada, llegando el agua por cima de las piezas", ${ }^{93}$ Aldana fue herido de un mosquetazo en un pie, probablemente durante el ataque precipitado, descoordinado y, consecuentemente, fallido, que ordenó Fadrique el 18 de septiembre en su desesperado intento por tomar la villa y por restituir in extremis la dignidad de su casa. Pero el daño recibido en el fatal asalto, del que "habían quedado estropeados -en palabras de Alba- casi todos los oficiales", ${ }^{94}$ y el miedo a que la rotura de los diques a manos de los orangistas, junto con los

tán. Este es el grado, obtenido en España en enero de 1572 (véase la nota 40), que poseía Aldana cuando fue nombrado, a petición de Vitelli, teniente de la artillería (véase la carta de Requesens al marqués de Cetona, del 14 de julio de 1574, en la que se dice explícitamente que "por su orden sirve el capitán Aldana el dicho cargo", en Nueva colección de documentos inéditos para la historia de España y de su Indias —en adelante Nueva CODOIN_, tomo III [1893: 379]). Como explico en mi tesis doctoral, aún en curso, Rivers (1957: XX) se equivocó al afirmar que "Aldana sirvió como general de la artillería en los sitios de Haarlem y de Alkmaar". El crítico norteamericano se basó en las referencias del título del Diálogo entre cabeza y pie (Aldana, Poesías castellanas completas, pp. 385-388) que traen las ediciones del Divino preparadas por Cosme de Aldana, donde se indica que el poeta fue herido "sobre Arlen" (dato erróneo, por duda y desconocimiento del hermano, en los impresos de 1589 y 1593) y "sobre Alquemar" (rectificación acertada, al averiguar Cosme más tarde el lugar exacto donde Francisco recibió el mosquetazo, en el impreso de c. 1595) "sirviendo el oficio del General de la Artillería". Debido al escaso conocimiento que se tiene de la terminología historio-bélica del momento, se ha creído que servir "el oficio del General de la Artillería" solo podía significar poseer tal cargo o graduación, cuando en realidad también quería decir fungirlo o desempeñarlo accidentalmente, por orden jerárquica superior y siempre que faltara su titular por ausencia, enfermedad o cualquier otra causa. En modo alguno pudo Aldana desempeñar el generalato de la artillería, salvo en alguna acción muy concreta y con escaso número de piezas y artilleros, puesto que él era capitán de infantería. La infantería y la artillería no eran armas compatibles ni interdependientes, sino completamente separadas y distintas, sin ningún nexo ni posibilidad de interpromoción. Está claro que, en su habitual e irrefrenable tentación de sobredimensionar los lauros familiares, a Cosme se le fue la mano al llamar la atención sobre la experiencia artillera de su hermano, no solo en las ediciones mencionadas, sino también en la Segunda parte de las obras que dedicó a la memoria de Francisco: "en Alq[ue]mar después, tierra más fuerte, / exerçitando nuevamente un grado / mayor, herido fue casi que a muerte / el héroe immortal, fiero y osado (Cosme de Aldana 1587: 18). (Nótese que, en 1587, dos años antes de que publicase por primera vez las poesías de su hermano, Cosme no albergaba duda respecto al lugar donde había sido herido Francisco.) En cualquier caso, mucho más comedido fue el capitán Aldana cuando redactó su memorial de 1577, donde solo aludió al mando de "batterías q[ue] allá se ofrecieron" (Archivo General de Simancas, Guerra y Marina, leg. 82, f. 156; transcrito en Rivers 1957: LII-LIII).

93. Carta del duque de Alba a Felipe II, 23 de octubre de 1573, en Alba (Epistolario del III Duque de Alba, p. 538); citada también en Rivers (1953: 511-512).

94. Ibidem., en Alba (Epistolario del III Duque de Alba, p. 538). 
continuos vientos y las mareas altas, inundaran la región circundante y, con ella, las posiciones españolas, pusieron en evidencia que Alkmaar iba a ser la primera ciudad rebelde en resistir a un ejército realista. Y efectivamente: entre el 8 y el 10 de octubre, Fadrique, tan derrotado y moralmente abatido como su padre, ordenó levantar el asedio, o lo que es lo mismo: la última cruz que hubo de cargar Alba en los Países Bajos. Así, el 18 de diciembre, un mes después de la llegada a Flandes de Luis de Requesens como nuevo gobernador y capitán general, el duque de Alba, consciente de que "yo ya aquí no soy otra ninguna cosa que estorbo", 95 abandonaba Bruselas e iniciaba el largo camino de regreso a la corte madrileńa.

Atrás dejó el duque de Alba a Montano y a Aldana. El poeta, obligado a guardar cama y convalecencia por la herida sufrida en Alkmaar, difícilmente hubiera podido viajar con el Duque; en cambio, Montano sí podría haberlo hecho perfectamente, como a buen seguro debió solicitárselo a Alba el propio humanista cuando supo de su inminente partida. Por una carta de Zayas al Duque, en la que el secretario preguntaba de parte de Felipe II por las causas por las que "le parece no debe quedar ahí Arias Montano", ${ }^{96}$ se deduce que Alba había intercedido en favor del frexnense para que este obtuviera su deseado licenciamiento de sus obligaciones oficiales. Ante la demanda de una mayor concreción respecto al asunto de Montano, Alba siguió mediando por él, y replicó francamente:

A la quedada aquí de Arias Montano diré que la causa que me movió a escrebir que no convenía fue parecerme que si a un buen zapatero le mandan hacer una pintura la borrará toda y no sabrá por dónde la ha de comenzar. Él es bonísimo hombre y es cargo grande de conciencia quitarle de sus estudios y ocuparle en otras cosas donde no puede hacer el beneficio que hace con ellos a la cristiandad. ${ }^{97}$

La intercesión de Alba no podía dar de ningún modo los frutos esperados. Los informes políticos que Montano había enviado a la corte española la pasada primavera y, sobre todo, los advertimientos acerca del remedio de los males de Flandes remitidos en septiembre ${ }^{98}$ habían convencido a Felipe II de la necesi-

95. Carta del duque de Alba a Felipe II, 22 de octubre de 1573, en Alba (Epistolario del III Duque de Alba, p. 531).

96. Carta de Gabriel de Zayas al duque de Alba, 21 de octubre de 1573, en Archivo General de Simancas, Estado, leg. 554, f. 4 (citada en Rekers 1973: 40).

97. Carta del duque de Alba a Gabriel de Zayas, 3 de diciembre de 1573, en Alba (Epistolario del III Duque de Alba, pp. 563-564); véase también Rekers (1973: 40).

98. Como se ha indicado en la nota 81 , se trata de un documento inédito y desconocido, unos "Advertimientos del doctor Arias Montano sobre el remedio de las cosas de Flandes", que vienen a satisfacer la siguiente petición de Zayas a raíz de la recepción de los dos informes (uno de materia política y otro sobre cuestiones religiosas) que Montano había enviado a Madrid entre el 11 de abril y el 17 de junio: "Con las susodichas cartas de v. m. han venido dos discursos harto buenos del miserable estado de esa provincia, y así lo he referido a $S$. M. d; pero lo que quiere y en lo que v. m. le servirá mucho es en que de los mismos de la tierra entienda v. m. como de suyo cuál es el verdadero remedio que se podría poner [...], y que juntamente con los medios digan cómo se podrán poner en 
dad de que su capellán real permaneciera cerca del sustituto de Alba en el gobierno de los Países Bajos, Luis de Requesens, asesorándolo en su difícil misión de reconstruir la paz y de ganar la voluntad de los naturales por medio de políticas más tolerantes y conciliadoras que las de su predecesor, como la implantación de un régimen de perdón o la aplicación de medidas efectivas como la abolición del diezmo o del tan abominado Consejo de Tumultos. Era en vano, pues, que Alba se esforzara en exponer la causa por la que convenía liberar a Montano de sus tareas públicas. La decisión de Felipe II, desgraciadamente para el frexnense, ya estaba tomada. Dos meses antes de que Alba respondiera a $\mathrm{Za}-$ yas, el rey se había dirigido al nuevo gobernador para expresarle su deseo de que se dejase orientar por la experiencia de Montano:

Ya sabéis cómo ha días que reside en Anvers el Doctor Arias Montano [...], ocupado en la impresión de la Biblia quadrilingüe y otras cosas al servicio de Dios y mío, en que ha procedido muy acertadamente. Envióme este día una relación de particularidades que allí ha entendido, que paresciéndome que es bien que vos las sepáis he mandado que se os envíe con esta copia della. Y si os paresciere conferir y platicar con él las cosas que en ella se apuntan, lo podréis hacer [...], favoresciendo y honrando a Montano cuanto sabéis que lo merece por su virtud y buenas partes. ${ }^{99}$

El 21 de octubre, el mismo día que Zayas preguntaba al Duque por las razones por las que "no debe quedar ahí Arias Montano", Felipe II, juzgando hombre de estado a su capellán, hacía despachar su orden definitiva al propio biblista:

Recibí vuestra carta de 5 de septiembre y la relación que con ella venía [...]. Y porque las particularidades que contiene la dicha relación son de calidad; que habiendo de ser agora mi Gobernador y Capitán general desos Estados el Comendador mayor de Castilla [Requesens], era necesario que las supiese, le mandé enviar una copia [...] para que si fuese menester las pudiese platicar con vos, y así os encargo que hagáis en esta parte lo que él os pidiere, advirtiéndole de lo que más viéredes convenir al beneficio desa provincia, en la cual es mi voluntad os quedéis a residir por agora, que desto seré servido, y el Comendador mayor terná con vos la cuenta que merescéis. ${ }^{100}$

ejecución [...]; y S. M. ${ }^{\mathrm{d}}$ desea el remedio como verdadero padre, y así lo ha de dar v. m. a entender en todas las partes y comunicaciones que se ofrecieren", carta de Gabriel de Zayas a Arias Montano, 17 de julio de 1573, en CODOIN, tomo XLI (1862: 292-293). Este nuevo -y decisivo- informe debe de ser el del 5 de septiembre que refiere Felipe II en carta a Montano (González Carvajal 1832: 168, doc. núm. 52). El documento que se conserva en la Bibliothèque Publique et Universitaire de Genève, Collection Edouard Favre, vol. LX, ff. 274r-278r es, casi con total seguridad, la copia que el rey mandó enviar a Luis de Requesens del susodicho informe.

99. Carta de Felipe II a Luis de Requesens, 4 de diciembre de 1573, en González Carvajal (1832: 168), doc. núm. 52. 2.

100. Carta de Felipe II a Arias Montano, 21 de octubre de 1573, en González Carvajal (1832: 168), doc. núm. 52.3. 
Montano hubo de asumir disciplinadamente y con lealtad no solo un papel de agente y consejero político encubierto cada vez más activo, sino también todo tipo de tediosas actividades relacionadas con la publicación o el comercio de libros, desde la supervisión de las obras del nuevo rezado hasta la evaluación, corrección o censura de textos extranjeros, pasando por la adquisición de libros para el Escorial y por los numerosos encargos que, en este sentido, le hacían cortesanos españoles. ${ }^{101}$ Pero, por mucho que contara con la confianza del gobernador y del rey, o que fuese generalmente amado tanto por su ejemplar y piadosa vida como por su gran erudición, ${ }^{102}$ Montano no dejó de considerar absurda e innecesaria la prolongación de su estancia en Flandes, como se lo comunicó a su amigo Zayas el 14 de abril de aquel año fatídico que iba a ser 1574:

En cuanto al servicio que yo acá hago, como no tengo particular oficio ni administración, ni título ni otra cosa en que me emplee más de decir mi parecer cuando se me pregunta, y algunas veces yo de mío dar algunos avisos y entretener este cuidado que aquí se debe tener de la buena corrección de todos los libros, y que no se admitan libros malos de fuera, en esto yo hago lo que puedo en lo uno y en lo otro, y lo que alcanzo, con toda llaneza, limpieza y sin pasión, en lo cual confío se sirve Dios; empero fuera desto ni tengo cargo de que haya de dar cuenta, ni lo que en esto hago nace, como digo, de obligación o vocación ordinaria, sino acaso.

El comendador mayor me hace mucha honra y merced, y me comunica cuando estamos en un lugar algunas cosas, en las cuales digo lo que siento y entiendo desapasionadamente, $\mathrm{y}$ allende desto le doy noticia de algunas personas eclesiásticas y seglares, idóneas a mi parecer para servir; empero todo esto es danzar sin concierto ni concertado. ${ }^{103}$

Aunque Montano lograra sobrevivir con éxito al cambio de gobierno de los Países Bajos gracias a su extraordinaria habilidad social y política para reconocer y obtener el favor de aquellos grandes patronos cuya influencia podía satisfacer sus pretensiones, ${ }^{104}$ la gran desesperanza que el frexnense venía padeciendo desde finales de 1572 se tornó, ante la crudeza de los acontecimientos de 1573 y el presagio de los que aún estaban por llegar en 1574, en una crisis personal sin precedentes,

101. Véase a este respecto el documentado estudio de Bécares Botas (1999).

102. Es muy revelador el testimonio de Thomas Wilson, embajador de la reina Isabel I en Flandes, acerca de la imagen de hombre culto, bueno, poderoso y desprovisto de malicia de que gozaba Arias Montano en los Países Bajos; véase la carta del Dr. Wilson del 13 de marzo de 1574 dirigida a Lord Burghley, en Calendars of State Papers Foreign: Elizabeth, XI, núm. 46 (1880), en línea: <http://www.british-history.ac.uk/cal-state-papers/foreign/vol11/pp19-40> (se cita en Morales Oliver 1927: 296-297).

103. Carta de Arias Montano a Gabriel de Zayas, 14 de abril de 1574, en CODOIN, tomo XLI (1862: 303-304).

104. Dávila Pérez (2011: 261). Desde su juventud, Arias Montano mostró una enorme pericia a la hora de fraguar amistades estratégicas. Como afirma Guy Lazure (2006: 111) en un artículo breve pero lúcido, el frexnense "aprendió en Sevilla las reglas inherentes al complejo sistema de mecenazgo y clientelismo que movían las relaciones sociales de la época”. 
agudizada, además, por una salud delicadísima. Tan solo el ejercicio poético, científico y escriturario, desarrollado en el exiguo "tiempo que aquí puedo ahorrar o libertar de las enfermedades y ocupaciones", ${ }^{105}$ conseguiría rehacer el espíritu del sabio "cuando estoy a punto de venirme abajo, / al sacarme del fastidioso trabajo / de mi molesto oficio". ${ }^{106}$ En efecto, obras como los Divinarum nuptiarum conventa et acta (colección impresa a mediados de 1573 por el antuerpiense Anthonis Coppens van Diest y reeditada, con algunas modificaciones, en las mismas prensas en 1574), la traducción en verso de los Salmos, titulada Dauidis regis ac prophetae aliorumque sacrorum uatum Psalmi, ex hebraica ueritate in Latinum carmen (poemario que, junto con varias composiciones prologales y una oda alcaica a Pedro Vélez de Guevera, fue dado a la imprenta de Plantino a mediados de 1573 y se reimprimió en 1574) o el tratado educativo del Dictatum Christianum (libro impreso por Plantino en 1575, pero cuyo texto definitivo ya estaba listo para su publicación en 1574) constituyeron un bálsamo para el ánimo desmoralizado de su autor, del mismo modo que también debieron serlo para aquel otro espíritu abatido, o velo mísero y doliente, que era por aquellos días el capitán Aldana.

Porque la pena de Aldana halló en la de Montano "la compañía / del alma / de algún caro y dulce amigo, / con quien hice común acá mi suerte" ${ }^{107}$ Es prácticamente seguro que el poeta pasó en la villa de Amberes los siete meses de convalecencia por la herida sufrida en el asedio de Alkmaar, es decir, de octubre de 1573 a abril de 1574, y aun los meses que siguieron hasta su incorporación al ejército de Holanda a mediados del verano de ese año. Allí, en Amberes, durante el tiempo que duró su recuperación, Aldana tuvo la oportunidad de frecuentar el círculo literario de la Accademia dei Confusi y de participar en sus actividades, como lo demuestra su contribución al bloque poético preliminar de la obra del fundador del grupo, Stefano Ambrogio Schiappalaria, titulada La Vita di C. Julio Cesare, publicada en 1578 (con licencia de impresión de marzo de 1576) pero finalizada desde $1574 .{ }^{108} \mathrm{Y}$ allí, en Amberes, probablemente durante aquellos meses de reposo y reflexión, separado de las armas temporalmente e inclinado por entero al estudio y la escritura, Aldana debió de acercarse como nunca a la persona y al magisterio de Montano, en cuyas tristezas y aspiraciones descubriría el poeta el reflejo de las suyas, y cuya obra, sobre todo la producida en esas fechas, iba a señalarle los caminos de la contemplación de Dios y el retiro del mundo que recorrería pronto su poesía futura. ${ }^{109}$ Es cierto que, en ese preciso momento en que Aldana

105. Carta de Arias Montano a Gabriel de Zayas, 14 de abril de 1574, en CODOIN, tomo XLI (1862: 304).

106. De Benito Arias Montano a don Pedro Vélez de Guevara, vv. 122-124, en Pozuelo Calero (2011).

107. Son versos del soneto "El ímpetu crüel de mi destino", vv. 9-11, en Aldana (Poesías castellanas completas, pp. 391-392).

108. Véase Beck (1985: 216) y Ramos (2018: 129-135).

109. Para las huellas de las Divinas nupcias en Aldana, véase Gómez Canseco (2007: 152-160); 
se reencontró con Montano, el respetado y valeroso capitán de infantería aún estaba lejos de repudiar su existencia mundanal o de someterse al radical discernimiento entre el errado camino de la milicia y la anehalada beatitud de la vida retirada, ${ }^{110}$ pero también lo es el hecho de que habría de constatar en breve y en apenas unos meses lo que él mismo llamará "la baja condenación de mi ventura", es decir, el dominio del castigo sobre el premio "dentro el infierno del común trafago, / que siempre añade un mal y un bien nos quita". ${ }^{111}$

La perversa y acumulada sucesión de desgracias por las que Aldana se vio arrollado al poco tiempo de probar, a costa de su sangre, lo sinsabores de su oficio, y que precipitarían su consabida deriva anímica y crisis espiritual, se dieron justo cuando el poeta trabó verdadera amistad con Montano y han sido hasta el día de hoy totalmente desconocidas. El primer revés le llegó al hispanoflorentino en forma de noticia: la de la muerte de su hermano Hernando de Aldana, militar como él, en la provincia rebelde de Holanda, la cual traía, inevitablemente, no solo el dolor lógico por la pérdida de un ser querido, sino también el recuerdo de una desconsideración inaceptable por parte del Gran Ducado de Toscana y la ocasión de remediarla, esto es, la exclusión de Francisco a la muerte de su padre de una pensión anual de ciento cincuenta escudos que la ciudad de Florencia había concedido en 1571 a sus hermanos Hernando y Cosme de Aldana por los buenos servicios de quien fuera durante dieciséis años castellano de la fortaleza de San Miniato. Como era de esperar, el descubrimiento de semejante desprecio minó el orgullo y las ambiciones de Francisco, que no tardó en escribir al príncipe de Florencia para transmitirle su pesar y desconcierto, "pues accá no bivo con otro nombre q[ue] de criado dessa sereníssima casa, y solamente estoy como exercitándome y abilitándome en las ocasiones de onra para su servicio. Suplico a V[uestra] A[lteza] con el encarecimiento q[ue] puedo sea servido mandarme declarar por qué padesco esta desgracia". ${ }^{112}$ Tres ańos después, al conocer la muerte de su hermano mayor, Aldana podía suplicar de nuevo a Francisco I de Médici que se le reconociesen sus servicios, lo cual hizo a través de la siguiente carta inédita:

para las del Dictatum Christianum, véase Lara Garrido (2000a). Con todo, cabe tener muy en cuenta las convincentes observaciones de Sergio Fernández López (2018: 67 y 74), quien defiende que el encuentro y acercamiento entre Aldana y Montano "debió de facilitarlo el hecho de que ambos profesaran una misma espiritualidad, que ya se encontraba en Aldana desde muy joven", esto es, una religiosidad franciscana "afín al misticismo que exhiben algunas obras de Arias Montano". Desde esta premisa, puede asignarse a la atracción de Aldana por la figura de Montano la celebérrima frase de Pascal, de honda raíz agustiniana, que dice: "Console toi, tu ne me chercherais pas si tu ne m'avais trouvé” (Pensées, 919 [553]), véase ed. Lafuma, p. 379).

110. Véanse las penetrantes disertaciones de Lara Garrido (2000b) sobre esta cuestión.

111. Carta para Arias Montano, vv. 11-12 y 14, en Aldana (Poesías castellanas completas, p. 438).

112. Carta de Francisco de Aldana a Francisco I de Médici, 9 de mayo de 1571, en Archivio di Stato di Firenze, Mediceo del Principato, 560, f. 380r; véase Nievas Rojas (2020: 203-204). 
Después de las heridas y desventuras q[ue] passé en Olanda sobre Alquemar fue Dios servido llevarse a mi hermano Hernando, criado de V[uestra] A[lteza], y porque en su muerte quedó la pensión y merced que V[uestra] A[lteza] le hizo de ciento y cinquenta ducados el ańo, vaca, y en la escritura de la dicha m[erce]d se contiene heredarse de hermano a hermano, me pareció por esta traer a V[uestra] A[lteza] a la memoria q[ue] no por estar yo ausente desmeresco el bien q[ue] por presentia merecieron mis hermanos, pues donde quiera q[ue] estoy solo me onro con el nombre de criado de la sereníssima casa de V[uestra] A[lteza], y voy cobrando desta manera experientia y méritos para sabelle servir, y assí suplico a V[uestra] A[lteza] la dicha pensión, pues ha de caer en hermano sea haziéndome $\mathrm{m}$ [erce]d della, para que no me sienta escluydo de la memoria de mi s[eñ]or, cuya serenísima persona $\mathrm{N}$ [uestro] S[eñor] guarde y en mayores estados acreciente como por mí su criado se desea, de Bruselas, 24 de abril de $1574 .{ }^{113}$

Fijarse en la fecha de esta carta es importante ya que pone de manifiesto que Aldana la escribió el mismo día que partió de Bruselas con aquella instrucción en la que Requesens le instaba para que, en representación suya, buscara a los soldados amotinados allá donde "estuvieren", procurando "hagan alto donde quiera que les tomase sin hacer desórdenes" ${ }^{114}$ Por esa instrucción, de la que Rivers no tuvo noticia y de la que apenas se ha sacado algún provecho desde su descubrimiento en 1981, ${ }^{115}$ se entendía que Aldana, una vez repuesto de su herida, había recibido la delicada comisión de mediar con las tropas españolas que se amotinaron después de la victoria alcanzada en la batalla de Mook, pero en absoluto podía sospecharse bajo qué circunstancia personales la llevó a cabo ni percibir la amargura que suponía ocupar una posición tan ingrata, pese a dimanar de la confianza de las más altas esferas del gobierno. Existe un testimonio, único y de un sentido enormemente tragicómico, que da perfecta cuenta de esa difícil tesitura en la que el nuevo gobernador de los Países Bajos puso a Aldana. El relato, desconocido por la crítica aldanista, conecta con el documento anterior y viene de parte de una fuente considerablemente autorizada y coetánea como Antonio Trillo, testigo ocular y autor de una historia de las guerras de Flandes escrita cuando aún no habían pasado quince años de la deshonrosa entrada de las tropas amotinadas en Amberes. Explica Trillo:

Pero ellos [los soldados] no pararon hasta Arentales, y estando allí, les embió el Comendador mayor un recaudo con el capitán Aldana, y lo que la suma del recaudo era fue ofrecer de treinta y siete pagas las quinze, y que las demás se las pagarían dentro de quatro meses. Oyeron al capitán con mucho silencio, y aunque estavan enojados, le respondieron con mucha gracia y donayre. Y para que se entienda la respuesta, es de saber que el capitán Aldana era hombre eloquente y de muy elegan-

113. Archivio di Stato di Firenze, Mediceo del Principato, 661, f. 268r.

114. Archivo General de Simancas, Estado, leg. 559, f. 33.

115. Ruiz Silva (1981: 20-22). 
tes palabras, y sobre todo eccelentísimo poeta. De modo que, estando toda la infantería junta en un esquadrón en la plaça, y puesto Aldana en una ventana, hizo su razonamiento muy concertado. Y los soldados, después de averle escuchado, viendo que todo se resumía en solas quinze pagas, y estando Aldana aguardando la respuesta, respondió un soldado, que no devía ser poco chocarrero: "Señor Aldana, no emos entendido lo que ha dicho; buélvalo a dezir otra vez, y para que lo entendamos, dígalo en copla”. Levantóse con el donayre tan gran grita y risa entre los soldados, que el capitán Aldana, haziendo del buen compañero, se rio mucho también como ellos, y baxándose de su ventana dio la buelta a Ambers a dar cuenta al Comendador mayor de Castilla de lo que en Arentales le avía pasado, y contando el donaire fue en Ambers muy reído. ${ }^{116}$

Hubo risas, en efecto, pero también mucha vileza y pesadumbre. Es innegable que la anécdota trasluce otra experiencia desgraciada en la vida de Aldana, pues ni siquiera el alto aprecio de que gozaba el poeta entre los soldados logró impedir que estos irrumpieran en Amberes el 26 de abril, quedando resentida la autoridad del comendador, socavada la confianza de los regnícolas leales y más afianzada que nunca la rebelión. Allí mismo, entre los disturbios del motín y las duras negociaciones de las que Aldana era parte imprescindible, el poeta se vio acompañado de su amigo Montano y de su protector Chiappino Vitelli, quien también andaba en trato con los amotinados por tener, como decía Requesens, "crédito y ser bienquisto" de la nación española. ${ }^{117}$ Merece la pena recuperar en este punto otro momento tragicómico que se dio durante estas alteraciones en Amberes de la soldadesca cansada y que tiene a Montano y a Vitelli como protagonistas. Se trata de una anécdota referida por Requesens a Zayas en la que se adivina la figura de Aldana y su complejísima y lamentable situación, a caballo entre la malicia, el cinismo y la bajeza del soldado y la participación afectiva, sensible, virtuosa, del humanista. Escribe Requesens:

No quiero dejar de decir que, estando nuestro amigo Arias Montano con grandísima congoja de estos desórdenes, dijo con lágrimas a Chapín Vitelo: "qué quiere V. $S$. que no me fatigue, pues entre otros dańos han malparido por estos alborotos más de trescientas mujeres en la villa de Anvers". Y le respondió Chapín sin ninguna pesadumbre que no importaba nada, que a trueque de ello quedarían más de seiscientas preñadas. Y el buen Arias Montano se afligió de nuevo viendo decir donaires en este tiempo. ${ }^{118}$

116. Trillo (1592, II: 26v-27r).

117. Ver carta de Luis de Requesens a Felipe II, 30 de abril de 1574, Archivo General de Simancas, Estado, leg. 557, f. 124.

118. Carta de Luis de Requesens a Gabriel de Zayas, 15 de mayo de 1574 , en González Carvajal (1832: 133), doc. núm. 2. 4. El 17 de mayo, el vicario general de Malinas, Maximilian Morillon, le contaba al cardenal Granvela: "Le Padre Trigosa et Arias Montanus ont esté mal et ignominieusament tractés des mutinés", en Correspondance du Cardinal de Granvelle, tomo V (1886: 94). Y el 17 de noviembre, al referirse a Montano, Requesens escribirá a Juan de Zúñiga: "los soldados 
Fue entonces, en medio de aquella insufrible coyuntura en la que Aldana debía empatizar con las mismos hombres que descorazonaban a su amigo Montano, cuando el poeta hubo de recurrir a su destreza como leal servidor valiéndose de sus lazos de dependencia con Vitelli, máximo representante de los intereses toscanos en las guerras de Flandes, para que intercediera en su favor ante la corte medicea, como se aprecia en esta carta, también inédita, que envió el marqués de Cetona desde Amberes a Francisco I de Médici:

È morto in Olanda Ernando di Aldana, figliuolo del castellano Aldana, et è restato il cap[ita]n Francesco suo fiello, il quale fa professione di ser[vito]re di V[ostra] $\mathrm{Al}[\mathrm{tez}] \mathrm{za}$ et di essere nato, et allevato in suo servitio, et perché per la morte di Ernando di Aldana è vacata una pensione della quale V[ostra] Al[tez]za la fece donativo, per la bona servitù di suo padre, supplica il cap[ita]n Francesco a V[ostra] $\mathrm{Al}[\mathrm{tez}] \mathrm{a}$ che la vogli transferire in lui, il quale per essere stato lungo tempo nel servitio medesimo, et facendo professione di sua creatura et ser[vito]re che V[ostra] Al[tez]za resti servita di concedergliela in sua vita, non havendo egli altro pensiero che di vivere, et morire sotto l'ombra sua, et perché è gentil'homo molto valoroso et di molto servitio, et di quelli veramente che V[ostra] Al[tez]za ne pò fare fondamento sicuro nelle occasioni di servirsene, ho voluto con questa mia pregare quanto più humilmente, e strettam[en]te posso, che la gli ne vogli far gratia. ${ }^{119}$

Increíblemente, ni a esta carta de Chiappino Vitelli ni a la de Aldana contestó la corte florentina. De ahí que un mes y medio más tarde, ante la falta de reconocimiento y estima por parte de sus señores, el poeta insistiera una vez más con otra misiva sobre el mismo asunto, más directa que la anterior, y depositaria de una reclamación y protesta indisimuladas. Escribió Aldana en carta fechada en Amberes a 15 junio de 1574:

Por otra mía favorecida con carta del marqués Chapín Vitello supliqué a V[uestra] A[lteza] que la renta de ciento y cinquenta escudos que tenía mi hermano Hernando de Aldana, q[ue] Dios tenga en el cielo, por m[erce]d de V[uestra] A[ltez]a después de la muerte del castellano sucediesse en mí, atento q[ue] por hallarme yo en aquel tiempo ausente no se hizo en dicha renta mentión de mí, puesto que es previligiada en la sucessión de hermano a hermano. De nuevo suplico a V[uestra] A [lteza] se acuerde deste su criado q[ue] por accá tiene, onrado y adelantado con tal nombre, y los méritos ganados en la ausentia no sean parte para que V[uestra] A[lteza] deje de hazerme la $\mathrm{m}$ [erce]d que mereciera presente, pues todo es para habilitarme más en su servi[ci]o, y no por esso dexo de ser hijo del mismo, en cuya consideratión se hizo la merced, y tan criado de la sereníssima casa de V[uestra]

españoles están muy mal con él porque él está muy mal con sus desórdenes, y quiere como a su vida la gente del país", en Instituto de Valencia de Don Juan, envío 67, caja 90, doc. núm. 229 (carta citada en Macías Rosendo 2008: 120).

119. Carta de Chiappino Vitelli a Francisco I de Médici, 28 de abril de 1574, en Archivio di Stato di Firenze, Mediceo del Principato, 651, f. 256r-v. 
A[lteza] como el q[ue] más lealmente la sirve. Mi hermano murió, y vacó dicha renta, V[uestra] A[lteza] me haga $\mathrm{m}$ [erce]d della pues sucede en hermano, q[ue] no la desmeresco por ninguna vía. ${ }^{120}$

Tampoco esta vez hubo respuesta. Tras una búsqueda minuciosa, concienzuda, insistente y extensa en diferentes archivos, es posible afirmar, aun a riesgo de incurrir en una falacia ex silentio, que no hubo respuesta proveniente de la corte medicea. Todo parece indicar, pues, que esta pérdida de favor de quienes habían de ser sus primeros y postreros señores debió de dejar en Aldana la impresión certera de su propio desamparo. Por si fuera poco, un infortunio más aún habría de acaecerle en las próximas semanas. Los detalles del suceso permanecen en la sombra todavía; ahora bien, la correspondencia entre Requesens y Chiappino Vitelli, y algunas alusiones vertidas tanto por Cosme como por Francisco en sus poemas, permiten vislumbrar un incidente que afectaría a la carrera militar del poeta y, tal vez, al tiempo total que este habría de pasar finalmente en los Países Bajos.

El 24 de junio, Requesens contestaba a una carta (hoy perdida) de Vitelli que "tendré mucha cuenta con lo que toca al capitán Aldana, pues demás de sus servicios es para mí mucha prenda mandallo V. S. tan encarecidamente". ${ }^{121}$ Como puede observarse, es un hecho documentalmente constatado que el marqués de Cetona siguió velando por los intereses de Aldana a pesar del abandono por parte de la gran casa florentina que venía padeciendo su protegido. Seguramente gracias a la mediación de Vitelli, Aldana pudo conservar su compañía cuando Requesens acometió la reforma del Ejército en el mes de julio; pero no logró evitar el tifernate que Aldana se viera salpicado por un conflicto que, con toda probabilidad, le acabó costando el cargo de teniente de la artillería, así como sus opciones de ascenso o recompensa inmediata a sus más de veinte ańos de servicio. Estos supuestos parten de la carta que Requesens escribió a Vitelli el 14 de julio:

Mos. de Turlón me ha venido a decir que ahí había sucedido cierto desorden en la artillería, y que había mandado V. S. prender algunos gentiles hombres della, y que la causa desto fue una orden que dio el capitán Aldana; y hame pedido el dicho Turlón que nombre por sus tenientes a los que me ha dado en la memoria que será con esta, y yo no he querido hacer provisión ninguna hasta saber de V. S. lo que ha pasado, pues por su orden sirve el capitán Aldana el dicho cargo. ${ }^{122}$

120. Carta, también inédita, de Francisco de Aldana a Francisco I de Médici, 15 de junio de 1574, en Archivio di Stato di Firenze, Mediceo del Principato, 662, f. 346r.

121. Carta de Luis de Requesens a Chiappino Vitelli, 24 de junio de 1574, en Nueva CODOIN, tomo III (1893: 97).

122. Carta de Luis de Requesens a Chiappino Vitelli, 14 de julio de 1574, en Nueva CODOIN, tomo III (1893: 379). Ninguna de las cartas de Requesens a Vitelli ha sido incorporada a los estudios biográficos sobre Aldana, pese a estar publicadas desde finales del siglo XIX. 
Lamentablemente, nada se ha podido averiguar acerca del problema que refiere Requesens en esta carta. Ahora bien, resulta muy difícil rehuir de la creencia de que tal vez estemos ante ese ignorado personaje que, en palabras de Rivers, "intrigaba contra Aldana, quizá haciendo demorar su traslado, quizá impidiendo que conservara su ascenso al grado de general de artillería". ${ }^{123}$ Aunque Rivers errara al apuntar la categoría militar del poeta (véase la nota 92), no se equivocó al acudir a los versos en los que Cosme afirmó que "un odio mortal varios afectos / movió para impedille el alto grado / en que se vio servir", ${ }^{124} \mathrm{o}$ a los que escribió el mismo capitán Aldana en su Carta para Arias Montano: "y callaré las causas de interese, / no sé si justo o injusto, que en alguno / hubo por que mi mal más largo fuese" (vv. 28-30). ${ }^{125}$ A la luz de la carta que Requesens envió a Vitelli, parece probable que tras esa enemistad que, según dice Cosme y subraya Rivers, "fue llevada a juicio hasta al mismo Rey de España", ${ }^{126}$ se halle el nombre de Louis de Blois, señor de Trélon, general de la artillería del ejército realista (desde el 28 de marzo de 1574) ${ }^{127}$ y miembro destacado de la aristocracia fronteriza entre Francia y los Países Bajos, ${ }^{128}$ quien impediría que Aldana mantuviera su cargo de teniente de la artillería, y tal vez quien alargó, en destino tan poco atractivo ya, su estancia flamenca. Sea como fuere, lo cierto es que la carta de Requesens nos deja entrever un incidente decisivo en la carrera militar del hispanoflorentino, un episodio negativo más que viene a sumarse a la serie de desdichas que el poeta hubo de afrontar entre los meses de abril y julio de aquel annus horribilis de 1574. Así, pues, la muerte de su hermano Hernando, su caída en desgracia ante la corte florentina, su incómoda y delicada posición frente a los amotinados y su estancamiento en el escalafón de la milicia son fenómenos que sembraron de amargura este periodo "de negrísima desesperanza" de la vida de Aldana. ${ }^{129}$ Solo desde esta nueva atalaya de intelección se dimensiona y se comprende cabalmente que, el 31 de julio, Aldana recurriese al "atrevimiento" de escribir al duque de Alba para comunicarle su deseo de abandonar los Países Bajos y servirle en España, mostrando, en aras de su supervivencia y para reparar su orfandad, la misma sumisión al Duque y la misma entrega a las dinámicas de favor y obligación de los modos clientelares que había manifestado el año anterior su amigo Montano:

123. Rivers (1953: 517$)$.

124. Cosme de Aldana (1587: 21).

125. Aldana (Poesías castellanas completas, p. 438).

126. Rivers (1953: 517 y 526).

127. Gachard (1858: 354).

128. Guicciardini (1581: 504$)$.

129. Y son, desde luego, las razones por las que se preguntaba Rivers (1953: 516-517): "parece que [Aldana] pasó por una verdadera crisis emocional. Cuáles eran todas las causas, además del creciente disgusto que le daba la vida militar, solo se puede conjeturar [...]”. Y más adelante: "cualesquiera que fueran las causas contribuyentes, a nuestro soldado-poeta le sobrevino un periodo de negrísima desespranza”. 
Más respetto tengo a la obligatión de ser criado de V[uestra] Ex[celenci]a que al atrevimiento de escrivirle, pues devo posponer qualquiera cosa a la deuda de ser su hechura. Esta confessaré yo mientras tuviere vida y entendimiento, y no trocaré la ventura de tan buen título a todos los demás en q[ue] puedo acrecentarme; y dado q[ue] los Aldanas no tuviessen como por ynclinatión natural llamarse criados de la Ill[ustrísi]ma casa de V[uestra] Ex[celenci]a, yo particularmente me desdeñaría en ser hombre, no professando el servitio y amor q[ue] se deve al valor y bondad de V[uestra] Ex[celenci]a, a quien con toda humildad suplico me tenga en su memoria para mandarme, q[ue] ninguno bive con desseo tan aventajado, y podré executar los mandamientos de V[uestra] Ex[celenci]a, porq[ue] del mosquetazo q[ue] me dieron en Alquemar quedé, tras siette meses de cama, tan libre q[ue] no me ympide el movimiento. Aquí se hizo la reformatión de los capitanes, y puesto q[ue] se tuvo cuenta en dexarme la compañía, como criado V[uestra] Ex[celenci]a yo todavía determino yrme a Espańa a solo besar las manos a don Fadrique, mi S[eñ]or, y servir a V[uestra] Ex[celenci]a, q[ue] es mi principal fundam[ent]o, con cuyo favor pienso remediar mi vida. ${ }^{130}$

Se desconoce si algún miembro de la casa de Toledo movió hilos desde España para facilitar el licenciamiento del hispanoflorentino de sus servicios en Flandes. Todo apunta a que no, no al menos en 1574, más por las limitadas capacidades de los Alba para maniobrar en ese sentido que por una más que improbable indiferencia de estos frente a las desgracias de Aldana. La erosionada influencia y el escaso crédito con que el duque de Alba regresó a España tras seis años de controvertido mandato y el inesperado destierro de la corte al que fue sometido su hijo Fadrique, acusado de crueldad y corrupción por su gestión de la campaña de Holanda de 1572 y $1573,{ }^{131}$ que comandó personalmente, fueron, a todas luces, factores que debieron menguar las posibilidades de que Aldana se acogiese a la protección de los Toledo. Así, sin horizonte de esperanza alguno, el poeta tuvo que resignarse a la prolongación de una existencia miserable en los Países Bajos por diecinueve meses más, en los que no pudo soslayar la carga de sucesos tan aciagos como la derrota de los españoles en Leiden en octubre de $1574^{132}$ o la propagación en noviembre de un motín entre las tropas de su propio Tercio, cuyas exigencias, como hiciera meses antes, llevó él mismo hasta el gobernador por voluntad de los soldados alterados, "que lo pidieron y nombraron entre todos teniendo concepto

130. Carta de Francisco de Aldana al duque de Alba, 31 de julio de 1574, en Archivo de los duques de Alba, C. 25-24, núm. 128. Rivers (1953: 513-514) tuvo que fiarse de la transcripción publicada en los Documentos escogidos del Archivo de la Casa de Alba (Madrid, 1891). Aquí se sigue la carta original, que no presenta discrepancias con las transcripciones hechas anteriormente salvo en el topónimo (la lectura correcta es "Eutreque", y no "Entreque"), esto es, el nombre de la ciudad holandesa donde se encontraba Aldana cuando escribió la carta: Utrecht.

131. Sobre el áspero recibimiento de los Toledo en la primavera de 1574 y su crisis de confianza con la Corona véase Maltby (2007: 415-440) y Martínez Hernández (2013).

132. La participación de Aldana en el asedio de Leiden se confirma en Mendoza (1592: 256v). 
de su persona y obras". ${ }^{133}$ Bien mirado, no es extraño que los amotinados confiaran en un oficial y gentilhombre como Aldana y se descubrieran ante él, pues le hallaron entonces, como reconocerá con dolor el propio poeta en carta a Requesens, "desabrido de mi desgracia". ${ }^{134}$

También en aquel tiempo Montano hubo de sobrellevar el peso de varias desgracias. Su naufragio personal, como ha demostrado sagazmente Antonio Dávila Pérez, se dio tanto en el acantilado de Escila como en el de Caribdis, es decir, en la política y en la religión, los dos frentes a los que lo había abocado Felipe II. ${ }^{135}$ Por lo que respecta a sus funciones como consejero político, es sabido que la influencia que Montano pudo ejercer sobre Requesens fue objeto de críticas y difamaciones por parte de algunas autoridades como el barón de Champagney, hermano de Granvela, o Maximilian Morillon. ${ }^{136}$ De ahí que Juan de Zúńiga, ante el clima de murmuraciones y recelos que llegó a levantarse en torno a Montano, se viera obligado a salir al paso de semejantes rumores negando en carta a Granvela el, por otra parte, evidentísimo papel político del exegeta: "Con Arias Montano no trata [el gobernador] los negocios de Estado, ni con el otro, que no sé quién es; pero escucha lo que le dicen de lo que oyen por las calles, porque el Arias Montano es hombre de bonísima intención y apasionado por el bien de los de la tierra" ${ }^{137}$ Las acusaciones de las que fue blanco fácil el sabio frexnense como consecuencia de su "molesto oficio" político intensificaron sin duda su ya profundo desasosiego y, por supuesto, su deseo de un retiro lejos de los trampantojos de la corte, tal y como se lo haría saber el propio Requesens a Juan de Zúniga: "el mayor testimonio que este levanta [Champagney] es de Arias Montano, porque está tan lexos de pretender ser de Consejo de Estado que muere por que el rey le dé liçençia de irse a Roma o a su Peña". ${ }^{138}$

Por lo que atañe a sus tareas oficiales en materia de religión, Montano tuvo que hacer frente a las reacciones negativas que había suscitado la problemática

133. Carta de los soldados del Tercio de Italia a Luis de Requesens, 7 de noviembre de 1574, en Archivo General de Simancas, Estado, 560, f. 13 (véase la respuesta del gobernador, a 15 de noviembre, en el f. 14). Sobre la desconocida mediación de Aldana entre los amotinados del Tercio de Italia y el gobierno (los soldados no volvieron a la disciplina hasta el 5 de marzo de 1575) véanse, además, las cartas de Guilles de Berlaymont, gobernador de Holanda, a Requesens, en Archives Générales du Royaume, Audience, 1723/2, ff. 392r (15 de noviembre), 441v (14 de diciembre), 444v (17 de diciembre) y 453r ( 25 de diciembre).

134. Carta de Francisco de Aldana a Luis de Requesens, 23 de febrero de 1576, en Bibliothèque Publique et Universitaire de Genève, Collection Edouard Favre, vol. XXX, f. 195r (transcrita en Rivers 1953: 520-522 y 1957: XLVII-L).

135. Dávila Pérez (2011: 257-262).

136. Véase Morales Oliver (1927: 292-295), Macías Rosendo (2008: 114-115) y Dávila Pérez (2011: 260-261).

137. Carta de Juan de Zúniga a Antonio Perrenot de Granvela, 13 de junio de 1574, en Nueva CODOIN, tomo III (1893: 7).

138. Carta de Luis de Requesens a Juan de Zúniga, 18 de noviembre de 1574, en Instituto de Valencia de Don Juan, envío 67, caja 90, doc. núm. 229 (citada en Macías Rosendo 2008: 115). 
ortodoxia de la Políglota prácticamente desde el comienzo del proyecto y, sobre todo, a partir de la desaprobación inicial de la Santa Sede. En los Países Bajos, el principal detractor de la Biblia Regia, Guillermo Lindano, obispo de Ruremonde, se ocupó largos años en sostener su oposición científica y personal contra Montano y sus trabajos de filología bíblica. La polémica entre ambos eruditos, a la que el profesor Dávila Pérez ha dedicado ya varios estudios, ${ }^{139}$ llegó a tal grado de obstinación y animadversión "que se extendió hasta más allá de la muerte de sus protagonistas", ${ }^{140}$ pero fue en 1574 y 1575 cuando tuvo lugar su mayor fragor y más abierta hostilidad entre intrigas, delaciones y disputas dialécticas. Sin embargo, los ataques más destructivos y preocupantes que "proponían a la Políglota y a su autor como verdaderos judaizantes pagninianos" 141 le llegaron a Montano desde España de la mano del teólogo y catedrático de Salamanca León de Castro, responsable de la atmósfera antihebraísta que había permitido el encarcelamiento en 1572 de fray Luis de León, Martín Martínez Cantalapiedra y Gaspar de Grajal. Si en 1569 y en 1570 León de Castro ya había manifestado públicamente su rechazo a la Políglota montaniana, tomando como espuela argumentativa la creencia de que "todo lo que es letra o que tiene color de aver nacido de rabbinos es [...] cosa descomulgada", ${ }^{142}$ en 1574 , tras examinar la obra, el helenista redobló su ofensiva contra quien, según él, "quer[ía] destruir la Vulgata", ${ }^{143}$ formalizando su denuncia en la corte y ante el tribunal de la Inquisición. Afortunadamente, Montano contó con el apoyo incondicional de numerosos e influyentes amigos frente a la polémica desatada por el maestro León de Castro, como el secretario Gabriel de Zayas en la corte o los profesores Pedro de Fuentidueña y Francisco Salinas en la Universidad de Salamanca. De hecho, Fuentidueña y Salinas, que habían vivido de cerca los procesos contra los defensores de los textos originales de la Biblia y temían que la furia de León de Castro pudiera cobrarse una nueva víctima, intentaron informar a Montano de todos los pormenores críticos y de los argumentos aducidos por el catedrático de griego en su acusación, ya que, teniendo en cuenta los métodos al uso de los tribunales inquisitoriales, "de producirse un interrogatorio sobre la naturaleza del trabajo montaniano en Amberes, la preparación argumental de la defensa se revelaba fundamental ante el desconocimiento propio de la motivación acusatoria contra el reo". ${ }^{144}$ Además, los leales confidentes de Montano no dejaron de advertir a su amigo de que la única forma de frenar los

139. Por ejemplo, Dávila Pérez (2000 y 2009).

140. Dávila Pérez (2015b).

141. Ortega Sánchez (2006).

142. Carta de fray Luis de León a Arias Montano, 28 de octubre de 1570, en Macías Rosendo (1998: 242).

143. Carta de Francisco Salinas a Arias Montano, 13 de julio de 1574, en Macías Rosendo (1998: 329).

144. Ortega Sánchez (2006); véase también Macías Rosendo (1998: 330). 
continuos ataques de Castro pasaba por una nueva jornada del frexnense a Roma, a fin de obtener del Papa una interpretación más amplia del célebre decreto tridentino De editione et usu sacrorum librorum al que tanto se aferraban sus detractores. ${ }^{145}$ Así, pues, gracias a los avisos que le llegaron de España, Montano tomó consciencia de las amenazas que se cernían sobre él, de manera que, a partir del verano de 1574 , comenzó a preparar el terreno para su viaje de vuelta a la corte espańola, al menos oficialmente, aunque su verdadero propósito era hacerlo sólo después de haber recalado en Roma, donde debía defender la metodología filológica empleada en la Políglota y valorar el alcance y daño de las críticas recibidas. Su seguridad, ciertamente, dependía de ello.

El 21 de agosto de 1574, Felipe II concedió a Montano, por fin, la anhelada y tantas veces solicitada licencia para salir de Flandes, ${ }^{146}$ pero el permiso no lo recibió el biblista por lo menos hasta el 9 de octubre, cuando escribió a Zayas para agradecerle la "grande merced" y comunicarle su resolución de "emplear los pocos días que me quedan de vida en procurar la salud de mi ánima, recogiéndome para ello en la Peña o en algún lugar más apartado". ${ }^{147}$ Aunque las pretensiones por parte de Montano de consagrar el resto de su vida al estudio en dichoso apartamiento fueran tan sinceras como siempre, no podían constituir estas por entonces un objetivo realizable a corto plazo, pues el teólogo de Fregenal ya había tomado la decisión de llevar hasta la Santa Sede la causa de su conflicto con León de Castro. ${ }^{148}$ Sí podía, al menos, intentar alargar su estancia entre uno y dos años, como de hecho lo hizo desde su llegada a Roma a principios de julio de $1575,{ }^{149}$ alegando el pretexto, solo cierto en parte, de que allí

145. "También avisava a Vuestra Merced que el remedio que, a mi parecer, tenía este negocio era por vía del Summo Pontífice"; "yo bien entiendo que no podía aver remedio mejor ni más breve que éste, porque con sólo declarar el Papa aquel decreto del Santo Concilio, era todo acabado", cartas de Pedro de Fuentidueńa a Arias Montano, del 7 de agosto y del 5 de noviembre de 1574, en Macías Rosendo (1998: 331 y 346).

146. No se ha descubierto aún el documento oficial que notifica la dicha licencia de Montano. El dato proviene de una carta de Requesens al rey del 9 de enero de 1575: "En 21 de agosto me escribió V. M. la licencia que daba al Doctor Arias Montano para irse a esos Reynos...”, en Archivo General de Simancas, Secretarías Provinciales, leg. 562, f. 6; aquí se cita por González Carvajal (1832: 172), doc. núm. 55, pero véase también una copia de los capítulos de esta carta (conservada en el manuscrito de Estocolmo A902) en Macías Rosendo (1998: 358-359).

147. Carta de Arias Montano a Gabriel de Zayas, 9 de octubre de 1574, en CODOIN, tomo XLI (1862: 310).

148. Antes de comenzar el otoño, Montano ya se había resuelto a ir a Roma; véase la carta de Pedro de Fuentidueña al cardenal Estanislao Hosio del 23 de agosto o la que el 5 de noviembre escribió el prestigioso teólogo al propio Montano, que es respuesta a una carta del 29 de septiembre en la que el sabio de Fregenal informaba de su intención de acudir a Roma, en González Carvajal (1832: 172), doc. núm. 53 y Macías Rosendo (1998: 346-347), respectivamente.

149. Montano pospuso su salida de Flandes hasta la primavera de 1575 (partió a finales de abril o principios de mayo), "porque a la verdad no tiene salud para ponerse en tan largo camino en tan recio tiempo", carta de Luis de Requesens a Felipe II, 9 de enero de 1575, en González Carvajal (1832: 172), doc. núm. 55. 
podría aprovecharse de la "comodidad de bibliotecas raras y copia de hombres estudiosos en todas facultades y lenguas" para "acabar algunas obras que tengo entabladas", ${ }^{150}$ aunque la razón primordial para quedarse en Roma la encontrara Montano en la trascendencia y la gravedad que habían alcanzado las arremetidas contra la Políglota lideradas por Castro, cuyas críticas se habían extendido en la curia pontificia hasta influir en el ánimo de la mayoría de los teólogos.

En efecto, toda la ciudad se llenó del "ruydo" y los "bramidos"151 de León de Castro cuando este presentó en 1575 su denuncia de la Biblia Regia ante el Santo Oficio de Roma. Montano, que no poseía licencia para permanecer en Roma y sí una expresa para volver a España, no pudo sino sentirse abrumado frente a unos acontecimientos que prometían su comparecencia ante el tribunal de la Inquisición, por lo que no tardó en escribir, el mismo día, tanto al Inquisidor General, Gaspar de Quiroga, como a Felipe II, con la intención de informarles y protegerse de lo que "se ha derramado por parte del maestro Castro, que es mucho más que lo se ha sparcido por España, y [...] se está aquí juzgando en particular congregación instituida para esto". ${ }^{152}$ No hay duda alguna de que la idea de un porvenir incierto en Espańa atenazó a Montano, y por ello trazó dos líneas de argumentación paralelas para detenerse en Roma, las cuales fueron presentadas en su correspondencia con la corte de Madrid no de forma simultánea, sino consecutivamente, y, por tanto, con suma habilidad estratégica, como se constata en la carta que el escriturario envió a Zayas el 19 de agosto de 1575:

Yo suplico a v. m. por Dios Nuestro Señor [...] que no interprete carta alguna de cuantas le he escrito de aquí de Roma ni de otra parte a otro fin ni motivo sino al que en ellas declaro, de servir a Dios y a su Iglesia católica [...]; porque de todas mis pretensiones este es el fin: cumplir con mi conciencia y satisfacer a lo que buenos y doctos y gente amiga de la simplicidad cristiana me han escrito, aconsejado, exhortado y aun reñido; que esta conciencia me hace que yo procure no perder el tiempo que pudiera emplear en los estudios para este efecto [...]; y por solo esto he suplicado a S. M. ${ }^{\text {d }}$ rimeramente por licencia para estar aquí hasta dos ańos o año y medio o uno entero, [...] y por solo esto he pedido después la licencia y favor para tratar aquí desta causa que León por solo su consejo ha querido mover. ${ }^{153}$

150. Carta de Arias Montano a Felipe II, 29 de julio de 1575, en CODOIN, tomo XLI (1862: 313). Véase también la petición de Montano a Zayas del 6 de agosto de 1575, con idéntica justificación, en CODOIN, tomo XLI (1862: 314-316). Compárense estas dos cartas con la que Montano había enviado a Juan Moreto el 7 de julio, en la que declara los mismos motivos y argumentos para permanecer en Roma, sin revelar todavía sus verdaderas intenciones: tratar de ampliar la interpretación del Concilio Tridentino sobre la Vulgata y aplacar las acusaciones de Castro, en Dávila Pérez (2002a: 198-201).

151. Carta de Arias Montano a Felipe II, 12 de agosto de 1575, en Macías Rosendo (1998: 435). 152. Carta de Arias Montano a Gaspar de Quiroga, 12 de agosto de 1575, en CODOIN, tomo XLI (1862: 319).

153. CODOIN, tomo XLI (1862: 321-322). 
Debió de ser un golpe duro para Montano recibir la carta que Felipe II le envió el 7 de septiembre como respuesta a la que su capellán real le había escrito el 29 de julio. En ella, el rey instaba a Montano a que regresase inmediatamente a Espańa para encargarse de un asunto arduo y extremadamente fatigoso que en absoluto podía satisfacer al biblista y que de ninguna manera hacía justicia a sus aspiraciones: la corrección y refutación de la primera historia eclesiástica protestante, conocida como las Centurias. He aquí la orden:

[...] yo os diera de buena gana la licencia que pedís, si las cosas que acá ocurren y en que os pienso emplear lo sufrieran, pero son de cualidad, y tan importantes al servicio de Dios Nuestro Señor y de su Santa Iglesia y Religión, que se deben preferir a todas las demás, pues por la mucha satisfacción que de vos tengo os he escogido por una de las personas que han de entender en lo que se ha de escribir contra el libro de las Centurias que los hereges han derramado tan pernicioso como sabéis, que con voluntad y orden de S. S. se han de juntar para esto en Alcalá, y querría yo que se hiciese con la brevedad posible; y así os encargo mucho que os vengáis con la primera comodidad de buen pasage. ${ }^{154}$

No sin desgana y preocupación, a buen seguro, Montano hubo de obedecer la nueva comisión que el rey le había encomendado en España, ${ }^{155}$ aunque trabajó por demorar su partida al menos hasta que Roma se pronunciase sobre la polémica que rodeaba a la Políglota, arguyendo como excusa que deseaba "tener aviso [...] de la resolución y mandato de S. M. ${ }^{\mathrm{d}}$ acerca de lo que yo debo hacer aquí en procurar que se allane lo que el maestro León ha querido revolver y levantar sobre la impresión de la Biblia". ${ }^{156}$ Por fin, el 17 de enero de 1576, la Congregatio Concilii llegó a una conclusión, que resultó opuesta a los intereses de Montano: en cuanto a la primacía de la Vulgata, la curia romana sentenciaba que no se podría modificar nada contrario al texto latino; en relación con la Políglota, la Congregatio daba su aprobación a regañadientes y solo por deferencia a Felipe II, pero desaconsejaba hacerla extensiva al Apparatus. Finalmente, Gregorio XIII se desentendió del problema y delegó la última palabra en la

154. Carta de Felipe II a Arias Montano, 7 de septiembre de 1575, en González Carvajal (1832: 171), doc. núm. 54.

155. "Luego que recibí el mandato de V. M. ${ }^{\mathrm{d}}[\ldots]$, dejados todos los demás propósitos que me parecía ir encaminados al servicio de Dios y de V. M. ${ }^{\mathrm{d}}$, me afirmé en solo el de la obediencia que a V. M. ${ }^{d}$ debo, y no trato de otra cosa que aprestarme para ir a servir en lo que V. M. ${ }^{d}$ me mandare, y con este intento hablé luego a don Juan de Zúñiga, embajador de V. M. ${ }^{\mathrm{d}}$, mostrándole su mandato y pidiéndole consejo y ayuda para mi pasage", carta de Arias Montano a Felipe II, 20 de octubre de 1575, en CODOIN, tomo XLI (1862: 326-227).

156. Carta de Arias Montano a Gabriel de Zayas, 24 de diciembre de 1575, en CODOIN, tomo XLI (1862: 328). El frexnense parece aludir a la falta de respuesta a su carta del 12 de agosto dirigida a Felipe II, un silencio que le valdría para aguantar un tiempo más en Roma, a la espera de contestación. 
Inquisición Española. ${ }^{157}$ Esta sentencia infundió sin duda miedo en el ánimo de Montano, pues no era descabellada la idea de que pudiese sufrir a su regreso algún perjuicio por parte de sus detractores españoles. ${ }^{158}$ Ante este panorama, y casi contraviniendo las órdenes del rey, Montano procuró por todos los medios a su alcance zafarse de sus compromisos cortesanos, y dilató cuanto pudo su estancia en Roma. Así, el 24 de enero de 1576, Montano escribía al cardenal San Carlos Borromeo lo siguiente sobre su más hondo y antiguo anhelo, en busca de protección, así como de algún ángulo apacible, recogido, para su necesidad de estudio:

Io ho consummato con Sua Sa Rma. il proposito mio e grandissimo desio che io ho di ritrarmi a finire la vita in quelli studii ch'io stimo essere utili a me e forse a altri miei fratelli christiani, e quanto travaglio e mi affatico per sbrigarmi de le facende e obligattioni di Corte, io spero in Nostro Signore mi farà alcum dì questa gratia, $\mathrm{e}$ che il mezzo e commodità per usar di quella sarà sotto la protettione di V. S. I. ${ }^{159}$

Mucho más sincero fue Montano con su amigo flamenco Abraham Ortelio, a quien el 28 de febrero dirigió una carta confesándole su desacato para con el rey y sus intenciones de volver a los Países Bajos:

[...] no deseo ni pido ni me preocupo de otra cosa que de una vida privada y ajena a toda ocupación externa, y estoy del todo pendiente de esto y lucho cuanto puedo por librarme de mis deberes cortesanos para, si pudiera conseguirlo, volver cuanto antes a vosotros, o sea, a mí. Y por eso he aplazado hasta ahora mi viaje a España, aunque me han llamado muchas veces; pero yo haré cuanto pueda para lograr lo que pretendo. ${ }^{160}$

Ante la muerte de Luis de Requesens a los pocos días de haber escrito esta carta, Montano no desaprovechó la oportunidad para redactar una estrictamente confidencial para el secretario Zayas, en la que le expresaba su deseo de regresar a Flandes por lo útiles que podrían ser allí sus servicios dadas las nuevas circunstancias:

Digo que habiéndome v. m. de tener ausente de sí, aunque fuese Alcalá, y teniendo muy pocos otros señores en Espańa que me deseen mucho presente, fuera de mis hermanos, hasta que Dios ordene, o que yo muera, o que S. M. ${ }^{d}$ me coloque en otra

157. Rekers (1973: 88).

158. El temor por el destino del frexnense en España se esparció incluso entre sus amistades belgas; véase la carta de Cristóbal Plantino a Arias Montano del 18 de febrero de 1576, en Dávila Pérez (2002a: 324-329).

159. Carta de Arias Montano a San Carlos Borromeo, 24 de enero de 1576, en Tellechea Idígoras (1998: 75).

160. Carta latina de Arias Montano a Abraham Ortelio, 28 de febrero de 1576; aquí se sigue la traducción de Morales Lara (2002: 161 y 163), pero véase también en Rekers (1973: 116). 
cosa que me esté bien para mi vocación, o me dé licencia de retirarme a un rincón, entre tanto me parece que v. m. me terná mejor allí en Flandes, pues tiene un servidor en quien se fiar, que le puede servir en declararle lo que allá pasare, ansí tocante al gobernador como a S. M. ${ }^{\mathrm{d}}$, como al público, y también al particular de v. m. ${ }^{161}$

A pesar de todos sus esfuerzos, y porque "havendomi commandato la maestà del Re mio signore per tre letere sue ch'io vada in Spagna a certi servitii suoi e non potendo scusar questa ubidienza", ${ }^{162}$ Montano tuvo que abandonar Roma el 1 de junio y poner rumbo a la corte española después de ocho largos años de ausencia, los más intensos sin duda de su vida. Partió desalentado, con la firme convicción de que, una vez llegado a su destino, habría de "enfrentarse cuerpo a cuerpo con sus detractores españoles”. ${ }^{163}$ En realidad, como el propio Montano comprobaría estando ya de vuelta en España, el riesgo de un proceso inquisitorial era menor del que todos temían, aunque no por ello podía respirar más aliviado ni bajar la guardia en vista de la pertinaz oposición que León de Castro seguía sosteniendo y que desembocaría en la carta requisitoria que el 9 de noviembre envió el antihebraísta al licenciado Hernando de Vega, del Consejo de la Inquisición, para que Montano diera "razón de sus cosas" ${ }^{164}$ Lo más inesperado y revelador de este momento, por lo que a la presente investigación se refiere, es que, cuando Montano llegó a la corte madrileña el 10 de julio de $1576^{165}$ bajo el signo de una polémica que amenazaba con destruirle, su amigo Aldana se encontraba en la misma corte dando ya razón de sus cosas y pidiendo su propia justicia.

Así es, cuando Montano regresó a España, hacía cuatro meses que Aldana, desvalido y solo, había abandonado Flandes en dirección a Madrid para "ver si puedo cojer algún frutto de veynte y quatro años q[ue] aro la tierra”. Como el propio Aldana confesó a Requesens en una carta escrita apenas unos días antes de la muerte del gobernador, marchó el poeta "destruydo", y aunque ello sería "antes espuela para mi virtud q[ue] freno para detenella", también partió con la increíble determinación de abandonar las armas: "que el hábito de mi soldadesca ya se rompió y me será fuerça procurar otro de más siguridad". Un completo halo de misterio envuelve la forma en que logró Aldana la licencia que ponía fin a sus servicios en los Países Bajos, aunque no menos sorprendente resulta, a poco que se adentre en la realidad militar de la época, el hecho de que Aldana tomase la decisión de renunciar a su oficio. Los estudiosos del Divino hablan, en efecto,

161. Carta de Arias Montano a Gabriel de Zayas, 22 de marzo de 1576, en CODOIN, tomo XLI (1862: 336).

162. Carta de Arias Montano a San Carlos Borromeo, 18 de mayo de 1576, en Tellechea Idígoras (1998: 76).

163. Dávila Pérez (2002a: 341).

164. Carta de León de Castro a Hernando de Vega, 9 de noviembre de 1576, en Conde (1928: 437).

165. La fecha exacta nos la proporciona Montano en carta a San Carlos Borromeo del 28 de septiembre de 1576, en Tellechea Idígoras (1998: 79). 
de licencia, ${ }^{166}$ pero conviene puntualizar, o al menos cuestionar, lo que no deja de ser más que un supuesto sin ninguna base argumentativa. En principio, el enganche militar en el siglo XVI era a perpetuidad, de manera que no existía la jubilación, que en cambio sí se daba en los oficios de pluma. Los soldados estropeados, o inútiles, como se les llamaba a los que ya no podían servir a causa de su invalidez por heridas de guerra, pasaban a servir en castillos o eran recibidos en conventos, pero no perdían la condición militar hasta la muerte. Los permisos, que eran las licencias, constaban en las hojas de servicio como interpolaciones y rara vez se concedían, aunque eran más corrientes en el caso de los oficiales nobles, siendo frecuentes para hacerse cargo de una herencia, rehacer la fortuna familiar o para cumplir votos religiosos, así como para procurarse alguna merced en la corte. ${ }^{167}$ ¿Cuál de estas posibilidades se debe aplicar al caso de Aldana? Difícil es establecerlo, aunque podría aventurarse lo siguiente: Aldana, desilusionado con la vida soldadesca en general y, sobre todo, impresionado por la desvergüenza y deshonor de los amotinados, que vestían su mismo uniforme y entre los que medió con riesgo de su vida, decidió cambiarlo por el más limpio, cómodo y seguro de castellano, como lo confirma su solicitud del año siguiente de la alcaidía de la fortaleza de San Sebastián. Por esta razón Aldana se iría a España, para reclamar por merced un ascenso significativo ante la corte, que era el motivo más frecuente, como acaba de apuntarse, por el que se solicitaban y concedían licencias, que debía expedir siempre el gobernador y capitán general; el problema es que Requesens murió el 5 de marzo sin haber designado sucesor y el gobierno recayó en el Consejo de Estado, órgano colegiado sin competencias para expedirlas. Así, pues, labrando aún en el terreno de la hipótesis, podría presumirse sin vacilación que Aldana debió de partir para España sin la preceptiva licencia y de ahí que, como se verá enseguida, hubiera de ser perdonado por el rey a causa del abandono de su puesto sin el permiso reglamentario. Sea como fuere, lo cierto es que supone una tarea espinosa dar con la respuesta acertada, y más aún si se atiende solo a la expresión que utilizó el poeta en la primera frase de su carta a Requesens: "Muéveme el ser cristiano y soldado, después de aver recebido el jubileo, a escrivir a V[uestra] Ex[celenci] a estos pocos ringlones". ${ }^{168}$ La pregunta que resulta de esta lectura es obvia: ¿empleó Aldana el término "jubileo" con el mismo significado que el de "licencia", o quizá -y he aquí un horizonte especulativo tan extraño como sugerente- se refería a la merced religiosa que el Papa podía conceder en ocasiones especiales, como la del Año San-

166. Baste con Rivers (1953: 523) y Lara Garrido (1985: 29).

167. Parker (2014: 253). También me valgo de las conversaciones mantenidas con un historiador militar de la talla de Juan Luis Sánchez, a quien agradezco sus múltiples y generosas aportaciones al tema a raíz de mis preguntas.

168. Carta de Francisco de Aldana a Luis de Requesens, 23 de febrero de 1576, en Bibliothèque Publique et Universitaire de Genève, Collection Edouard Favre, vol. XXX, f. 195r (transcrita en Rivers 1953: 520-522 y 1957: XLVII-L). La cursiva es mía. 
to de 1575? Ineludible es señalar en este punto que una de las varias razones oficiales- que Montano adujo para ir a Roma en 1575 fue "su deseo de ganar el jubileo de este año santo, porque de mucho atrás deseaba hallarme aquí en tal tiempo" ${ }^{169}$ ¿Podría existir alguna conexión, absolutamente ignorada, entre el viaje de Montano a Roma y la obtención del jubileo por parte de Aldana? Insinuadas las conjeturas y sin más datos, abstenerse de responder parece, de momento, lo más prudente.

Sí puede afirmarse, en cambio, que Aldana llegó a la corte de Madrid hacia finales de marzo de 1576 con la idea, como se ha dicho, de abandonar la milicia activa, pero también con la certeza de que, cualesquiera que fuesen sus pretensiones, estas dependían enteramente de la defensa y reivindicación de su persona ante Felipe II y, en última instancia, de la clemencia del propio rey. Tal vez se hallara Aldana en una situación embarazosa por haber salido de los Países Bajos sin la licencia debida; aunque lo más seguro es que perseguieran al poeta ciertas acusaciones que desconocemos, animadversiones y desencuentros vividos durante su última etapa en Flandes que ponían en tela de juicio su honor, su dignidad y, sobre todo, los servicios de una trayectoria impecable entregada a las guerras que, según él mismo, sostenían los designios de la Monarquía Hispánica. ${ }^{170}$ Como era de esperar, Cosme no pasó por alto la comparecencia de su hermano en el que ha sido hasta hoy el único testimonio que teníamos del caso:
Vínose a las Españas, contrastando
al furor del crüel y sus enojos
a do, con gran valor notificando
la causa, de su rey puesto a los ojos,
con su razón presente fue sacando
de más alta fortuna los despojos. ${ }^{171}$

Sustancia de realidad y apoyo dispensa a estos versos la siguiente carta desconocida que Guilles de Berlaymont, gobernador de Holanda, dirigió el 6 de agosto al Consejo de Estado de Bruselas cuando, por medio del capitán de infantería y amigo del poeta Felipe de Beaumont, supo que el caso de Aldana dependía de una relación en términos favorables sobre los servicios del hispanoflorentino emitida por la administración flamenca:

169. Carta de Arias Montano a Gaspar de Quiroga, 12 de agosto de 1575, en CODOIN, tomo XLI (1862: 317). Y lo mismo en cartas de Montano a Moreto y a Felipe II, del 29 de julio y del 7 de julio, respectivamente, en Dávila Pérez (2002a: 199) y CODOIN, tomo XLI (1862: 312).

170. Lo expresará Aldana por estas fecha a través de la figura alegórica de la Guerra y recuperando el famoso argumento heraclitiano, en las Octavas dirigidas al rey don Felipe, nuestro señor: "Soy la madre de los Césares famosos, / reina de los antiguos Tolomeos, / señora de los casos venturosos, / valedora total de los deseos; / los tronos y los cetros más gloriosos / mis ornamentos son y mis trofeos", vv. 97-102, en Aldana (Poesias castellanas completas, p. 401).

171. Cosme de Aldana (1587: 21). 
Ayant esté requiz par le seigneur don Phelipe de Beaumonte que pour estre le capitaine Francisco de Aldana en Espaigne en poursuyte pour avoir pardon de sa $\mathrm{Ma}$ jesté et qu'il ma faict scavoir que l'entier remède de son affaire deppend de la srealle relation et bon rapport que à Vous, messeigneurs, plairoit de faire de luy vers sa Majesté escripvant à icelle. Je voulsisse interceder à ceste fin envers Vous. Et cognoissant ledict Aldana pour ung bon et vaillant soldart, s'ayant bien acquité en plusieurs endroictz et faictz darmes, je nay peu de laisser daccompaigner en cours de ceste présent courrier pour Vous prier trèshumblement qu'il vous plaise, Messeigneurs, escripre à sa Majesté si favorablement qu'il puisse obtenir l'effect de sadicte poursuyte en faisant la relation comme sa valeur et vaillantise le méritent en quoy l'obligerez à jamais de continuer au service de sadicte Majesté et de Vous Messeigneurs, et a moy sera faveur bien singulier. ${ }^{172}$

Es muy posible que Montano, quien justo por esos días había podido entrevistarse con el rey y hablar hasta "hore otto in quatro volte à bocca", ${ }^{173}$ conociera de primera mano el caso por el que estaba siendo procesado su gran amigo y que también intercediera por él, hecho que explicaría que Aldana se atreviese a aludir al tema -silenciándolo- en la epístola en verso que al año siguiente dedicó al escriturista: "y callaré las causas de interese, / no sé si justo o injusto, que en alguno / hubo por que mi mal más largo fuese". ${ }^{174}$ No obstante, aun contando con los informes positivos de Bruselas y probablemente también con los de Montano, el caso de Aldana no debió de empezar a resolverse por lo menos hasta finales de año, pues el 24 de octubre el poeta aún declaraba en la dedicatoria que puso al frente de las octavas para Felipe II "estar al presente en esta corte sperando lo que dispusiere la clemencia de VMd sobre siete meses que ha que pido mi justicia”. ${ }^{175}$ A la luz de esta tesitura, resulta evidente que Aldana compuso esa "amplia teoría defensiva de las fronteras peninsulares" ${ }^{176}$ que representan sus octavas al rey buscando su absolución y el reconocimiento de su valía, no solo como experto militar, sino también como consejero político del cual

172. Carta de Guilles de Berlaymont a los señores del Consejo de Estado de Bruselas, 6 de agosto de 1576, en Archives Générales du Royaume, Audience, 1723/4, f. 236r.

173. Carta de Arias Montano a San Carlos Borromeo, 28 de septiembre de 1576, en Tellechea Idígoras (1998: 79). Montano debió de ser recibido en audiencia real poco después del 25 de julio, pues ese día el secretario Zayas solicitó a Felipe II que "sea servido de dar licencia para que [Montano] vaya a besar las manos de V. M., que yo creo que holgará mucho V. M. de oírle y mandarle mostrar la librería y orden de estudios que hay en ese convento”, en González Carvajal (1832: 172), doc. núm. 56.

174. Carta para Arias Montano, vv. 28-30, en Aldana (Poesias castellanas completas, p. 438). Aldana parece seguir a su maestro en este silenciamiento voluntario de los males sufridos acudiendo a su oda a Pedro Vélez de Guevara: "Quos uita fluctus post mea pertulit, / impulsa rerum casibus asperis, / formidat usa et mens referre, / et refugit memorare carmen", vv. 45-48, en Pozuelo Calero (2011).

175. Carta dedicatoria de Francisco de Aldana a Felipe II, 24 de octubre de 1576, en Martínez López (1997: 44).

176. Hernando Sánchez (2016: 144). 
podía servirse confiadamente Felipe II. Con sus particulares "advertimientos", Aldana se postulaba como agente del rey para ganar su favor, emulando lo que hiciera Montano años atrás al ofrecerse y operar como informador secreto y asesor de la monarquía española.

Pese a su delicada coyuntura y su desgarro moral, Aldana debió de mantenerse firme en su convicción de que los veinticuatro años de servicio continuado por Italia, Flandes, Levante y Berbería merecían una recompensa acorde con su carrera. Gracias al descubrimiento de una carta de Fadrique de Toledo escrita desde su confinamiento en Tordesillas dirigida al propio Aldana, se puede asegurar que, en algún momento de finales de 1576 (noviembre o diciembre), se propuso como solución para el caso del hispanoflorentino que este conservara su rango de capitán y que se le pusiera al mando de una compañía, propuesta que Aldana rechazó de plano por verla claramente encaminada a menoscabar su honra y por considerarla, como no podía ser de otra manera, indigna de sus méritos. En dicha carta, Fadrique le manifestó su apoyo y lo animó a que perseverara el tiempo que hiciese falta hasta alcanzar su primitiva intención, que no era otra que la de procurarse un hábito de mayor seguridad que el de la soldadesca, quizá con el título de castellano o, tal vez, de no conseguirlo, profesando como religioso. Escribió el futuro y desdichado IV duque de Alba:

En mucho cargo os soy, señor, por el contentamiento que me havéis dado con vuestra carta, aunque quisiera que vuestros negoçios dieran lugar a que me scriviérades le teníades, porque cierto siento el veros sin él como cosa propia y mucho más ser en occasión que no os puede aprovechar en vuestras pretensiones la voluntad con que me he yo de emplear en todo lo que os toccare. Será menester que lo remedie vuestra prudençia con ayudaros de la paciençia que es menester para sufrirlo. Ha me pareçido muy bien la resolución que havéis tomado en no encargaros de compañía hasta tener acabado el negoçio con que venistes a Spaña, porque en las cosas que tocan a onor no se ha de tener consideración a ninguna otra que no sea esta la principal. Al Duque y al Prior escrive en la conformidad que me pidís, y con el encarescimiento y calor que haré todo lo que supiere que puede aprovecharos, y assí será que me aviséys de lo que entendiéredes que puedo hazer por vos para que se ponga por obra y se os dé la satisfación que de mi parte se debe a vuestra voluntad, porque a esta no faltaré con la persona y con la hazienda. ${ }^{177}$

Por el desconocimiento que demuestra Fadrique sobre la suerte de Aldana a la altura del mes de febrero de 1577 , se infiere que esta carta debe ser respuesta a una escrita por el poeta antes de que se le diera el cargo provisional y fugaz de la tenencia de la fortaleza de San Sebastián y, por supuesto, antes de que fuera escogido, seguramente por mediación del duque de Alba, para la arriesgada comisión de espionaje en el norte africano que tuvo que llevar a cabo junto con el

177. Carta de Fadrique de Toledo a Francisco de Aldana, 20 de febrero de 1577, en Biblioteca del campus Barri Vell de la Universitat de Girona, Ms. Aldana, s. f. 
aventurero Diego de Torres, estipulada tras la célebre entrevista de Felipe II y Sebastián de Portugal en el monasterio de Guadalupe en la navidad de 1576, donde ambos monarcas trataron acerca de la empresa que acabaría con la vida del rey portugués y con la de Aldana. ${ }^{178}$ Partió el poeta hacia África en enero, seguramente desconcertado ante su nuevo papel de informador y espía; $y$, desde luego, partió con el amargo convencimiento de que sus pretensiones no habían sido valoradas ni mucho menos admitidas como merecían sus servicios, pese a sus clamorosos esfuerzos por obtener el premio de un mañana más estable, más seguro y más sereno, lejos de las cajas de guerra. Debió de ser entonces, o en algún momento entre esta primera jornada a África y la que lo encaminaría después a la corte de Portugal tras su regreso en el mes junio de 1577, cuando Aldana reconocería la vanidad del mundo en uno de los sonetos más bellos y sinceros de cuantos se han escrito en lengua castellana. El sentimiento del poema debió gestarse entre julio y diciembre de 1576 cerca de la presencia de Montano, quien coparticipaba junto a su amigo de la misma aflicción y del mismo desencanto, y en cuyos versos pudo encontrar el discípulo la forma de homenajear y consolar al maestro:

En fin, en fin, tras tanto andar muriendo, tras tanto varïar vida y destino, tras tanto, de uno en otro desatino, pensar todo apretar, nada cogiendo,

tras tanto acá y allá yendo y viniendo, cual sin aliento inútil peregrino, ¡oh Dios!, tras tanto error del buen camino, yo mismo de mi mal ministro siendo,

hallo, en fin, que ser muerto en la memoria del mundo es lo mejor que en él se asconde, pues es la paga dél muerte y olvido,

y en un rincón vivir con la vitoria de sí, puesto el querer tan sólo adonde es premio el mismo Dios de lo servido. ${ }^{179}$

178. El 6 de febrero Aldana ya había salido de España con destino a Berbería. Sobre esta comisión africana véase Rivers (1953: 527-529) y Lara Garrido (1985: 31).

179. Aldana (Poesías castellanas completas, pp. 429-430). Nótese la deuda de las dos primeras estrofas con estos versos de la oda a Pedro Vélez de Guevara: "Testis dolorum maestitiae et grauis / iniuriosis aula frequens malis, / testisque cursus, in remotas / quo feror excutiorque terras", vv. 49-52, en Pozuelo Calero (2011). La idea de ir vagando por la tierra inútil y dañinamente, la certeza de la vanidad de los hombres y el deseo de huir del mundo para hallar el apacible y recóndito rincón de la vida contemplativa respiran en la oda de Montano. 
Es del todo estimulante comprobar el enorme grado de correspondencia existente entre las vicisitudes y circunstancias respectivas de Aldana y Montano. Si el poeta marchó a África inesperadamente, tras una agotadora defensa y reivindicación de su dignidad, sin haber visto recompensados sus veinticuatro ańos de servicios, no menos dramática resultó la fortuna del sabio frexnense tras su regreso a la corte espańola. Como se ha señalado antes, la brutal oposición que León de Castro había sostenido durante años contra la Políglota se oficializó en Espańa con la requisitoria que el 9 de noviembre de 1576 escribió Castro al licenciado Hernando de Vega para que el propio Montano se justificara ante el Tribunal de la Inquisición de las imputaciones dirigidas contra su Biblia. El caso fue encomendado al jesuita Juan de Mariana, quien emitió su veredicto en agosto de 1577. Las conclusiones del padre Mariana, tras un minucioso y objetivo examen de la obra, resolvían que Montano podría haber tenido más "cuidado del que muestra en defender y dar toda auctoridad a nuestra editión de la Vulgata"; y "que se nota que en esta obra [la Políglota] se hallan nombres de herejes y auctores reprobados", como también "se advierten algunas faltas del último tomo del Apparato, y particularmente de aver hecho tanto caso de libros de hebreos y tan poco de lo que los sanctos y otros auctores nuestros [...] han escripto". Por último, el veredicto aseguraba que el rey "no ha ganado mucha honra en averse puesto su real nombre en esta obra, y quanto más fuere, ganará menos, y de aquí a cien años se verá más la falta". ${ }^{180}$ Como toda la crítica montaniana ha deducido, estas conclusiones "debieron suponer un mal trago para Montano"; ${ }^{181}$ con todo, la salomónica resolución del padre Mariana aconsejaba finalmente que la Políglota recibiera la aprobación solicitada, lo cual sirvió al menos para acallar las críticas a la obra por algunos años.

Durante todo el tiempo que sonó este ruido ocasionado por el proceso inquisitorial sobre la Biblia Regia, Montano tuvo que aceptar, además, una decisión totalmente inesperada que vino a derrumbar las escasas esperanzas que aún pudiera depositar en su pretensión de liberarse de los negocios de la corte y de quedar apartado en su anhelada Peña. Que Montano aún mantenía esta esperanza a los cinco meses de haber llegado a la corte de Madrid lo confirman sus propias palabras en carta al humanista Fulvio Orsini: "io penso passar in Andaluzia al fine di questo Febraro proximo col favore di Iddio". ${ }^{182}$ Pero nada más lejos de la realidad para desgracia de Montano. Absolutamente desconcertado y dolorido debió sentirse el teólogo frexnense cuando recibió por parte de Felipe II la comisión más tediosa de cuantas podía imaginar: la catalogación y organización de los fondos de la Biblioteca de San Lorenzo de El Escorial, buena parte

180. Carta de Juan Mariana a Gaspar de Quiroga, 16 de agosto de 1577, en Macías Rosendo (1998: 464-468).

181. Macías Rosendo (2006: 37).

182. Carta de Arias Montano a Fulvio Orsini, 19 de diciembre de 1576, en Domenichini (1988: 572). 
de cuyos volúmenes impresos y manuscritos habían sido adquiridos por el propio Montano a lo largo de sus peregrinaciones; labor, qué duda cabe, muy "poco grata para quien deseaba un merecido retiro dedicado a sus estudios biblistas"183. Como se dice en las memorias de fray Juan de San Jerónimo, Montano se incorporó a su nuevo cargo el 1 de marzo de 1577, para "expurgar y ordenar la librería Real de Sant Lorencio como persona que tiene las partes necesarias para empresa tan principal y de tanta confianza como es esta". ${ }^{184}$ Desde luego, nada podía tener de principal esta empresa para Montano, pues, como confesó a Zayas tan solo tres meses después de asumir sus funciones como bibliotecario, el erudito ansiaba desesperadamente "salir presto de aquí", y admitía con resignación y sin ningún entusiasmo: "Hasta agora no sé lo que el rey quiere de mí, y voy contemporizando y callando hasta acabar este índice que voy haciendo, para pedirle luego la licencia que me ha prometido para ir a ver a mis hermanos y tierra, y espero de concluir en todo junio, si Dios quiere, habiendo yo de hacer asiento en corte o cerca, que es lo que menos deseo". ${ }^{185}$

Tampoco debía de conocer Aldana lo que su rey querría o esperaba de él cuando, poco antes del 10 de junio de 1577, el poeta regresó a España tras haber finalizado su misión de reconocimiento de las marinas y las fortalezas del norte de África, de donde traía "razón muy particular de todo lo que conviene saberse"186 para llevar a cabo las disposiciones y estrategias que exigía la proyectada e insensata expedición que pensaba acaudillar en persona el joven rey don Sebastián. Es de celebrar que la cadena de peripecias que afectaron al poeta inmediatamente después de su regreso a la corte madrileña en 1577 fuera magistralmente reconstruida por Elias L. Rivers a golpe de los numerosos documentos hallados en el Archivo General de Simancas, los cuales, a la luz y el calor del relato que se ha ido trazando en estas páginas, destilan las implicaciones morales y psicológicas en Aldana de una comisión diplomática y de tanta trascendencia para el estado como lo fue su ida a la corte de Portugal para "hazer relaçión al Ser[enísi]mo Rey de lo que vio en la jornada de que húltimam[en]te ha venido". ${ }^{187}$

En efecto, aprovechando que don Sebastián "folgou muito co[m] ser vindo o soldado que foi a Berberia" y que deseaba "ver a rellacáo do que vio e achou e o ouvir", ${ }^{188}$ el duque de Alba, histórico protector del apellido Aldana y, desde

183. Dávila Pérez (2002a: 383).

184. Memorias de fray Juan de San Gerónimo, en CODOIN, tomo VII (1845: 185).

185. Carta de Arias Montano a Gabriel de Zayas, 31 de mayo de 1577, en CODOIN, tomo XLI (1862: 345-346).

186. "Relación q[ue] se dio aquí a Luys de Silva y se embió a don Juan de Silva, en XI de junio de 1577", en Archivo General de Simancas, Estado, leg. 394, ff. 57 y 66; véase también Rivers (1953: 529).

187. Carta del duque de Alba a Gabriel de Zayas, 21 de junio de 1577, en Archivo General de Simancas, Estado, leg. 394, f. 65; véase también Rivers (1953: 530).

188. Respuesta del rey portugués a los puntos de la relación que le hizo Cristóbal de Moura de parte de Felipe II (sin fecha), en Archivo General de Simancas, Estado, leg. 394, f. 256. 
1567, concretamente de Francisco, convenció a Felipe II para que el poeta fuese a dar cuenta ante el mismísimo rey de Portugal de la información que había recabado durante su incursión africana, "teniendo por cierto que por ella desistiría de la empresa, o no iría en persona a ella". ${ }^{189}$ El 23 de junio, escribía Felipe II a su embajador en Portugal Juan de Silva:

Este es el capitán Fran[cis]co de Aldana, tan buen soldado y tan cuerdo que ha traýdo muy buena relación de lo que llevó a cargo y assí he mandado que vaya agora con este despacho, para que él la haga de todo ello al rey, mi sobrino, al t [iem] po y de la manera q[ue] vos lo concertáredes y se lo advirtiéredes y ordenáredes, a fin que se proceda en el neg[oci]o con el peso y consideración que la qualidad dél lo requiere; y cumplido que haya con esto le bolveréys a despachar con brevedad, bien informado de todo lo que viéredes que conviene que acá se sepa. ${ }^{190}$

Fue un viaje rápido, como lo fue también el devenir insospechado de los acontecimientos. Salió Aldana de Madrid el 26 de junio y el día 30 hacía ya su entrada en Lisboa. En la corte madrileña el éxito de la embajada se daba por seguro, pero cuando el poeta escribió a Gabriel de Zayas el 10 de julio desde Portugal un primer informe de sus encuentros con el sobrino de Felipe II, había ocurrido ya "un giro espectacular" 191 y prácticamente definitivo: Aldana, aun haciéndole "l'impresa più difficultosa di quello che ei la stimava" ${ }^{192}$ no solo se vio altamente valorado, halagado y apreciado por una majestad como el rey de Portugal, unido por "natura propia" al Rey Católico, sino que también conectó, desde su obsesión por el peligro turco y por el de los enemigos de Dios, con la idea de cruzada que aquel tan obcecadamente sostenía. Además, habiendo sido informado seguramente antes por el embajador, Aldana no podía desconocer que don Sebastián "consideraba lo más prudentes avisos meros disfraces de cobardía", 193 acusación que no podía permitirse de ningún modo quien había tenido que defender y aun demostrar en la corte por medio de relaciones ajenas

189. Cabrera de Córdoba (1876, II: 395). El papel fundamental del duque de Alba en la decisión de enviar a Aldana a la corte portuguesa está fuera de toda duda: la elección del hispanoflorentino fue, a todas luces, una apuesta personal de Alba, a juzgar por sus esfuerzos casi paternalista a la hora de procurar que se le diese a Aldana la ayuda de costa necesaria para el viaje, "que a de ser para yda y buelta, y que no aya de gastar de su hazienda", carta del duque de Alba a Gabriel de Zayas, 21 de junio de 1577, en Archivo General de Simancas, Estado, leg. 394, f. 65. Y en otra firmada a las tres de la mañana de la noche de San Juan, el Duque insiste: "q[ue] se dé luego a Aldana [...] los doçientos $\mathrm{d}$ [ucado]s para el viaje; me pareçe que los avrá bien menester, aviendo de yr y bolver", en Archivo General de Simancas, Estado, leg. 394, f. 75; véase también Rivers (1953: 530-531).

190. Carta de Felipe II a Juan de Silva, 23 de junio de 1577, en Archivo General de Simancas, Estado, leg. 394, f. 260.

191. Lara Garrido (1985: 32).

192. Conestaggio (1585: 17v).

193. Queiroz Velloso (1943: 151). 
su honor, su valor y la justicia que merecía una trayectoria de veinticuatro ańos de servicios. Por todo ello, Aldana remitió a Zayas el siguiente escrito, tan contrario a las actitudes escépticas de Juan de Silva, el duque de Alba o Felipe II:

[...] a esta ora tengo hablado tres vezes a su Mag[esta]d, el qual me tiene lleno de amor y admiratión, porq[ue] jamás creý ver en tan pocos años tanto entendim[ient] o y destreza en las preguntas q[ue] me ha hecho sobre mi comisión, discurriendo por ellas tan soldadescamente q[ue] a sido menester abrir los ojos y las orejas para entendelle y respondelle. Guárdele Dios y proportione su poder a su valor, q[ue] es el q[ue] tiene menester la soldadesca cristiana para levantarse del abismo a do va cayendo. ${ }^{194}$

Es indiscutible que el amor y la admiración entre Aldana y don Sebastián fueron recíprocos. El 12 de julio, Juan de Silva escribía a Zayas:

[...] vino el capitán Aldana, avissé luego al rey y embióle a llamar el día siguiente al monest[eri]o de Belem, donde se hallava. Oyóle gran rato y examinóle muy particularm[en]te con el diseńo delante; dióle Aldana tan buena razón de todo como quien también reconoçido traýa aquel sitio y las demás particularidades q[ue] se devían advertir. Quedó el rey muy contento; no le ha despachado porque le quiere oyr otra vez. ${ }^{195}$

El rey portugués oyó de nuevo al hispanoflorentino en un Consejo de Guerra reunido en Sintra antes del 30 de julio. Ese día, sellada ya la alianza personal que tan fatídica habría de ser para el poeta, el propio don Sebastián redactaba de su puño y letra este entusiasmado testimonio de su aprecio y consideración por el capitán Aldana, dirigido a Felipe II:

Tendo ouvido o Capitáo Francisco de Aldana e entendendo particularmente, polo que me referio e do que pude colegir e infirir, quáo inteiramente cumprio com as obriguaçôes do a que foi e quão particularmente vio e reconheçeo tudo o que cumpria, e entende e alcançou o que daquelas partes tão divisas e fracas convem, me pareçeo escrever a Vossa Magestade quão bem me pareçeo ço que fez: é tanto em favor da empresa tudo o que vio, conforme tãobem a o que se tinha visto. E, por o que dele entendi, me pareçeo dino de onrra e merce, e toda que lhe Vossa Mgestade fizer sera para mim mui grande. ${ }^{196}$

194. Carta de Francisco de Aldana a Gabriel de Zayas, 10 de julio de 1577, en Archivo General de Simancas, Estado, leg. 394, f. 253; citada también en Rivers (1953: 532-533, y 1957: L-LII). 195. Carta de Juan de Silva a Gabriel de Zayas, 12 de julio de 1577, en Archivo General de Simancas, Estado, leg. 394, f. 84; véase también en Rivers (1953: 534-535).

196. Carta de don Sebastián a Felipe II, 30 de julio de 1577, en Archivo General de Simancas, Estado, leg. 394, f. 89; se sigue la transcripción de Rivers (1953: 535-536). En el folio siguiente se encuentra una copia en castellano de esta carta, que Rivers no vio, como bien advirtió Ruiz Silva (1981: 29). 
Cuando, el 6 de agosto, Aldana obtuvo la licencia para volver a Castilla, la compulsiva fascinación de don Sebastián por el talante del poeta era ya ilimitada. Así se lo expresó el embajador de Felipe II en Portugal al secretario Zayas el mismo día de su partida: "Oy mandó [el rey] despachar al cap[itá]n Aldana y le embió mil ducados, aviéndole hecho mill favores que estima el cap[itá]n más que la $\mathrm{m}[\mathrm{e}] \mathrm{r}[\mathrm{ce}] \mathrm{d}$, aunque también a sido honrada. A mi parecer, es lo él tanto q[ue] mereçe que se las haga Su M[ajesta]d muy cumplidas" ${ }^{197}$ Por supuesto, Silva también dio parte de ello a Felipe II por deseo expreso de su sobrino:

El capitán Francisco de Aldana a servido a V[uestra] M[ajesta]d muy açertadamente en cumplimiento de lo que allá se le mandó y aquí se le a advertido. Queda el rey con gran satisfaçión de su persona y entendim[ient]o, y assí me lo a mandado significar a V[uestra] M[ajesta]d; y sin dubda tiene muy buenas partes para servir a V[uestra] M[ajesta]d la m[e]r[ce]d que por sus serviçios a mereçido. ${ }^{198}$

Aldana regresó a Madrid poco antes del 17 de agosto, fecha en la que entregó en mano a Felipe II la carta que don Sebastián había escrito en su favor, como se advierte en la nota secretarial de la cubierta de dicha carta: "con el cap[it]án Fran[cis]co de Aldana, q[ue] se la dio a 17 de agosto". 17 de agosto. Es ineludible advertir que, en tan solo dos meses, el poeta había logrado, ni más ni menos que por parte de un rey, el reconocimiento que su honor maltrecho reclamaba. Aldana, recuérdese, había sido herido de gravedad en Flandes y había perdido allí un hermano; había tenido que lidiar, poco después, con sus camaradas amotinados, debiendo persuadirles y convencerles de que depusieran su actitud deshonrosa; había sido ninguneado por la gran casa florentina, aun habiéndose formado en ella desde sus primeros años y vivido no con otro nombre que el de criado mediceo; cargaba también con el agravio de ver su carrera estancada por un odio personal, el mismo que habría alargado sus días de desamparo y miseria en los Países Bajos. Aldana, recuérdese, tras veinticuatro años de servicio continuado, había resuelto irse a España a dar cuenta de todas sus desgracias a Felipe II, para reivindicarse y reparar ante su real figura la destrucción de su persona. Y pese a todo, Aldana todavía tuvo que aguardar lo que dispusiera la clemencia del rey sobre su justicia, postrado por largos meses, sin norte, en la corte madrileña. Ese estado de decaimiento y degradación, que llevaría al poeta a proyectar el 7 de septiembre su programa de retiro contemplativo junto a Montano, tan decaído y degradado como él, no podía sino remontar y revertirse eufórico ante las muestras de consideración que le habían dispensado en Lisboa, resultando ser cuanto tenía y cuanto se le había ofrecido a modo de esperanza.

197. Carta de Juan de Silva a Gabriel de Zayas, 6 de agosto de 1577, en Archivo General de Simancas, Estado, leg. 394, f. 113; véase también en Rivers (1953: 535).

198. Carta de Juan de Silva a Felipe II, 6 de agosto de 1577, en Archivo General de Simancas, Estado, leg. 394, f. 107. 
Así, animado seguramente por las recientes recomendaciones de don Sebastián y secundado por el inestimable apoyo del duque de Alba, hacia el 14 de septiembre Aldana se sintió lo suficientemente respaldado y legitimado como para escribir un memorial a Felipe II. Era el momento de volcarse en la relación de sus trabajos y servicios y de solicitar oficialmente su justa pretensión: la Mota de San Sebastián. He aquí, otra vez, el conocido documento, redactado tan solo unos días después de que Aldana concluyera su Carta para Arias Montano:

Francisco de Aldana, capitán q[ue] ha sido de infantería española en Italia y Flandes, por V[uestra] Mag[esta]d Sargento mayor en la segunda jornada q[ue] hizo el $s[$ eñ] or don Juan en Levante, y diversas vezes en Olanda, governador de compañías assí españolas como valonas y alemanas, con cargo de la Artillería de V[uestra] Mag[esta]d en batterías q[ue] allá se ofrecieron, dize q[ue], aviendo servido a V[uestra] Mag[esta]d veynte y quatro ańos, assí de soldado aventajado como de los referidos cargos, y agora últimamente, después de aver estado diez meses en $\mathrm{Ma}-$ drid, en las dos jornadas q[ue] V[uestra] Mag[esta]d le mandó hazer fuera de sus reynos, donde de su parte no ha podido obrar con más fidelidad y diligentia de lo q[ue] ha hecho, añadiéndose a estos méritos los de sus antepassados, la muerte de un hermano en Olanda y el quedar su persona con menos sangre de la derramada sirviendo a V[uestra] Mag[esta]d, le suplica sea servido hazelle merced de la Mota de San Sebastián, para q[ue] le sirva en ella, no con fin de retirarse de las ocasiones, más para tener lugar de donde salga a ellas, empleando los años q[ue] le quedan de vida como los passados en servicio de su rey y señor, porque hasta agora no le ha hecho V[uestra] Mag[esta]d merced en que estrive para merecer otras mayores, esperadas como de hombre benemérito de su real grandeza. ${ }^{199}$

En su intento por reconstruir las marañas burocráticas de este memorial, Rivers afirmó que llegó primero a manos del secretario Mateo Vázquez, quien se lo mandó luego a Juan Delgado, del Consejo de Guerra, con la recomendación de que se aprobara. Como bien advirtió el crítico norteamericano, diez días después Delgado se lo devolvió a Vázquez, diciendo que lo había considerado el Consejo y que este había decidido hacerlo mandar al rey, quien tenía la consulta, o sea, la lista de otros candidatos para el puesto. En dicha lista, que contenía los nombres de diecinueve aspirantes a la tenencia del castillo de San Sebastián y un sumario de sus cualidades y hojas de servicio, no se añadió el nombre de Aldana, pero el 12 de noviembre de 1577 se tomó por fin la decisión a su favor, garabateando Vázquez en el dorso de la consulta: "Al capitán Francisco de Aldana”. Lo que Rivers no se preguntó ni podía saber es por qué el nombre de Aldana aventajó al de los diecinueve candidatos (capitanes en su mayor parte) que solicitaron también la concesión de dicha tenencia. Hoy la respuesta no puede

199. Memorial de Francisco de Aldana a Felipe II, c. 14 de septiembre de 1577, en Archivo General de Simancas, Guerra y Marina, leg. 82, f. 156; véase, acompañado de facsimilar, en Rivers (1953: 550-551), Ruiz Silva (1981: 23-25) o Lara Garrido (1985: 35). 
ser más incontestable: por la influencia directa del duque de Alba. Fue al Gran Duque a quien Aldana entregó su memorial, escrito días antes del 15 de septiembre, como puede comprobarse por esta carta inédita que envió Alba a Mateo Vázquez el día 14:

Con esta embío a V[uestra] M[erced] una petición del cap[itá]n Aldana, que por darme aý tanta priessa mi indispusiçión no pude darla a Su M[ajesta]d. Me la hará de presentársela en mi nombre y hazer por su pretensión al d[ich]o capitán la m[e] r[ce]d q[ue] sus servi[çi]os mereçen, que yo desseo tanto su acrecentamento q[ue] porné a mi qüenta la que V[uestra] M[erced] le hiziere. ${ }^{200}$

Y por supuesto que obtuvo su acrecentamiento. El 19 de noviembre exactamente, Aldana vio ganada su justicia con la provisión que le concedía el título de alcaide del castillo de San Sebastián; ${ }^{201}$ pero una nueva orden del rey impediría que tomara la posesión de la tenencia de la fortaleza guipuzcoana. De hecho, jamás la tomaría, aunque el recién nombrado castellano no pudiera imaginarlo. ${ }^{202} \mathrm{El} 7$ de diciembre, estando todavía en Madrid, el poeta recibió un encargo especial y de considerable relevancia por parte de Felipe II: escoltar, desde Alcalá de Henares hasta el castillo de Arévalo, al conde de Bura, Felipe Guillermo, hijo de Guillermo de Orange, a quien Felipe II tenía como rehén en España desde $1568 .{ }^{203}$ No obstante, la orden del rey, además de dictar la custodia del conde de Bura en el camino de Alcalá a la villa de Arévalo, también mandaba que le "tomase en prisión y guarda" y que "asist[iera] con él" en el castillo arevalense, motivo por el cual Aldana "no a podido ni puede yr a tomar la posesión

200. Carta del duque de Alba a Mateo Vázquez, 14 de septiembre de 1577, en Instituto de Valencia de Don Juan, envío 6, tomo 1, doc. 105. Por tanto, la fecha de 15 de septiembre que figura en el dorso del memorial debe ser por fuerza la del día en que llegó a las manos del secretario, y no la del documento mismo, que va sin fechar.

201. Véase el documento -inédito- de concesión del "Título de alcayde del castillo y mota de San Sevastián al Cap[it]án Fran[cis]co de Aldana”, a 19 de noviembre de 1577, en Archivo General de Simancas, Guerra y Marina, leg. 174, f. 90.

202. Aldana permaneció en Arévalo hasta el día de su partida a Madrid, para inmediatamente después dirigirse a la trágica jornada de África. Léase este documento inédito: "Sepan quantos esta carta de poder vieren como yo, Fran[cis]co de Aldana, castellano del castillo y mota de San Sebastián por su M[a]g[esta]d, q[ue] es en la provinçia de Guipozcoa, digo que por quanto por mandado de su M[a]gesta[d] voy a servir al rey de Portugal en la jornada q[ue] haze en África, a cuya causa yo no puedo yr a tomar e continuar la possesión de la dicha tenençia por estar de partida para la dicha jornada ni asistir en ella como soy obligado y hazer lo que devo conforme al título de su M[a]g[esta]d q[ue] de la dicha tenençia me dio...”, carta de poder de Francisco de Aldana, en Madrid, a 8 de julio de 1578, en Archivo General de Simancas, Contaduría del Sueldo, 376, vol. 1 , s. f.

203. Véase la "Minuta de las cédulas q[ue] llevó el capitán Fran[is]co de Aldana, de Madrid a VII de Dezi[embr]e 1577, pa[ra] lo del conde de Bura", en Archivo General de Simancas, Estado, leg. 159, f. 70r; véase también Rivers (1953: 552). 
de la d[ich]a tenençia [del castillo de San Sebastián]" ${ }^{204}$ Aunque el poeta no pudiese desempeñar, de momento, el cargo de castellano por el que tanto había pugnado, es indudable que la obtención del título debió aliviar sobremanera sus ánimos y contribuir a que acatará orgullosa y disciplinadamente la nueva tarea que Felipe II le había encomendado. Custodiar al hijo del líder de la rebelión flamenca era, a ojos de todo el mundo, un encargo importante, que denotaba la confianza que ahora depositaba el rey en ese sagaz consejero, informador, diplomático, alcaide y, ante todo, experto militar que era Aldana. Así, sabiéndose dignificado no solo por el duque de Alba o el rey don Sebastián, sino también por Felipe II, Aldana informó solícitamente al rey el 28 de diciembre del cumplimiento de las órdenes reales con relación a las últimas disposiciones para la guarda del conde de Bura. Por ser desconocida y útil para entender la extrañeza que un mes después mostrará Montano al conocer las nuevas circunstancias de su amigo, se reproduce aquí por entero la carta que el poeta envió a Felipe II desde su puesto en Arévalo:

La orden q[ue] la carta de V[uestra] M[ajesta]d me dio sobre trocar algún número de los soldados q[ue] vinieron en guarda del conde de Bura con otros deste pueblo para hazer más seguridad y menos gasto en lo concerniente a su real servicio luego puse en execución, disponiéndola (sigún el alvedrío q[ue] V[uestra] M[ajestad] me dexava) en la siguyente forma: escogí de los treynta soldados una esquadra de a diez con su cabo por los menos reboltosos y demás cuydado entre ellos; hize q[ue] quedasen otros dos cabos, hombres pláticos y de servi[ci]o para el gobierno de las otras dos esquadras q[ue] salen deste pueblo, porq[ue] sin ellos no acertarán con la vigilancia q[ue] les tocca tener al ministerio q[ue] se prosigue, de manera q[ue] vengo a quedar, con un ayudante o sargento desta gente, con tres cabos soldados viejos, uno para los diez escogidos y dos para los veynte mudados. Al dicho ayudante, cabos y diez daré la paga ordinaria q[ue] se señaló en Madrid, por no quedarles otro abrigo q[ue] su sueldo, y a los del pueblo señalaré a veynte reales por hombre, en consideración del suplimento q[ue] les haze su acomodada y ordinaria bivienda; aunque estoy dudoso si lo aceptarán, por la comparación q[ue] resulta de los unos a los otros. Esta es la orden q[ue] he tenido en obrar el mandam[ien] to de V[uestra] M[ajestad], la qual se siguyrá hasta q[ue] me viniere otra de su real mano, cuya S[acra] C[atólica] R[eal] persona guarde N[uestro] S[eñor] como la cristiandad ha menester. ${ }^{205}$

El 28 de diciembre de 1577 parece que la actitud vital de Aldana distaba mucho de aquella voz melancólica que declarara el 7 de septiembre su determinación de romper "a la esperanza lisonjera / el lazo en que me asió con

204. Cédula inédita del rey sobre el salario y la provisión de Francisco de Aldana, alcaide del castillo y mota de San Sebastián, ante su nuevo encargo en Arévalo, en Archivo General de Simancas, Contaduría del Sueldo, 376, vol. 1, s. f.

205. Carta de Francisco de Aldana a Felipe II, 28 de diciembre de 1577, en Archivo General de Simancas, Estado, leg. 159, f. 137. 
doble trato". Aldana, cuya voz íntima y afligida ansió "torcer de la común carrera / que sigue el vulgo y caminar derecho / jornada de mi patria verdadera", ${ }^{206}$ había seguido cortes y servido a reyes hasta encontrar finalmente el premio no en "la verdadera patria que para siempre ha de durar", como dijo alguna vez su maestro, ${ }^{207}$ sino en aquella misma vida temporal que tanto lo había maltratado. Pese a que conservó siempre su ímpetu guerrero, esencial constitutivo de su personalidad, es muy posible que en sus momentos de mayor desesperanza Aldana llegara a planear su abandono de las armas para abrazar una vocación religiosa, en el caso, al menos, de que no conseguiera vestir el hábito "de más siguridad" que le ofrecería la merced de una alcaidía. No hay duda de que esos, sus más hondos deseos, el poeta debió compartirlos con Montano. La epístola en verso dirigida al frexnense es probablemente la mejor prueba de ello, pero también lo son sin duda las palabras que el propio biblista escribió a Aldana cuando, llegado a Madrid tras diez meses de obligado "destierro" escurialense, ${ }^{208}$ tropezó con la ausencia de su amigo y supo que el proyecto de retiro compartido habría de languidecer ante la nueva dimensión militar y política que había alcanzado Aldana. Con su habitual terneza, dejó escrito Montano:

Grandísima fue la soledad, tristeza y estrańeza q[ue] sentí qua[n]do, venido a esta corte, no hallé a v[uestra] $\mathrm{m}$ [erced], a quie[n] venía a buscar, para despacio co[m] municarle aq[ue]llo q[ue] más e[n]tie[n]do me podría dar co[n]tento e[n] esta vida. Allegóse a la ausentia de v[uestra] $\mathrm{m}$ [erced] el saber q[ue] estava aý occupado por muchos días, y pre[n]dado ya de provisiones y títulos para seguir cortes y servir a los reyes de la tierra y trattar en materias de guerra y otras cosas agenas de lo q[ue] algún día se co[n]fería. Todo lo e[n]derece N[uest] ro S[eño]r para su servi[ci] o. ${ }^{209}$

El lamento y el asombro de Montano pudieran sugerir que Aldana sopesó seriamente con su maestro y padre espiritual las posibilidades de acogerse a una vida religiosa y privada, vuelta hacia ese rincón donde "vivir con la vitoria / de sí, puesto el querer tan solo adonde / es premio el mismo Dios de lo servido". ${ }^{210}$ No parece tener otro sentido "lo que algún día se confería”, esto es, "tratar algún negocio examinando las razones que hay en pro y en contra", ${ }^{211}$ un negocio que,

206. Carta para Arias Montano, vv. 44-48, en Aldana (Poesías castellanas completas, p. 439).

207. Carta de Arias Montano a Gabriel de Zayas, 18 de abril de 1574, en CODOIN, tomo XLI (1862: 305).

208. En carta a Zayas escrita desde El Escorial a 10 de noviembre de 1577, Montano dice: "Mucho sentiría la ida de la corte de aquí si me faltase el consuelo de las cartas de v. m. en este destierro; por tanto le suplico me socorra con ellas mientras aquí estuviere, que yo procuraré acortar el tiempo cuanto me sea posible", en CODOIN, tomo XLI (1862: 352).

209. Carta de Arias Montano a Francisco de Aldana, 30 de enero de 1578, en Biblioteca del campus Barri Vell de la Universitat de Girona, Ms. Aldana, s. f.

210. Aldana (Poesías castellanas completas, p. 430).

211. Covarrubias (1611: 232). 
a buen seguro, debía ser diametralmente distinto y sobre todo ajeno al seguimiento de cortes y al servicio de reyes y opuesto también, cómo no, a "las materias de guerra". Como se ha ido viendo a lo largo de estas páginas, tanto Aldana como Montano habían sucumbido en el teatro del poder de su tiempo, pero en su amistad y conversación hallaron, proyectaron y trazaron el consuelo de su igual condena en "el infierno del común trafago". Era inevitable, pues, que grandísima fuera la soledad, tristeza y extrańeza que sintió Montano cuando certificó las limitaciones que su propio amigo, con pesarosa resignación, ya le había confesado a través de sus versos:
Mas jay de mí!, que voy hacia el profundo do no se entiende suelo ni ribera, y si no vuelvo atrás, me anego y hundo.
No más allá; ni puedo, aunque lo quiera.
Do la vista alcanzó, llegó la mano;
ya se cierra a entrambos la carrera. ${ }^{212}$

Ante las nuevas ocupaciones, recompensas materiales y aspiraciones de quien prometiera al rey don Sebastián "che al tempo venirebbe a servirlo", ${ }^{213}$ solo quedaba, en efecto, esperar a que Dios lo enderezara todo para su servicio. El pesimismo que subyace a las palabras de Montano tenía, en fin, su razón de ser, como tristemente confirmaría el sabio un año más tarde al recibir la noticia de la muerte de Aldana en aquella infausta jornada para la cual Montano no halló nunca ningún fundamento: ${ }^{214}$ "Grande pena me ha dado la muerte del capitán Aldana, y no me la ha aliviado el tener casi pasado este trago con la sospecha grande que dello tenía. Siempre alabado sea Dios, que ansí nos ha castigado por esta parte de Portugal, y nosotros no sé cómo lo sentimos". ${ }^{215}$

Había cerrado Aldana su epístola a Montano expresando su deseo de vivir con el maestro, "en paz dichosa, esto que queda / por consumir de vida fugitiva”, pero era este, desde luego, un anhelo imposible, o dificilísimo, para aquellos que estuvieron obligados a supeditar, siempre, sus esperanzas de soledad contemplativa al servicio y arbitrio de los reyes de la tierra.

212. Carta para Arias Montano, vv. 277-282, en Aldana (Poesías castellanas completas, pp. 450-451). 213. Conestaggio $(1585: 17 \mathrm{v})$.

214. Desde Lisboa, adonde Montano se dirigió poco después de escribir a Aldana, escribió el frexnense en carta a Zayas, a último de febrero de 1578: "Hallo aquí al pueblo descontento con este propósito tan constante que el Rey tiene de hacer jornada para la cual no se halla fundamento", en González Carvajal (1832: 176), doc. n. 62.

215. Carta de Arias Montano a Gabriel de Zayas, 4 de enero de 1579, en CODOIN, tomo XLI (1862: 377). 


\section{Últimos apuntes en torno a la carta de Arias Montano (a modo de epílogo)}

Como tal vez se haya observado ya, la carta que Arias Montano dejó escrita a Aldana en Madrid a 30 de enero de 1578 constituye un testimonio que silencia e insinúa mucho más de lo que expresa, y no por ello deja de ser una fuente de información preciadísima sobre los profundos lazos de amistad que unían a los corresponsales. Antes al contrario: la reserva y secreto celosamente contenidos incluso en la privacidad de la carta traslucen el privilegio de la confidencia que Aldana y Montano se concedieron por medio del vínculo de su consolidada amicitia. Afortunadamente, ni la brevedad, ni la cautela ni el escamoteo a los que Montano somete su comunicación, sin duda comprometedora, impiden a los estudiosos del poeta hispanoitaliano y del sabio frexnense conjeturar acerca de lo omitido o conocer nuevos datos sobre estos dos seres de tan alto y raro vuelo. Arriba se han señalado y valorado ya las alusiones de Montano vertidas en el primer párrafo de la carta, esa evocación a las conversaciones que mantuvo con su amigo y que bien pudieron versar sobre las esperanzas que abrigaría Aldana de materializar al fin su vocación religiosa. Ahora, llegados a este punto, conviene comentar aunque sea muy someramente los demás asuntos referidos en el testimonio, y, por supuesto, el delicioso post scriptum. Seguía Montano en su carta para Aldana:

Vine aquí de S[ant] Lore[n]ço los postreros días de navidad co[n] lic[enci]a q[ue] Su Mag[esta]d me havía promettido para yr a ver mi choçuela e[n] la Peńa, y co[n] ocupaciones de corte y dilaciones de mi amo he perdido todo este mes, e[n] fin del qual me ha dado lic[enci]a co[n] encom[m]ienda q[ue] torne presto, de q[ue] doy a v[uestra] $\mathrm{m}$ [erced] aviso, y le supp[li]co pida a Dios e[n]derece mi camino para servi[ci]o suyo y me ma[n]de si e[n] alguna cosa le puedo dar gusto e[n] este viage o donde estuviere.

Aquel $\mathrm{a}<\mathrm{m}>$ igo y servidor de $\mathrm{v}$ [uestra] $\mathrm{m}$ [erced] $\mathrm{q}[\mathrm{ue}]$ los días pasados le co[m] municó sus buenos de<seos> tiene propósito de effettuarlos abrié[n]dole Dios puerta para ellos, y ha me dado ca<rgo> de q[ue] dé esto a e[n]tender a v[uestra] $\mathrm{m}$ [erced] y le affirme $\mathrm{q}[\mathrm{ue}]$ en ninguna pers[on] a d'este $\mathrm{mu}[\mathrm{n}$ ] do tien $<$ e con>fiança $\mathrm{q}$ [ue] le sabrá procurar y adereçar su co[m]modidad sino es a v[uestra] $\mathrm{m}$ [erced], y $\mathrm{q}[\mathrm{ue}] \mathrm{co}[\mathrm{n}] \mathrm{g}<\mathrm{ran}>$ certeza parte muy assigurado a buscar aq[ue]l thesoro y co[n] cluir su casamiento co $<\mathrm{n}$ per $>$ sona q[ue] tanto ama y deve amar, y rogóme q[ue] enco[m]me $<\mathrm{n}>$ dasse a v[uestra] $\mathrm{m}$ [erced] el secreto, por recelo de los adversarios y co[m]petidores, y ansí lo e[n]comie[n]do de su parte y de la mía. Ha me dexado una carta para v[uestra] $\mathrm{m}$ [erced], la qual yo no he querido fiar de los $\mathrm{ca}<\mathrm{minos}>\mathrm{y}$ tiempos, y queda aquí e[n]co[m]me[n]dada a un amigo fiel q[ue] sin saber cosa d'esto la ten<drá> guardada hasta q[ue] v[uestra] $\mathrm{m}$ [erced] venga y se la dará e[n] mano propria, remittié[n]dose e[n] la ex*** a lo q[ue] por tie[m]po succediere y al buen juicio e industria de v[uestra] $\mathrm{m}$ [erced].

El segundo párrafo de la carta no destaca en apariencia por su alto nivel informativo, pero es de notar que contribuye decisivamente a aclarar algunos 
puntos, menores y no tan menores, de su biografía. Una cuestión que podría considerarse menor, aunque indispensable para fijar los pasos de Montano, es su estancia, hasta ahora desconocida, de un mes entero en la corte de Madrid en enero de 1578, dato que corrige la creencia de que el biblista estuvo en El Escorial hasta finales de dicho mes. No fue así, como él mismo le comunicó al poeta, pues partió de San Lorenzo en "los postreros días de navidad", es decir, a principios de enero.

De ninguna manera puede considerarse superflua la información relativa a la ida de Montano a su queridísima Peńa. Cualquiera que se haya acercado a la biografía del frexnense sabe que, antes de llegar a Andalucía hacia el mes de marzo, Montano pasó por Lisboa, adonde llegó el 20 de febrero y donde estuvo poco más de una semana. De hecho, las cédulas de guía y paso que Felipe II expidió a Montano para que pudiese viajar cómodamente y sin que los aduaneros entorpecieran su camino de Madrid a Lisboa llevaban fecha de 29 de enero de 1578, es decir, se emitieron justo un día antes de que Montano se dirigiera a su amigo. ${ }^{216}$ Es más, al día siguiente de que Montano escribiera a Aldana, Felipe II despachó una carta a su embajador en Portugal para advertirle del inminente desplazamiento de su capellán hacia aquellos dominios: "Daraos esta el Doctor Arias Montano [...] que va a ese Reyno con mi sabiduría y licencia a lo que de él entenderéis". ${ }^{217}$ La cuestión aquí es: ¿por qué Montano no informó al poeta de su ida a Portugal? Puesto que la crítica montaniana ha sostenido, "con mayor imaginación que conocimiento", ${ }^{218}$ que el viaje del biblista a Lisboa era en verdad una misión política encubierta, podría pensarse que Montano ocultó a Aldana su comisión secreta con supuestos fines políticos, como "explorar qué respaldo popular tendría el posible derecho dinástico de Felipe II al trono portugués", ${ }^{219}$ o incluso "preparar la campańa política del rey", convirtiéndose "en lo que hoy llamaríamos un espía". ${ }^{220}$ No obstante, gracias a un espléndido trabajo de Manuel José de Lara Ródenas, hace ya varios años que quedó demostrado (y con sólidos argumentos, además) que el paso de Montano por Lisboa no tuvo ningún sentido político ni diplomático. Lo que de verdad llevó a Montano a la capital portuguesa, aparte de su deseo de visitar a compañeros y amigos y de su disposición para mediar en el problema de los mercaderes castellanos (a quienes se les había incluido en la lista de conversos portugueses obligados a contribuir a la Corona), ${ }^{221}$ fue una campaña científica de recopilación de con-

216. Véase González Carvajal (1832: 173-174), doc. n. 59 y doc. n. 60.

217. Carta de Felipe II a Juan de Silva, 31 de enero de 1578, en González Carvajal (1832: 173), doc. n. 58.

218. Lara Ródenas (1998: 343).

219. Sánchez Rodríguez (1997: 113).

220. Alvar Ezquerra (1998: 191 y 207).

221. Aprovecho la nota para dar noticia de una carta desconocida de Arias Montano a Zayas sobre este tema, del 24 de septiembre de 1577, en Archivo General de Simancas, Estado, leg. 394, f. 287. 
chas marinas, una afición bien conocida tanto por los estudiosos del humanista como por los de Aldana, quien pintó en los inolvidables tercetos de su epístola a Montano un paisaje tentador de luz, orillas y arenas repletas de conchas de caracoles para complacer a su amigo. ¿No sería acaso esta oportunidad científica de Montano en Portugal y su vuelta a la Peña -su verdadero destino- lo que "más entiendo me podría dar contento en esta vida" y lo que "despacio" querría "co[m]municarle" a su gran amigo, "a quie[n] venía a buscar"? Probablemente, mas no era este el motivo de la carta.

El motivo principal de la carta de Montano a Aldana se encuentra, sin duda, velado en el último párrafo del escrito. Montano, en calidad de agente informador, avisa al poeta de que un amigo suyo ha decidido concluir secretamente su casamiento, "co<n per $>$ sona q[ue] tanto ama y deve amar". Lamentablemente para el investigador de hoy, la enorme discreción de Montano impide descubrir y defender a ciencia cierta la identidad de dicho amigo. Ahora bien, ¿no resultaría irresistible traer a un personaje íntimamente relacionado con Aldana que llegó a casarse en secreto en 1578? Sin duda. ¿Y acaso no sería más irresistible todavía traer el nombre de dicho personaje si este hubiese escrito a Aldana justo en el año anterior? Evidentemente. Pues bien, tráigase entonces a don Fadrique de Toledo, quien, según se deduce de la documentación relativa a un caso que escandalizó a toda la corte y que supuso el destierro y el declive de los Alba, hacia octubre de 1578 quebrantó su confinamiento en Tordesillas para casarse en secreto con su prima María de Toledo. ${ }^{222}$ La profunda amistad que existió entre don Fadrique y Aldana puede comprobarse en la carta citada anteriormente que escribió el hijo del duque de Alba para mostrar su apoyo al poeta. Pero para encajar a don Fadrique en la identidad de ese amigo y "servidor" que refiere Montano, parece totalmente necesario conectar al pretendiente con el sabio de Fregenal, para lo cual es insuficiente y no aporta demasiado el hecho de que ambos se conocieran y trataran en los Países Bajos. Sí pudiera arrojar un poco de luz, en cambio (quizá no ahora, pero sí en futuras investigaciones), un par de referencias llamativas entresacadas del epistolario de Montano. La primera se encuentra en una carta del biblista dirigida al secretario Mateo Vázquez del mes de octubre de 1577. En el pie de dicha carta, cuyo asunto es por completo ajeno al tema en cuestión, se halla una anotación de mano de Felipe II en la que puede leerse lo siguiente: "También hablaremos oy en esto. Y traed lo de don Fadrique de Toledo, que procuren de llamaros temprano". ${ }^{223}$ De este escueto apunte podría deducirse que Felipe II consideró el polémico caso de don Fadrique con

222. Obedeciendo así las órdenes de su padre y rompiendo todo posible compromiso con Magdalena de Guzmán, a quien había prometido matrimonio en 1566. Para todos los antecedentes, detalles y consecuencias del caso, se remite al excelente trabajo de Martínez Hernádez (2013).

223. En carta de Arias Montano a Mateo Vázquez, octubre de 1577, en Macías Rosendo (2008: 309-310). 
Montano, una idea que no carece en absoluto de sentido si se tiene en cuenta que el frexnense conocía y había tratado personalmente al hijo de Alba en su época de Flandes, como se ha dicho. Por otra parte, este posible nexo entre Montano y el problema de don Fadrique pudiera verse reforzado por unas palabras, cuidadosamente escogidas y empleadas, que Montano dirigió a Zayas en apoyo del Gran Duque en junio de 1578, justo cuando las relaciones entre los Toledo y la Corona estaban alcanzando su más alto grado de deterioro a causa del proceso contra el futuro IV duque de Alba:

Gran pena me ha dado lo que v. m. me ha escrito de la indisposición del duque d'Alba, aunque me la ha mitigado con afirmarme quedaba mejor. Dios dé a su Excelencia la salud y prosperidad que le desean los que conocen su valor y el provecho que semejantes ministros hacen en la república cristiana y la que habemos menester los suyos [...]. Héle suplicado por cierta relación importante a mi contento y a mis estudios, y no querría que disimulase mi deseo. V. $m$ me la haga de interceder y solicitar por su parte, que luego entenderá su Excelencia el sugeto que aquí no declaro. ${ }^{224}$

De nuevo, parece que Montano actúe con suma discreción y cautela. ¿¿De verdad estaría solicitando una relación necesaria para sus estudios? ¿Cuál sería el tema que deja sin declarar? El hermetismo voluntario de Montano es paradójicamente manifiesto. ¿No estaría, en realidad, solicitando a Alba noticias sobre su conflicto con el rey, enraizado en el proceso contra su hijo? Estas interrogaciones no ignoran el riesgo de su planteamiento y solo están destinadas a sugerir escenarios admisibles y no forzosamente descartables, de momento. De confirmarse algún día con nuevos datos las suposiciones propuestas, la implicación de Montano en el caso de don Fadrique, fuera de la naturaleza que fuese, podría confirmar también que tras ese incógnito amigo y servidor de Aldana se halló siempre el hijo del duque de Alba, el mismo que antes de firmar su nombre declaraba "a lo que señor mandáredes" como muestra de su incuestionable inclinación por el Divino.

Ya para finalizar, merecen una mínima atención las últimas palabras que Montano dejó escritas para Aldana. El apasionado admirador de estas dos figuras y de su verdadera y clásica amicitia lamentará la brevedad expresiva del biblista, pero no se olvide que es en esa concisión y sencillez, en ese grano de arena, donde puede verse el mundo entero. Escribió Montano: "Si la epístola e[n] verso no fuera para mí era digna de admiració[n] de todos los buenos ingenios. Sea Dios be[n]<dito por> sus dones y maravillas". Toda imaginación mínimamente embelesada podrá figurarse hoy la lectura atenta y complacida que hizo Montano de la epístola de Aldana entre los muros de El Escorial. Pese a su pro-

224. Carta de Arias Montano a Gabriel de Zayas, 13 de junio de 1578, en CODOIN, tomo XLI (1862: 367). 
verbial modestia, ${ }^{225}$ consideró los versos de su amigo dignos de los mejores ingenios. La estampa, se mire por donde se mire, es impagable. Resulta positivo descubrir, además, que Montano leyó la epístola que su gran amigo le había dedicado justo después de que el poeta la compusiera, lo que nos proporciona una imagen nítida y concreta de una circulación temprana del poema en su forma original y manuscrita. Preciso es comentar en este punto que en la biblioteca del secretario Mateo Vázquez, alumno y gran amigo de Montano desde sus años sevillanos, destacaba un manuscrito poético citado como "Francisco de Aldana y Arias Montano sobre el recogimiento del ánima escrito de mano enquadernado en pergamino". Este dato, recogido en un inventario realizado en Madrid a 17 de enero de 1579 sobre "los libros que stan en la rrecámara del so Matheo Vázquez", 226 podría dibujar un panorama de redes de amistad y patrocinio, político y también cultural, en torno a las figuras de Montano, Mateo Vázquez y Aldana, sumamente interesante. No se olvide, a este respecto, que gracias a la mediación directa del secretario del rey (animado por el duque de Alba) Aldana pudo obtener el título de castellano de la fortaleza de San Sebastián, una intercesión que tuvo lugar, curiosamente, pocos días después de que el poeta firmara su epístola, casi al mismo tiempo que redactaba su memorial para Felipe II. Este nuevo horizonte impone algunas preguntas: ¿pudo depositar el poeta algún interés personal y mundanal en su epístola espiritual a Montano? ¿Pudo buscar el poeta con la composición y envío de su epístola la influencia del biblista y de sus poderosas amistades en la corte para la obtención de sus pretensiones? Quede aquí abierto este camino para próximos estudios.

225. De la archiconocida humilitas de Montano se encuentran numerosos ejemplos en su epistolario, como este: "V. m. me había prometido excusarme del título del grado, y hase olvidado; cierto no me cuadra: que aun el de discípulo no merezco, que hasta esto hago mal, que no deprendo como debría”, carta de Arias Montano a Gabriel de Zayas, 31 de mayo de 1577, en CODOIN, tomo XLI (1862: 346-347). Sin duda, la modestia de Montano fue reconocida por sus contemporáneos y recordada por las futuras generaciones. Lope de vega, por ejemplo, como ha notado recientemente Jesús Ponce Cárdenas, evocó esa cualidad del insigne biblista en un pasaje de su Respuesta al obispo de Jaén. La remembranza no tiene desperdicio: "Pero si ya, pastor esclarecido, / os cansan estos versos, aunque a ratos / el arco aflojan, que se rompe asido, / largos los juzgaréis, pero no ingratos: / solo os diré que en Alemania dieron / a Arias Montano un libro de retratos / y que los celebrase le pidieron / en epigramas cándidos y tersos, / tan eruditos como siempre fueron. / Montano comenzó y, entre diversos / rostros hallando al vivo su retrato, / pasole en blanco y prosiguió los versos. / Pero viendo los dueños su recato, / todos le celebraron, pensamiento / que -porque lo entendéis- no le dilato", vv. 301-315, en Vega (Rimas sacras, p. 503); versos citados en Ponce Cárdenas (2018: 21-22).

226. Instituto de Valencia de Don Juan, envío 71, libro 2, ff. 22r-28r (la epístola manuscrita a Montano se cita en el f. 25r); véase también Sánchez-Molero (2014: 41 y 47). 


\section{Bibliografía}

Adriani, Giovanni Battista, Istoria de'suoi tempi, Florencia, nella Stamperia de i Giunti, 1583.

Alba, Duque de, Epistolario del III Duque de Alba Don Fernando Álvarez de Toledo. Años 1572-1581, III, Madrid, Real Academia de la Historia, 1952.

Alcalá, Ángel, "Epílogo", en Ben Rekers, Arias Montano, Madrid, Taurus, 1973, pp. 235-252.

—, "Arias Montano y el familismo flamenco: una nueva revisión”, en Anatomía del Humanismo. Benito Arias Montano 1598-1998, ed. Luis Gómez Canseco, Huelva, Servicio de Publicaciones de la Universidad de Huelva, 1998, pp. 85-109.

Aldana, Cosme de, Segunda parte de octavas, y sonetos de Cosme de Aldana, Gentilhombre entretenido de su Mag. Cath. Sobre la muerte de su hermano el capitán Francisco de Aldana, Florencia, Jorje Mariscote, 1587.

Aldana, Francisco de, Todas las obras que hasta agora se han podido hallar del Capitán Francisco de Aldana, Alcayde de San Sebastián, que fue Maestro de Campo General del Rey de Portugal en la jornada de África, a do murió peleando, Madrid, Luys Sánchez, 1593.

—, Poesías castellanas completas, ed. José Lara Garrido, Madrid, Cátedra, 1985.

Aldimari, Biagio, Memorie historiche di diverse famiglie nobili, Nápoles, nella Stamperia di Giacomo Rillard, 1691a.

—, Historia genealogica della familia Carafa, Nápoles, Antonio Bulifon, 1691b.

Alvar EzQuerra, Alfredo, "Benito Arias Montano en Portugal", en Arias Montano y su tiempo, Mérida, Editora Regional de Extremadura, 1998, pp. 191-214.

Arias Montano, Benito, Correspondencia. Tomo I (1560-1570), ed. Juan Francisco Domínguez Domínguez, Madrid, Ediciones Clásicas, 2017.

Battistini, Mario, Lettere di Giovan Battista Guicciardini a Cosimo e Francesco de' Medici scritte dal Belgio dal 1559 al 1577, Bruselas-Roma, Bibliothèque de l'Institut historique belge de Rome, 1949.

BéCares Botas, Vicente, Arias Montano y Plantino. El libro flamenco en la España de Felipe II, León, Universidad de León, Secretariado de Publicaciones, 1999.

Beck, Colette, "Hommes et culture au sein de l'Accademia dei Consufi à Anvers au xvi i siècle", en Atti del II' Congreso Internazionale di Studi Storici. Rapporti Genova-Mediterraneo-Atlantico nell'età moderna, ed. Raffaele Belvederi, Génova, Pubblicazioni dell' Istituto di Scienze Storiche-Università di Genova, 1985, pp. 213-223.

Braudel, Fernand, El Mediterráneo y el mundo mediterráneo en la época de Felipe II, II, Fondo de Cultura Económica, Ciudad de México, 2018.

Cabrera de Córdoba, Luis, Felipe II, rey de España, Madrid, Aribau y C. a, II, 1876.

Calendars of State Papers Foreign: Elizabeth, 1575-1577, XI, ed. Allan James Crosby, Londres, 1880. 
Cerrón Puga, María Luisa, "Itinerario editorial de Cosme de Aldana, 'gentilhombre entretenido de su Majestad Católica”, Studi Ispanici, XII (19871988), pp. 181-240.

Charlo Brea, Luis, "Carta inédita de B. Arias Montano a Levino Torrencio en MS. Estoc. A 902", Humanistica Lovaniensia. Journal of Neo-Latin Studies, LIII (2004), pp. 251-262.

Colección de Documentos Inéditos para la Historia de España, VII, Madrid, Imprenta de la viuda de Calero, 1845.

Colección de Documentos Inéditos para la Historia de España, XXXVII, Madrid, Imprenta de la viuda de Calero, 1860.

Colección de Documentos Inéditos para la Historia de España, XLI, Madrid, Imprenta de la viuda de Calero, 1862.

Colección de Documentos Inéditos para la Historia de España, CII, Madrid, Imprenta de Rafael Marco y Viñas, 1892.

Conde, Prudencio J., “Arias Montano y la cuestión bíblica de su tiempo", Revista del Centro de Estudios Extremeños, II, 1-2 (1928), pp. 403-498.

Conestaggio, Gerolamo de Franchi, Dell' Vnione del Regno di Portugallo alla corona di Castiglia, Génova, Girolamo Bartoli, 1585.

Correspondance du Cardinal de Granvelle, 1565-1583, V, publicada por M. Charles Piot, Bruselas, F. Bayez, imprimeur de l'Académie Royale, 1886.

Covarrubias, Sebastián de, Tesoro de la lengva castellana o española, Madrid, Luis Sánchez, 1611.

DÁvila Pérez, Antonio, "La censura erasmista en el Índice Expurgatorio de 1571 a través de los documentos de Benito Arias Montano", en Actas Congreso Internacional sobre Humanismo y Renacimiento (León, 4-8 de junio de 1996), ed. Maurilio Pérez González, I, León, Universidad de León, 1998, pp. 303-310.

—, "La polémica Arias Montano-Wilhelmus Lindanus: un nuevo documento (AGR I, 115, nr. 3714), Humanistica Lovaina, XLIX (2000), pp. 139-165.

-, Benito Arias Montano. Correspondencia conservada en el Museo Plantin-Moretus de Amberes, Alcañiz-Madrid, Consejo Superior de Investigaciones Científicas, 2002a, 2 vols.

—, "El epistolario de Benito Arias Montano: Catálogo provisional", De Gulden Passer, LXXX (2002b), pp. 63-129.

—, "Dos lecturas erróneas ("omnis familia" / "amoris familia" y "simque / sinque"). Consecuencias en la bio-bibliografía de Arias Montano (1527-1598) y de la imprenta plantiniana", Lias. Journal of Early Modern Intellectual Culture and its Sources, XXX, 2 (2003), pp. 299-309.

—, "La correspondencia inédita de Benito Arias Montano: nuevas prospecciones y estudio", en Benito Arias Montano y los humanistas de su tiempo, I, ed. José María Maestre Maestre, Eustaquio Sánchez Salor, Manuel Antonio Díaz Gito, Luis Charlo Brea y Pedro Juan Galán Sánchez, Mérida, 2006, pp. 65-78. 
—, “Regnavit a ligno Deus. Affirmat Arias Montanus; negat Lindanus'. Revisión de la polémica Benito Arias Montano-Wilhelmus Lindanus a la luz de nuevos documentos", Humanistica Lovaniensia. Journal of Neo-Latin Studies, LVIII (2009), pp. 125-189.

—, "Primeros advertimientos de Benito Arias Montano a Felipe II sobre la rebelión de Flandes", Calamvs Renascens, núm. 11 (2010), pp. 7-35.

—, "New Documents on Benito Arias Montano (ca 1525-1598) and Politics in the Netherlands", en Between Scylla and Charybdis. Learned Letter Writers Navigating the Reefs of Religious and Political Controversy in Early Modern Europe, ed. Jeanine De Landtsheer y Henk J. M. Nellen, Leiden-Boston, Brill, 2011, pp. 233-262.

-, "Correspondencia latina inédita entre Benito Arias Montano y Juan Rethio (1572-1573)”, Humanistica Lovaniensia. Journal of Neo-Latin Studies, LXIV (2015a), pp. 113-165.

-, "Pro hebraicis exemplaribus et lingua: carta Latina inédita de Benito Arias Montano a Gilberto Genebrardo (BNE, Ms. 149)", Ágora. Estudos Clássicos em Debate, XVII, 1 (2015b), pp. 337-412.

Domenichini, Daniele, "Benito Arias Montano e Italia. Dos cartas inéditas", Revista de Estudios Extremeños, XLIV, 3 (1988), pp. 565-571.

Domínguez Domínguez, Juan Francisco, "Prefacio", en Benito Arias Montano, Correspondencia. Tomo I (1560-1570), Madrid, Ediciones Clásicas, 2017, pp. 9-11.

Fernández López, Sergio, "Poesía y espiritualidad en Francisco de Aldana. A vueltas con la "Carta a Arias Montano" y más versos sacros", Studia Aurea, XII (2018), pp. 67-87.

Flórez De OCARIZ, Juan, Libro segundo de las genealogías del nvevo reyno de Granada, Madrid, por Ioseph Fernández de Buendía, 1676.

Gachard, Louis Prosper, Correspondance de Philippe II sur les affaires des PaysBas, III, Bruselas-Gante-Lepzig, C. Muquardt, 1858.

García, Miguel Ángel, "Sin que la muerte al ojo estorbo sea". Nueva lectura crítica de Francisco de Aldana, Mérida, Editora Regional de Extremadura, 2010.

García Carrafa, Alberto y Arturo, Diccionario heráldico y genealógico de apellidos españoles y americanos, IV, Madrid, Imprenta de Antonio Marzo, 1921.

Gómez Canseco, Luis, Poesía y contemplación. Las "Divinas nupcias" de Benito Arias Montano y su entorno literario, Huelva, Universidad de Huelva, 2007.

—, "Cultura y política en Flandes bajo el gobierno del Gran Duque de Alba: Benito Arias Montano", en Congreso V centenario del nacimiento del III Duque de Alba Fernando Álvarez de Toledo. Actas. Piedrahita, El Barco de Ávila y Alba de Tormes (22 a 26 de octubre de 2007), Ávila, Diputación Provincial de Ávila y Diputación Provincial de Salamanca, 2008, pp. 579-598.

-, y Valentín Nuñez Rivera, Arias Montano y el "Cantar de los Cantares", Kassel, Reichenberger, 2001.

Gómez Vozmediano, Miguel Fernando, Francisco de Rades de Andrada, cronis- 
ta y lijanista. Adiciones a la Crónica de la Orden y Caballería de Calatrava, Madrid, Consejo Superior de Investigaciones Científicas, 2016.

González Carvajal, Tomás, "Elogio histórico del Doctor Benito Arias Montano", en Memorias de la Real Academia de la Historia, VII, Madrid, Imprenta de I. Sancha, 1832, pp. 1-199.

Guicciardini, Ludovico, Descrittione di tutti i Paesi Bassi, altrimenti detti Germania inferiore. Con tutte le carte di Geographia del paese, et col ritratto naturale di molte terre principali, Amberes, Apresso Christofano Plantino, 1581. Hänsel, Sylvaine, Benito Arias Montano (1527-1598). Humanismo y arte en España, Huelva, Servicio de Publicaciones Universidad de Huelva, 1999.

Hernando Sánchez, Carlos José, "Guardar secretos y trazar fronteras: el gobierno de la imagen en la Monarquía de España”, en El dibujante ingeniero al servicio de la monarquía hispánica. Siglos XVI-XVIII, ed. Alicia Cámara Muñoz, s.l., Fundación Juanelo Turriano, 2016.

Herrera, Antonio de, Primera parte de la Historia General del Mundo, Madrid, por Luis Sánchez, 1601.

Jiménez de la Espada, Marcos, El código Ovandino, Madrid, Imprenta de Manuel G. Hernández, 1891.

Lara Garrido, José, "Introducción”, en Francisco de Aldana, Poesías castellanas completas, Madrid, Cátedra, 1985, pp. 13-114.

—, “Tratar en esto es solo a ti debido': las huellas del Dictatum Christianum en la Epistola a Arias Montano de Francisco de Aldana", en Silva. Studia philologica in honorem Isaías Lerner, ed. Isabel Lozano-Renieblas y Juan Carlos Mercado, Madrid, Castalia, 2000a, pp. 371-391.

—, “Palma de Marte' y 'lauro de Apolo': la poesía del 'oficio militar' en Francisco de Aldana y Cristóbal de Virués", en La espada y la pluma. Il mondo militare nella Lombardia spagnola cinquecentesca. Atti del Convegno Internazionale di Pavia, 16, 17, 18, ottobre 1997, Viareggio-Lucca, Mauro Baroni Editore, 2000b, pp. 281-346.

Lara Ródenas, Manuel José de, "Arias Montano en Portugal. La revisión de un tópico sobre la diplomacia secreta de Felipe II", en Anatomía del Humanismo. Benito Arias Montano 1598-1998, ed. Luis Gómez Canseco, Huelva, Servicio de Publicaciones de la Universidad de Huelva, 1998, pp. 343-366. Lazure, Guy, "Mecenazgo y clientelismo en los años sevillanos de Benito Arias Montano. Genealogía social e intelectual de un humanista", en Arias Montano y los humanistas de su tiempo, ed. José María Maestre Maestre, Eustaquio Sánchez Salor, Manuel Antonio Díaz Gito, Luis Charlo Brea y Pedro Juan Galán Sánchez, I, Mérida, 2006, pp. 111-124.

Lerner, Isaías, "Dos cartas inéditas de Benito Arias Montano en la Morgan Library and Museum", Voz y Letra, XX, 1 (2009), pp. 129-140.

Macías Rosendo, Baldomaro, La Biblia Políglota de Amberes en la correspondencia de Benito Arias Montano (Ms. Estoc. A 902), Huelva, Servicio de Publicaciones Universidad de Huelva, 1998. 
—, "La correspondencia de Arias Montano con Abraham Ortelio: nuevos testimonios de una amistad sin fronteras", La Ciudad de Dios, CCXVII, 2 (2004), pp. 551-572.

—, "El De Arcano Sermone en el marco de la Biblia Políglota de Amberes", en Benito Arias Montano, Libro de José o sobre el lenguaje arcano, ed. Luis Gómez Canseco, Fernando Navarro Antolín y Baldomero Macías Rosendo, Huelva, Servicio de Publicaciones Universidad de Huelva, 2006, pp. 21-42.

- La correspondencia de Benito Arias Montano con el Presidente de Indias Juan de Ovando, Huelva, Servicio de Publicaciones Universidad de Huelva, 2008.

Maldonado y Cocat, Ramón José, "Origen y armas del apellido Maldonado", Hidalguía, Año I, 3 (octubre-diciembre, 1953), pp. 469-480.

Maltby, William S., El Gran Duque de Alba, Girona, Atalanta, 2007.

Manegold, Cornelia, "Clementia principis. Intention und Rezeption des Standbildes für Fernando Álvarez de Toledo, Dritter Herzog von Alba (1507-1582)", en Unwissen und Missverständnisse im vormodernen Friedensprozess, ed. Martin Espenhorst, Göttingen, Vandenhoeck \& Ruprecht, 2013, pp. 41-70.

Mangas Navarro, Natalia Anaís, "La figura de Pedro de Gracia Dei: un bosquejo biográfico", Estudios Románicos, XXIX (2020a), pp. 297-318.

—, "Transmisión textual y catálogo de la obra poética de Pedro de Gracia Dei", Revista de Literatura Medieval, XXXII (2020b), pp. 191-214.

—, "El cancionero NH6 (Hispanic Society of America, ms. B2423): una fuente monográfica de Pedro de Gracia Dei”, eHumanista, XLVI (2020c), pp. $137-150$.

Martín Nieto, Dionisio Á., y Bartolomé Miranda Díaz (eds.), Noticias de Alcántara, I, Cáceres, Diputación de Cáceres, 2010.

Martínez Hernández, Santiago, "El desafío de la Casa de Toledo: Felipe II y el proceso contra don Fadrique de Toledo, IV Duque de Alba (15661585)", Mediterranea - ricerche storiche, Año X, 29 (diciembre, 2013), pp. 473-512.

Martínez López, María José, "La primera redacción de las Octavas dirigidas a Felipe II de Francisco de Aldana y su inédita dedicatoria en prosa", Criticón, núm. 70 (1997), pp. 31-70.

Mavilla, Francesca, Committenti e collezionisti tra l'Italia e le Fiandre. Il ruolo di Paolo e Chiappino Vitelli nel contesto artistico e culturale del Cinquecento, Tesis doctoral, Perugia, Università degli Studi di Perugia, 2016.

-, "'Sua signora è qua in molta buona riputatione con ciascuno'. Chiappino Vitelli e i fratelli Guicciardini”, Horti Hesperidum. Studi di storia del collezionismo e della storiografia artistica, VIII, 1 (2018), pp. 321-348.

Mendoza, Bernardino de, Comentarios de Don Bernardino de Mendoça, de lo sucedido en las Guerras de los Payses Baxos, desde el año de 1567 hasta el de 1577, Madrid, por Pedro Madrigal, 1592.

Mogrobejo, Endika, Diccionario hispanoamericano de heráldica, onomástica y genealogía, XVII (II), Bilbao, Mogrobejo-Zabala, 1998. 
Molina, Bartolomé Sagrario de, Descripción del reyno de Galicia y de las cosas notables dél, con las Armas y Blasones de los Linages de Galicia, de donde proceden señaladas Casas de Castilla, s. 1., c. 1620.

Montero Delgado, Juan, Carlos Alberto González Sánchez, Pedro Rueda Ramírez y Roberto Alonso Moral, De todos los ingenios los mejores: el Condestable Juan Fernández de Velasco y Tovar, V duque de Frías (c. 15501613), Sevilla, Real Maestranza de Caballería de Sevilla, 2014.

Morales Lara, Enrique, "Las cartas de Benito Arias Montano a Abraham Ortels: edición crítica y traducción a español", Humanistica Lovaniensia. Journal of Neo-Latin Studies, LI (2002), pp. 153-205.

-, "Otras tres cartas de Benito Arias Montano a Abraham Ortels: edición crítica y traducción a español", Humanistica Lovaniensia. Journal of Neo-Latin Studies, LIII (2004), pp. 219-249.

Morales Oliver, Luis, Arias Montano y la politica de Felipe II en Flandes, Madrid, Editorial Voluntad, 1927.

Morocho Gayo, Gaspar, "Transmisión histórica y actual del biblismo de Arias", Cuadernos de Pensamiento, núm. 12 (1998), pp. 135-240.

Nievas Rojas, Adalid, "Nuevos datos para la biografía de Francisco de Aldana. Primera etapa en Flandes (1567-1571)", Boletín de la Real Academia Española, C, 321 (2020), pp. 147-206.

Nueva Colección de Documentos Inéditos para la Historia de España, III, Madrid, Imprenta de los hijos de M. G. Hernández, 1893.

Ortega Sánchez, Delfín, "El enfrentamiento entre Arias Montano y León de Castro en la correspondencia privada del humanismo cristiano: ¿límites filológicos o divergencias humanísticas?", Revista Electrónica de Estudios Filológicos, núm. 11 (2006), en línea, <https://www.um.es/tonosdigital/znum11/ estudios/19-benito.htm>.

PaCini, Arturo, "Desde Rosas a Gaeta". La costruzione della rotta spagnola nel Mediterraneo occidentale nel secolo XVI, Milán, FrancoAngeli, 2013.

PARKer, Geoffrey, España y la rebelión de Flandes, Madrid, Editorial Nerea, 1989.

—, El ejército de Flandes y el Camino Español 1567-1659, Madrid, Alianza Editorial, 2014.

Pascal, Blaise, Pensées, ed. Louis Lafuma, París, Éditions du Seuil, 1962.

Pellicer Ossau y Tovar, José, Bibliotheca formada de los libros i obras publicas de don Ioseph Pellicer de Ossav y Tovar, Valencia, por Gerónimo Vilagrasa, 1671.

Piferrer, Francisco, Nobiliario de los reinos y señorios de España, I, Madrid, Calle del Colmillo 12, 1857.

Pintacuda, Paolo, "Aldana, Cosme de", en Diccionario filológico de literatura española. Siglo XVI, dir. Pablo Jauralde Pou, Madrid, Castalia, 2009, pp. 38-49.

Ponce Cárdenas, Jesús, "Lope de Vega y Arias Montano: ecos de los Humanae Salutis Monumenta en el Isidro", en Lope de Vega y el humanismo cristiano, ed. Jesús Ponce Cárdenas, Madrid-Fráncfort del Meno, IberoamericanaVervuert, 2018. 
Pozuelo Calero, Bartolomé, "La oda de Benito Arias Montano a Pedro Vélez de Guevara o la añoranza de la vida retirada”, Criticón, núm. 113 (2011), pp. 35-62.

Queiroz Velloso, José Maria de, Don Sebastián. 1554-1578, trad. Ramón de Garciasol, Madrid, Espasa-Calpe, 1943.

Ramos, Rafael, "Dos notas sobre la vida y la fama póstuma de Francisco de Aldana", Studia Aurea, XII (2018), pp. 127-151.

Rekers, Ben, Arias Montano, versión española y epílogo de Ángel Alcalá, Madrid, Taurus, 1973.

Rivas, duque de, Origen del apellido Maldonado, Madrid, 1874.

Rivero Rodríguez, Manuel, "La Liga Santa y la paz de Italia (1569-1576)”, en Politica, religión e inquisición en la España moderna: homenaje a Joaquin Pérez Villanuena, ed. Pablo Fernández Albadalejo, José Martínez Millán y Virgilio Pinto Crespo, Madrid, Universidad Autónoma de Madrid, 1996, pp. 587-620.

Rivers, Elias L., "Francisco de Aldana, el divino capitán", Revista de Estudios Extremeños, IX, 1-4 (1953), pp. 451-635.

—, "Introducción”, en Francisco de Aldana, Poesías, Madrid, Espasa-Calpe, 1957, pp. XI-LV.

Ruiz Silva, Carlos, Estudios sobre Francisco de Aldana, Valladolid, Universidad de Valladolid, 1981.

SÁnchez-Molero, José Luis Gonzalo, "Mateo Vázquez de Leca: un secretario entre libros. 2. La biblioteca (1)", Hispania Sacra, LXVI, Extra I (enerojunio, 2014), pp. 35-65.

Sánchez Rodríguez, Carlos, Perfil de un humanista: Benito Arias Montano, Huelva, Diputación Provincial de Huelva, 1997.

Serrano, Luciano, La Liga de Lepanto entre España, Venecia y la Santa Sede, I, Madrid, Junta para Ampliación de Estudios e Investigaciones Científicas, 1918.

Serricchio, Cristanziano, "La fabricca del Castello di Manfredonia in un libro di conti del 1507-1529", en $8^{\circ}$ Convegno Nazionale sulla Preistoria-Protostoria-Storia della Daunia, San Severo, Sales, 1998, pp. 189-241.

Sosa, Jerónimo de, Noticia de la gran casa de los marqueses de Villafranca y sv parentesco con las mayores de Evropa, Nápoles, Nouelo de Bonis, 1676.

Tellechea Idígoras, J. Ignacio, "Benito Arias Montano y San Carlos Borromeo", en Anatomía del Humanismo. Benito Arias Montano 1598-1998, ed. Luis Gómez Canseco, Huelva, Servicio de Publicaciones de la Universidad de Huelva, 1998, pp. 63-84.

Torrencio, Levino, Correspondencia con Benito Arias Montano, ed. Luis Charlo Brea, Alcañiz, Consejo Superior de Investigaciones Científicas, 2007.

Trillo, Antonio, Historia de la rebelión y guerras de Flandes, Madrid, Guillermo Drouy, 1592.

Vega, Lope de, Rimas sacras, ed. Antonio Carreño y Antonio Sánchez Jiménez, Madrid-Fráncfort del Meno, Iberoamericana-Vervuert, 2006.

Zapata, Luis, Carlo famoso, Valencia, en casa de Ioan Mey, 1566. 
